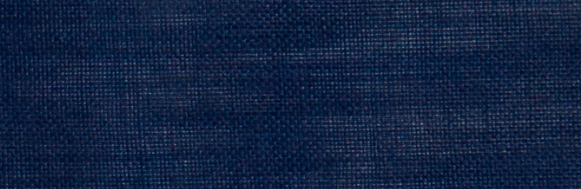

단 




\title{
Grolonical Sintruy of Uittoria.
}

\author{
OBSERVATIONS
}

ox

\section{NEW VEGETABLE FOSSILS}

OF THE

\section{AURIFEROUS DRIFTS.}

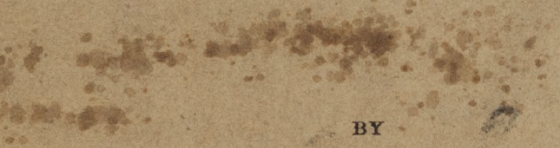

\section{BARON FERDINAND, VON MUELLER,}

C.M.G.; M.D.; Ph.D.; F.R.S. and L.S.; Government Botanist, \&zc., \&c.

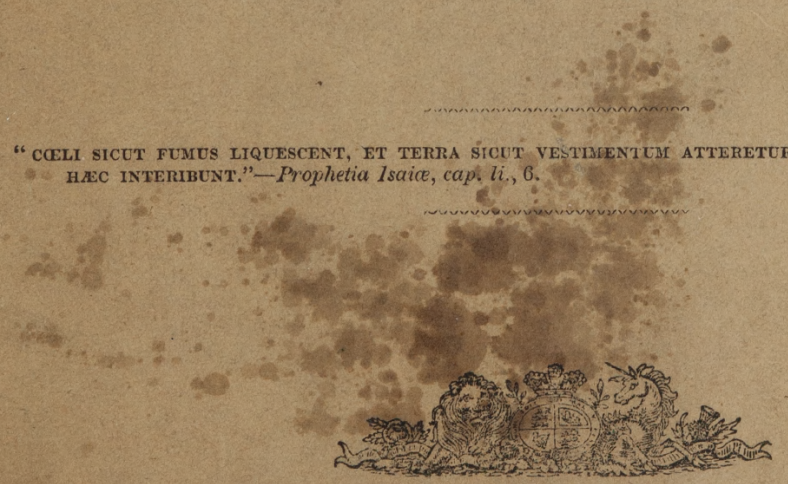

MET.BOURNE:

BY AUTHORITY : JOHN FERRES, GOVERNMENT PRINTER.

IONDON:

TRÜBNER AND CO., 57 AND 59 LCDGATE HULL.

MDCCCLXXIV

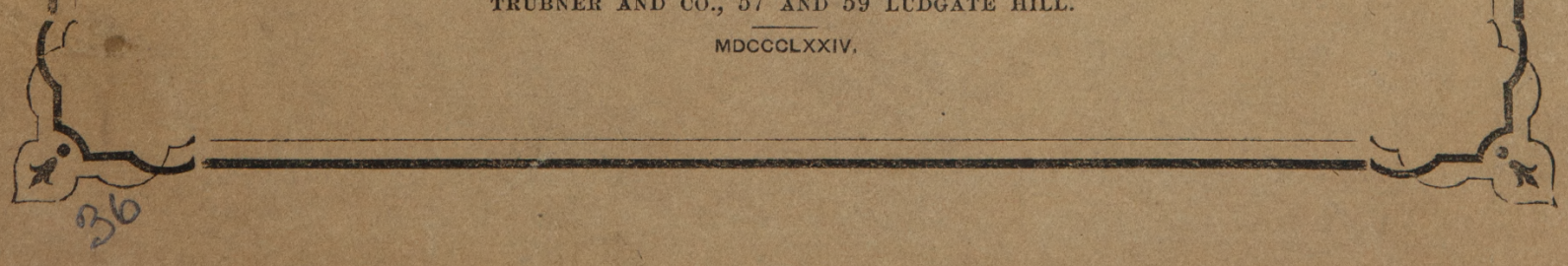





\title{
Geolonital Surrten of Hictoria.
}

\author{
OBSERVATIONS
}

on

\section{NEW VEGETABLE FOSSILS}

OF THE

\section{AURIFEROUS DRIFTS.}

BY

\section{BARON FERDINAND VON MUELLER,}

C.M.G.; M.D.; Ph.D.; F.R.S. and L.S.; Government Botanist, \&c., \&c.

MELBOURNE:

BY AUTHORITY : JOHN FERRES, GOVERNMENT PRINTER.

IONDON :

TRÜBNER AND CO., 57 AND 59 LCDGATE HILI.

MDCCCLXXIV. 



\section{Office of Mines, \\ Melbourne, 1st October 1874.}

Sir,

I have the honor to submit the Observations of Baron von Mueller, C.M.G., on the New Vegetable Fossils found in the deep auriferous drifts, together with plates, maps, and sections, and notes on the geology of the localities where the fossils were obtained.

I have the honor to be,

Sir,

Your most obedient Servant,

R. BROUGH SMYTH,

Secretary for Mines.

The Honorable Angus Mackay, M.P.,

Minister of Mines, \&c., \&c., \&c. 



\section{NOT E.}

When the deep leads at Ballarat, Creswick, Raglan, and Ararat, were first explored, the miners were surprised to find in the darkblue and black clays overlying the auriferous drifts, large trees, some in such perfect preservation as to admit of the wood being converted to use. The surface of the trunks was invariably carbonized, and the interior much riven, and in the fissures and interstices were found nests of auriferous iron pyrites.

Cones of Banksias, not differing carpologically from those of some of the living honeysuckle trees, were collected about twenty years ago in the older drifts of Creswick, and being examined, at the request of the late Sir Roderick Murchison, by the illustrious botanist, the late Robert Brown, were identified as such by him.*

Similar cones have since been obtained by Mr. Arrowsmith from the leads at Beechworth and Chiltern. At depths varying from 100 feet to 400 feet, vegetable fossils of the like kind occur; and the Department of Mines, through its officers, and with the friendly co-operation of mining managers and miners, has accumulated much material for the palæontologist.

In the Exchequer Claim at Daylesford, there is a stratum of hard black mud or clay in thin layers, enclosing fossil leaves of some species of eucalyptus. These leaves still preserve their fragrance, and if slightly rubbed with the finger the distinctive odour of the eucalyptus is at once perceptible.

Nearly all the fossils of this character were, from time to time, submitted to Baron von Mueller for examination; but, in consequence of the absence of eucalyptus fruit, the identification or definition of the species was difficult, if not impossible. 
Baron von Mueller constantly urged the necessity of a careful examination of the clays of the deep leads, in the hope that some fruits or seeds would be discovered; and the officers of the Department were consequently active in procuring specimens of all kinds. It was not, however, until I learnt from the late Mr. Greer, that fossil fruits had been obtained from the deep leads of the Haddon district, that any really valuable vegetable fossils were brought to light. Through his kind intervention a good collection was made, and subsequently Mr. John Lynch, and the mining managers and miners at Haddon, have added largely to it.

The account which follows of the vegetation of the period when our older auriferous drifts were deposited is singularly interesting, and now we have to record the fact that the genera and species of plants first discovered at Haddon had a very wide range.

Mr. J. S. Thomas, of Orange, in New South Wales, was good enough to send me, in reply to a request made to him, a collection of fossil fruits from the leads of that district; and immediately following this came a collection of similar fruits from Tanjil, in Gippsland. The same fossils occur also plentifully in the leads near Beechworth; and to the zeal in the cause of science of Mr. R. Arrowsmith, the Department is indebted for many specimens in excellent preservation.

The value to science of the determinations of Baron von Mueller, the high importance to the geological enquirer of the results as given by him, and the great interest evinced by scientific men in Europe, and in other parts of the world, in these researches, have led me to submit in this form the first ten plates, and his descriptions, together with some special reports. The Geological Survey may be congratulated on having the cordial co-operation of a gentleman so eminent in science. He has superintended the preparation of the plates-admirably drawn by Mr. R. Shepherd-and written the descriptions in his leisure hours-extra work altogether outside of his labors as Government Botanist.

Melbourne, 1st October 1874. 


\title{
OBSERVATIONS
}

ON THE

\section{NEW VEGETABLE FOSSILS OF THE AURIFEROUS DRIFIS,}

\author{
By BARON FERD. VON MUELLER, \\ C.M.G., M.D., Ph.D., F.R.S.; Government Botanist for Victoria.
}

Among a number of vegetable fossils, discovered not long ago in the clays of the leads at Haddon (as shown in the accompanying plan and sections), and submitted to me for phytographic examination, the fruits of a coniferous genus, allied to Cupressinites of Bowerbank, seemed the most remarkable; hence this particular fossil has been selected as the first for elucidation on the present occasion. Some preliminary remarks on the discovery of these and some other fossil fruits were, by R. Brough Smyth, Esq., the Secretary of the Victorian Mining Department, and the writer, communicated to the Geological Society of London (see Geo. Mag., page 390,1870$)$, and through those remarks the genus Spondylostrobus became established. The additional gain of more material from the place of discovery has not materially altered or enlarged the views which I entertained of the relationship of this genus, and I therefore now proceed to offer its full diagnosis. 


\section{SPONDYLOSTROBUS.}

Strobilus woody, globose-ovate or almost spherical, with five, rarely four or six, thick longitudinal ribs, forming as many blunt prominent dissepiments, consolidated in the axis of the fruit; these costr at the vertex furrowed by single grooves. Base of the strobilus naked. Valves five, rarely four or six, interjacent to the costæ, and by them widely separated from each other, erect, long appressed, fixed at the base, compressed-trigonous, the exterior face in outline oblong or lanceolar-oval, all nearly equal in size, and extending from the base of the fruit to about three-fourths its height, irregularly rough at the back, not keeled nor appendiculate. Cells five, rarely four or six, each bearing a single seed towards the centre of the fruit. Seed ovate, nearly half as long as the valves, very convex at the inner side, winged around the whole margin, pendent from near the apex of the cavity, to which it is affixed, not always all developed.

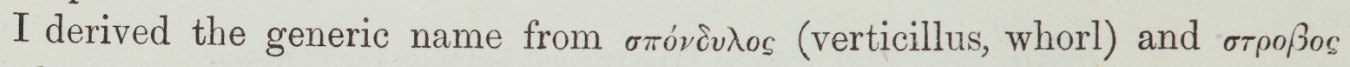
(strobus, pine-cone).

\section{Spondylostrobus Syythit.}

The only species hitherto discovered I have dedicated to the gentleman who, as Secretary of our Mining Department for many years, has so widely augmented our knowledge of the mineral resources of our adopted country, and to whose consideration I owe the opportunity of glancing over the vegetable remnants referred to in these pages.

All the specimens, well illustrated by Major Shepherd on the accompanying page, seem to belong to one single species, variable in size and shape, but connected by intermediate forms. The leaves and amenta of the tree or shrub, which furnished these fruits, remain as yet completely unknown. The smallest fruits before me measure about two-thirds of an inch, the largest one inch and two-thirds. The ridges more attenuated and convex towards the base, wider and confluent at the summit. The wings of the seeds appear slightly outward directed, not exactly peripherical. The seed is perfectly free from the valve.

The validity of the genus rests chiefly on the extraordinary development of the columella, if so it may be called; this columellar portion forming indeed the main body of the fruit. In this respect Spondylostrobus differs from all other cupressineous genera, living as well as bygone. It shares the normally five-valved structure of the fruit only with Solenostrobus (Endlicher, synopsis Coniferarum, page 272, Cupressinites, Bowerbank, London Clay partly), but, as explained already in the diagnosis, this character of the number of valves is not absolute, though predominent, and thus vindicating the generic value of Solenostrobus. The species of the latter genus are, however, very distinct from Spondylostrobus, should even the augmentation of material from new sources induce us hereafter to unite generically the new fossil now reviewed with Solenostrobus. Access to Bower- 


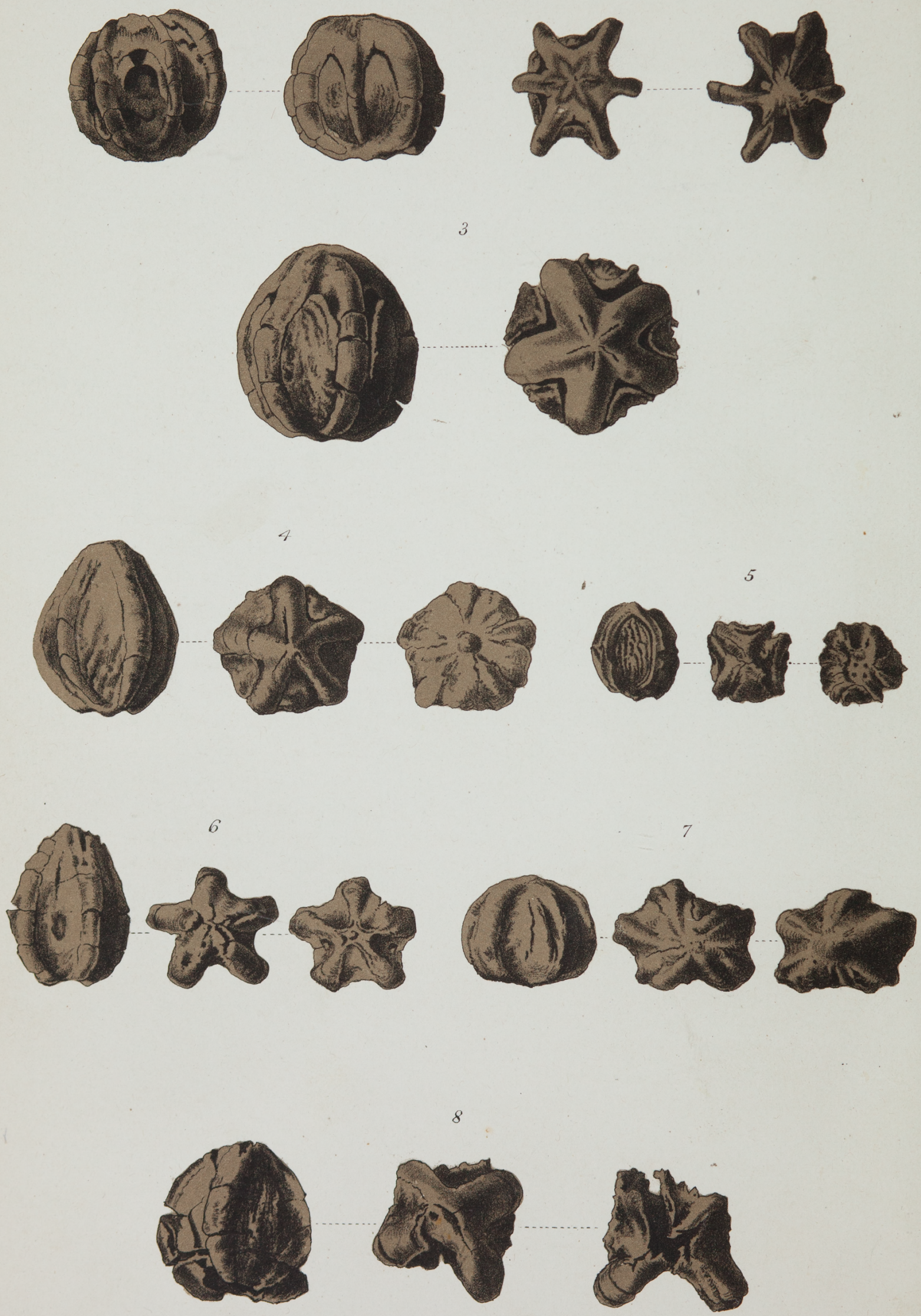
bank's illustrated work (History of the Fossil Fruits and Seeds of the London Clay, 1840), obligingly afforded me by my renerable friend, the Rev. W. B. Clarke, the senior of Australian philosophers, proved beyond doubt that the enormous columellar receptacle of Spondylostrobus, on which the valves are sunk, is totally wanting in any of the four species of Solenostrobus figured. (Plate Ix., figs. 22 and 23 ; also, plate x., figs. 24 and 25 ; also, figs. 28 and 29.) These illustrations indeed show sufficiently, that the margins of the fruit valves are contiguous, precisely as in the existing genus Callitris, and its sub-genera Frenela, Actinostrobus and Octoclinis ; whereas in Spondylostrobus the fruit valves are rendered discontiguous by the intervening and protruding ridges of the receptacle. Excellent as Sowerby's drawings are, as furnished for Bowerbank's work, they give us no insight into the real inner structure of Solenostrobus, owing indeed to the scanty or imperfectly preserved material, not sufficient for examination, or too precious to be sacrificed in dissection. Another allied genus, Passalostrobus (Endl. sỳn. Conif. 278; Cupressinites tesselatus, Bowerb. Lond. Clay, page 53, plate x., figs. 26, 27, 30, 31), may perhaps indicate in its structure an approach to a columnar development beyond the summit, but not beyond the margins of the valves, should the central portion of the fruit be receptacular and not valvular. This the re-inspection of the original specimens can only explain. The doubts entertained by the learned Schimper in reference to the systematic position of Solenostrobus (Conf. Schimper traite de paléontologie végétale, tome seconde, 1870, page 358), are, by the discovery of our pentamerous conifer in Australia, now completely cleared away. Neither in his work, nor in Heer's still more recent elucidation of some fossil coniferæ (Philos. Transactions of the Royal Society of London, 1870 , page 463, plate XLI, figs. 10 and 11 ; also, plate XLIIr., figs. 4 and 5), are any additional plants recorded, to shed light on the pentamerous coniferæ from Sheppey, as regards their foliage and seeds.

In reference to the affinity of Spondylostrobus to existing coniferous plants, a comparison is possible only with Callitris and its sub-genera, because they alone exhibit likewise a simple verticillus of fruit valves. In all the species of that genus, the columella is comparatively small or obliterated, and therefore no obstacle offered to the contiguity of their fruit valves. The seeds, moreover, are never in number less than two located at each valve, often more in number, sometimes numerous, while the valves are four, six, or rarely eight in normal number, never five. Absence of flowers, leaves, and perfect seeds of Spondylostrobus prevent us from carrying the comparison further. There is no other genus, recorded in the recent elaborate essay on existing coniferæ of the whole globe, as furnished by my illustrious friend, Professor Parlatore, for De Candolle's prodromus (pars xvi., $361-521$ ), that could be regarded closely related to the fossil plant here under consideration.

Explanation of the Limhogram.

Plate I.-Fig. 1, a spherical fruit, of ordinary size, the valves removed to bring the seeds in view. Fig. 2, a fruit with dissepimental ridges, more than usually protruding, and with six valves and six septa; the summit and base in view. Fig. 3, side view and front view of a fruit of the larger variety, the commencing expansion of the valves discernible. Fig. 4, a more ovate fruit, presenting the side, vertex and base. Fig. 5 , a small form of the fruit, moreover only four-valved, the edges of the dissepimental protrusions accidentally channelled by corrosion. Fig. 6, a fruit of almost oval shape, the side, top and base in view. Fig. 7, a fruit of depressed spherical outline. Fig. 8 , fruits in a less perfect, state of preservation. All the figures of
natural size. 


\section{PHYMATOCARYON.}

Fruit spherical, very rarely oval; outer pericarp thick, hard, externally smooth, adhering closely to the putaminous part of the fruit. Putamen capsular, three-celled or rarely two-celled, loculicidal three-valved or rarely twovalved; the valves completely separating to the base, in a dry state almost bony, externally very rough and deeply wrinkled from verrucular more or less confluent protuberances, not rarely somewhat protracted at the base. Septa usually not all well developed. One or two of the cells frequently empty. Seeds solitary in the cells, oblique ovate, turgid, rarely somewhat spherical, fixed to the summit of the cavity, pendent from the axis of the capsule. Testa smooth, thin, brittle.

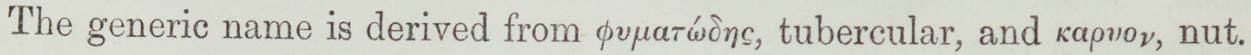

Were I to hazard an opinion on the systematic relationship of this extinct genus, I should place it with Sapindaceæ. Among living genera of "that order the pendent position of the seeds occurs also in Hypelate and Doratoxylon; the dehiscence of the fruit agrees with Cupania and several other sapindaceous genera ; the tubercular roughness occurs also in Mildea, Capura, Xerospermum, Euphoria and Nephelium, while a distinct sarcocarp and putamen are found likewise in Melicocca and Lepisanthes.

Among fossil genera Phymatocaryon comes nearest to Cupanoides, Tricarpellites and Wetherellia (Bowerbank, Fossil Fruits and Seeds of the London Clay, pages 65-90, tab. xi. and xii.) The latter genus differs in the presence of a sac-like aril and septicidal dehiscence, but agrees with our genus in pendent seeds, if I rely on Bowerbank's apparently very accurate observations, no original material for re-examination or comparison being here locally available ; yet it seems not impossible, that also in Wetherellia the more pointed or attenuated extremity represents the base of the fruit; if so the seeds would be erect. Tricarpellites, like Wetherellia, differs in dehiscence through the septa, and apparently also in wanting any separate outer fruit layer, besides in having erect seeds. The genus Cupanoides, whose number of species are evidently overrated, recedes from Phymatncaryon again in absence of a distinct thick outer pericarp, as also in erect seeds, while in size and shape the various forms of Cupanoides correspond well with such specimens of Phymatocaryon as have lost their sarcocarp. Further comparisons must be instituted from more perfect material, as only in a solitary instance the position and mode of attachment of the seeds of our fossil could be ascertained, whereas single observations on vegetable remnants like these are apt to lead to misconjecture. A secondary character, by which the new genus here described may at once be distinguished from any species of the three above named genera, consists in the remarkably 
strong rugosity and warty roughness of the dorsal part of the fruit valves, although to this characteristic a slight approach is offered by Carpellites rugosus (Bowerb., 1. c., pl. xi., figs. 41-44) and by Cupanoides tumidus (Bowerb., l. c., pl. xi., figs. 13-17). Not too much stress, however, must be laid on the occurrence of an additional outer coating of the fruit observed in Phymatocaryon, inasmuch as this crust was preserved only in two fruits among the considerable number of specimens which came under my examination; and even in these two cases the outer pericarp existed only fragmentary, to so small an extent indeed, that I should not have expected its existence in the absence of these two more perfect samples. This sarcocarp, if I have rightly recognised it, is evidently of a more perishable nature than the valves, and must have been in a recent state coriaceous or perhaps even succulent. Possibly it may yet be discovered in allied genera.

\section{Phymatocaryon Mackayi.}

In auriferous drift of the older pliocene formation on Smythe's Creek, of Haddon goldfield, at a depth of about 150 feet. J. Lynch, Esq.

I dedicate this remarkable vestige of a plant, which probably formed a prominent feature in our forests of a former age, to the Honorable Angus Mackay, M.L.A., under whose ministerial administration of the Mining Department the discovery of this and many other fossils was effected, and under whose enlightened sanction a commencement was made in the elucidation of these particular relics of a vegetation rejoicing in a milder clime, and displaying forms of tropical grandeur now foreign to the spot.

The specimens of this fossil and others alluded to in this brief essay, as well as some more, which successively are to appear in our mining records, were obligingly placed at my disposal for examination by R. Brough Smyth, Esq., F.G.S., the Secretary of the Department of Mines of Victoria.

The illustration from the skilful hand of Major Shepherd renders a detailed description unnecessary. The fruits are sometimes vertically depressed, sometimes laterally compressed. The outer pericarp, which, in its dry state, becomes almost lignescent, is of about $1 \frac{1}{2}$ line thickness ; the dehiscence of the inner valvular part of the fruit takes place from the summit downwards. The thickness of the valves, according to the size of the fruit, which, in this respect, is as inconstant as that of Wetherellia variabilis, varies from $1-2 \frac{1}{2}$ lines. The septum extends along the middle of the valves or is pushed out of the median line by the growth of the seed in the adjoining cell, or becomes obliterated; the septa meet in the axis of the fruit, but no columella remains after their separation. Very frequently only one seed is developed ; the largest, measured by me, was nearly 5 lines long, but in small fruits the seeds attain not half that size; at the spot of attachment they are pointed. The seeds fill the cavity, and must thus have been devoid of any conspicuous aril, for which evidently no space was left in the cell. In some instances, when none of the seeds became well developed, the dissepiments are found to be enlarged and consolidated with the valves into an equable mass, so much so, that the septa, by becoming 
contiguous, give to the dehiscence a septicidal appearance. The inner structure of the seeds remains unascertained, they having hardened into iron pyrites and thus been rendered amorphous. Stem, leaves, and flowers of this bygone tree remain unknown.

\section{Explanation of Lithogram.}

Plate II.

Phymatocaryon Mackayi.-Fig. 1, lateral view of two empty valves of a large trilocular fruit. Fig. 2, fruit of middle size, presenting the side summit and base; one of the valves shown separately. Fig. 3, a larger fruit, and its three valves disconnected. Fig. 4, a fruit with a portion of the outer adhering pericarp yet preserved. Fig. 5, fruit presenting its summit and side, also the cavities of its three separate valves; the cells of unequal size. Fig. 6, fruit exhibiting its vertex and side and its valves, the latter in part transversely fractured; also two separate seeds. Fig. 7, views of a seed of large size, perfect in form. Fig. 8, two valves of a small three celled fruit, one seed preserved in its natural position. Fig. 9, single valves of a small two-celled fruit, each containing a perfect seed. Fig. 10, fruit somewhat deformed, without fully distinct valvular dehiscence. Ifig. 11, a small less warty fruit, remarkably depressed, presenting summit, base and side. Fig. 12, a small almost oval fruit, the summit and side shown. Fig. 13, the valves of a two-celled fruit, one cavity larger than the other. Fig. 14, a smaller two-valved fruit. Fig. 15, a fruit of minute size.

\section{TREMATOCARYON.}

Fruit globular, bony, one-celled, one-seeded, from the vertex bursting about half downward into two valves, outside irregularly and longitudinally but only faintly furrowed, at the base deeply perforated by an oval aperture; the latter divided by a strong somewhat attenuated dissepiment into two spurious narrow basal cells, not communicating with the main cavity of the fruit. Cavity depressed-spherical, with an ample round cicatrix occupying its lower part and indicating the position of a solitary seed, attached with much of its lower half to the basal part of the cavity. Testa membraneous, smooth, shining.

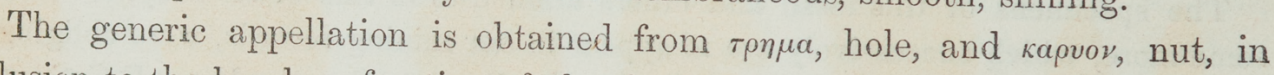
allusion to the basal perforation of the fruit.

In the short memoir, which appeared in the Geological Magazine of 1870 , page 390, I assigned, from a solitary fruit, to this fossil a position among Verbenaceæ, not wishing to sacrifice the only specimen, then available, in analysis. A few other fruits of the same species have since been found, enabling me to give the above generic account, though yet so imperfect. My original view on the affinity of Trematocaryon continues undisproved; but the inspection of the inner structure of the fruit reveals in the broadly sessile seeds a character which appears to point to Sapindaceæ, and seems to indicate the very wide hilum of Sapindus, Cupania, Nephelium, and numerous genera closely allied to them. No genus, however; of the latter order comes near to ours, while the basal openings of the fruit certainly remind of some Verbenacex, such as Cornutia, Petitia, Lantana, Gmelina, Premna, Pityrodia, Casselia, Citharexylum and Newcastlia, although it must be admitted, that the basal intrusion is not analagous in all these cases. But I am not acquainted with any genus among living or fossil plants to which Trematocaryon bears any very close alliance, 

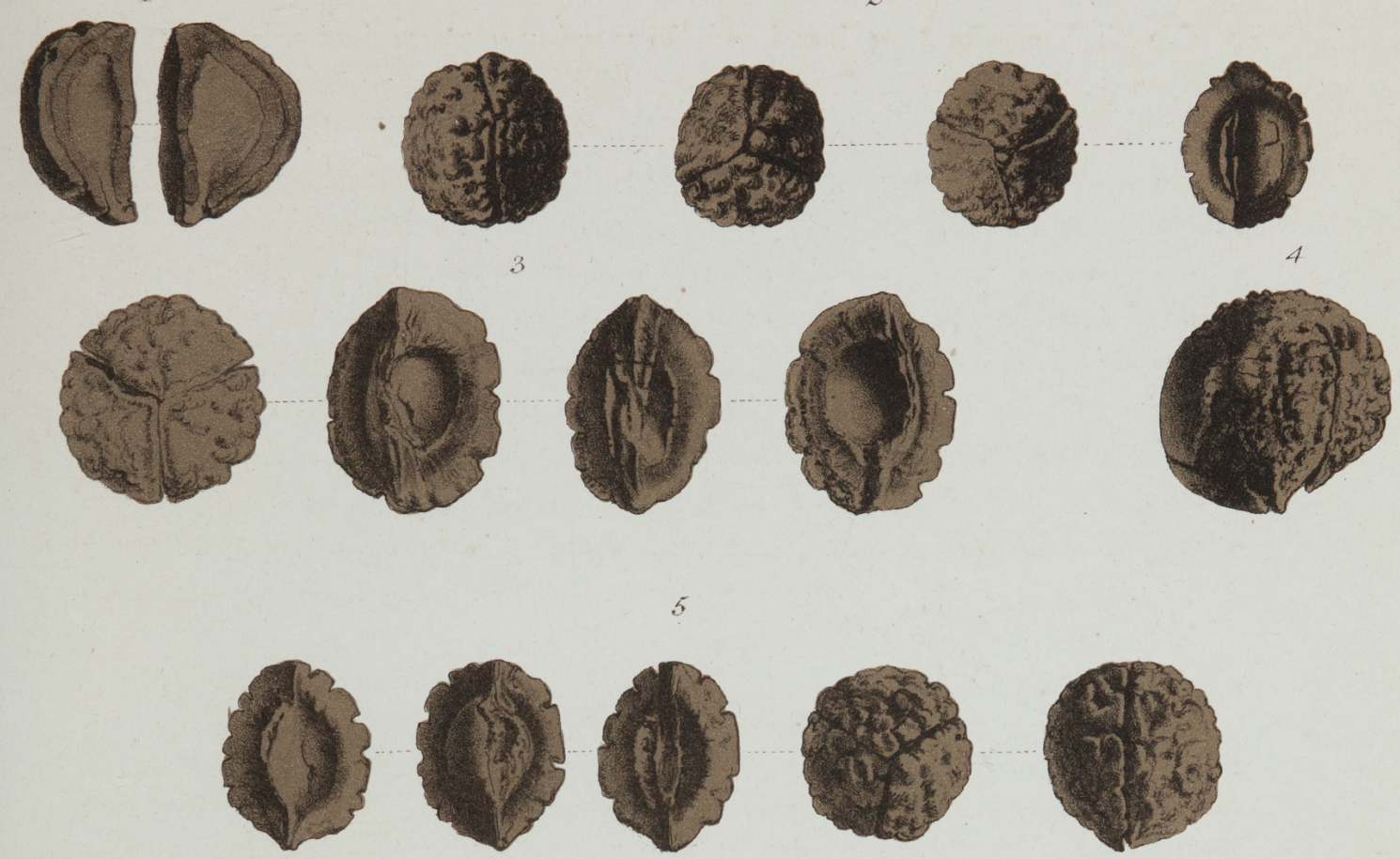

10106

10000
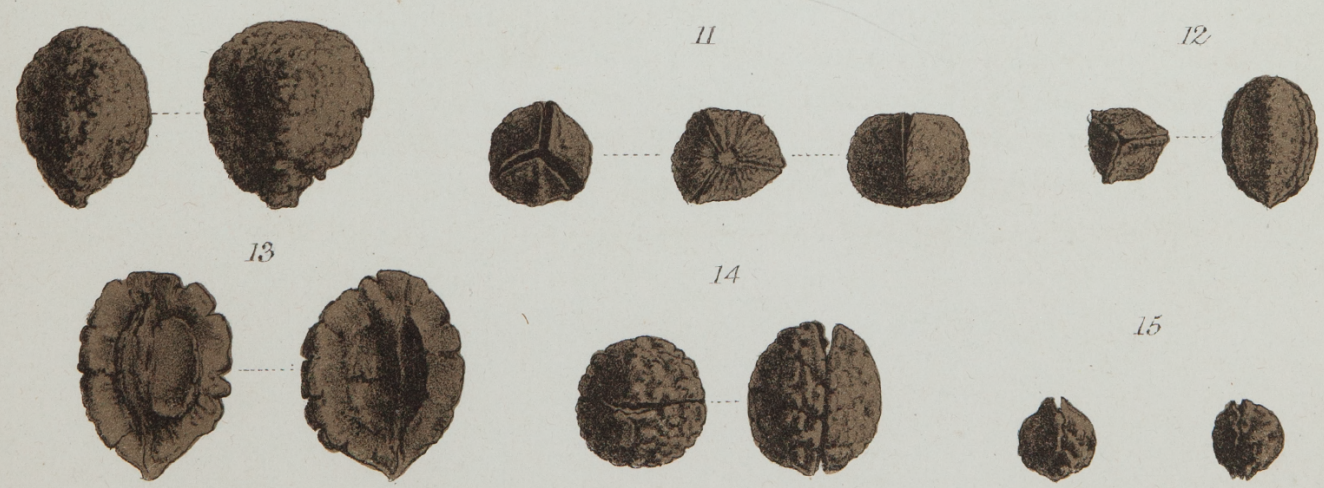




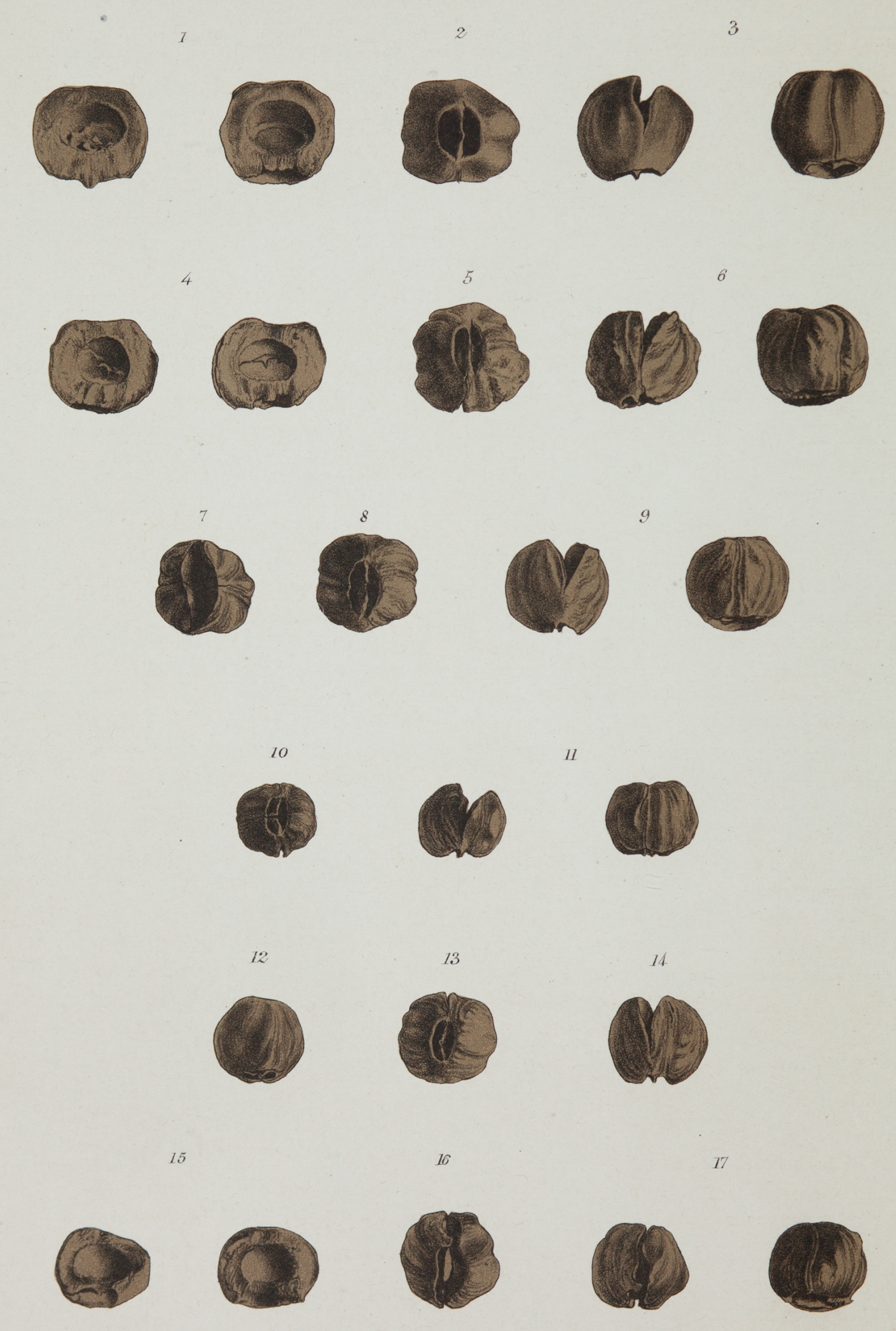


and thus its systematic position remains to me obscure, although I endeavoured, from our yet extremely limited knowledge of this bygone plant, to indicate some of its possible affinities. It is scarcely necessary to repeat also, on this occasion, that palæontologic writings like these are offered more with a view of bringing strange remnants of animal or vegetable life to notice for further searches, or for ampler comparison, or for the recognition of the ages of geologic formations, than to venture a full opinion on their definite alliance, or to come at once, or perhaps ever, to final conclusions as to their absolute affinity. Yet remarks on new scientific material, however fragmentary, may help also to indigitate the path of further enquiry; or, by drawing attention to the incompleteness of our knowledge in instances of this kind, we may secure from circumspect observers, who are placed favorably, that additional material, which may give us an insight into circumstances, which may prove of unforeseen significance.

\section{Trematocaryon MeLellani.}

In auriferous drift of the older pliocene formation of Haddon goldfield, at Nintingbool, about 150 feet below the surface. J. Lynch, Esq.

The only species of Trematocaryon is dedicated to the Honorable William MeLellan, M.L.A., for several years Minister of the Mining Department, under whose authority this unpretensive essay has passed to publicity. This dedication is also intended as a public mark of recognition of the support, which this respected gentleman in his legislative position has always accorded to the labours of the writer.

Beyond the portions of the fruit described and illustrated, nothing of the plant is known; it is likely that the fruit was yielded by a tree or large shrubby plant. The dehiscence of the capsule is not along a well indicated suture; hence the edges of the valves are uneven. The cavity is invested with a fulvous membrane, broadly adnate at the base, and representing, as far as can be judged, the testa and not an arillar appendage.

\section{Explanation of Lithogram.}

\section{Plate III.}

Trematocaryon Molellant.-Figs. 1, 4, and 15 , fruit laid open, showing the remnants of the testa, also the broad basal cicatrix, to which the seed was fixed. Higs. 2, 5, 8, 10 and 13 , various specimens of the fruit, showing its base. Figs. $3,6,9,11,12,14$, and 17, side view of various specimens of the fruit, in their erect position. Figs. 7 and 16 , fruits showing their vertex.

All the figures are indicating natural dimensions.

My illustrious friend, Professor McCoy, who kindly inspected these fossils, concurs in my opinion, that they represent forms previously undiscovered; and I feel honored, that so learned a palacontologist, who studied for many years here and in Europe the organic relics of bygone ages, has conceded to me the privi- 
lege of examining such other species of Victorian fossil plants, as stand in close relationship to existing vegetation. I fully agree with Professor McCoy, that on mere fragments of leaves, or on other most imperfect or ambiguous material, no generic nor even ordinal characteristics should be founded; and I believe that the true purposes of science in instances of this kind are served by illustrating such relics simply by drawings left unnamed, inasmuch as records thus limited will be quite sufficient, until the occasion may arise for securing to the respective species safe positions. But if any knowledge which I may possess of the vegetable life of the existing creation can aid in restoring from scattered fragments specific forms, as zoologic science has often so lucidly done from the mere fragments of bones, then I shall gladly share here in such a task, alike important and honorable.

\section{RHYTIDOTHECA.}

Capsule woody, elongated pentagonous-ellipsoid, very gradually attenuated towards the acute apex, less pointed towards the base, by loculicidal dehiscence completely dissolving into five solid valves; the latter wrinkled and rough at their dorsal portion; a slight furrow along their internal edge. Columella or free central axis absent. Seeds turgid, solitary in each cell or perhaps two superposed, only in part coming to full development, lodged either slightly below the middle of the valves or at within one-third of the summit of the capsule, but seemingly only in the former case advancing to maturity. Above and below the well defined oval cavity, formed for the reception of the nucleus-portion of the seed, are impressions indicating a prolongation of the seed upwards and downward into some long and narrow probably wing-like appendicular organ, of which, however, in the specimens, hitherto found, no traces are left. The seeds were only seen in a rudimentary state; thus their point of attachment could not be ascertained with positive accuracy.

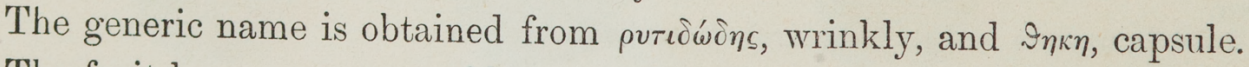

The fruit bears some resemblance to that of Flindersia Strzeleckiana (F. M. Fragm. Phytogr. Austr. i. 65), but this similarity is an external one mainly. Rhytidotheca is in reality more closely allied to the genus Chloroxylon (the only species of which yielding the beautiful East Indian satinwond, commercially and industrially so well known). The absence as well of a free central axis as of laminar placentæ and the loculicidal dehiscence bring our 


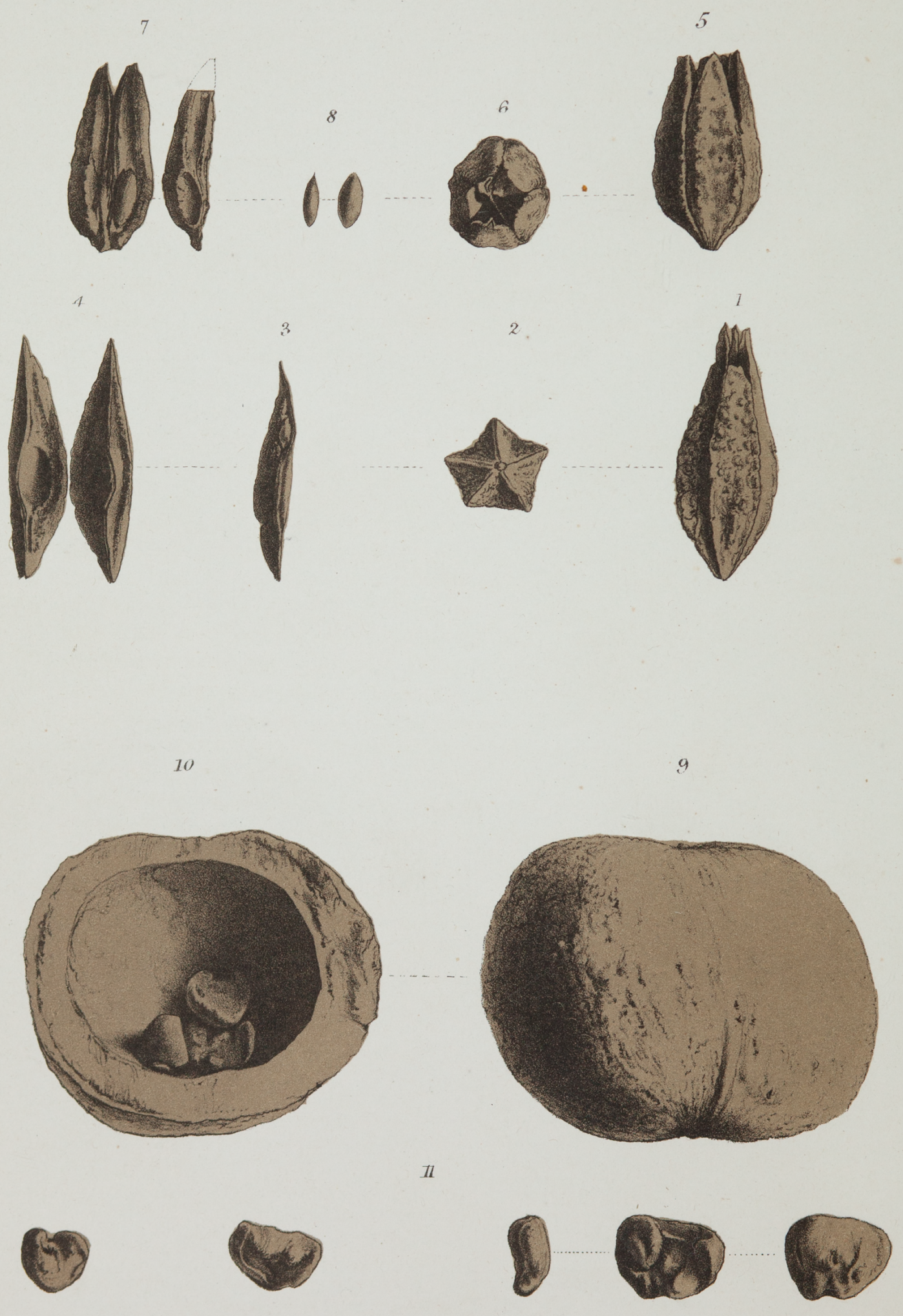
fossil nearer to Chloroxylon, while the division of the capsule into five valves indicates an approach to Flindersia. In the turgidity of the seeds Rhytidotheca differs from both, and besides in the paucity of seeds from Chloroxylon. Moreover the capsules of the various Flindersiæ are more or less echinulatetubercular, while the capsule of Choroxylon is smooth; again the verrucular prominences of Rhytidotheca are so slight as to render the capsule hardly more than rugose. What relation the foliage and flowers may have had to the above mentioned existing Meliaceous trees is entirely involved in obscurity. How far again an alliance to Sapindaceæ or some other orders with woody valvular fruit can be traced out, future researches from more enriched material must demonstrate; but in any comparisons with Sapindaceæ the number of fruit-valves, increased to five, remains exceptional.

\section{Rhyтidotheca Lynchi.}

In the auriferous deposits of the older pliocene formation of the goldfields of Haddon, at Nintingbool, about 150 feet below the surface. J. Lynch, Esq.

This fossil is dedicated to the officer, who by successful and strenuous exertions secured this species and many other palæontologic remains, which are under progress of elucidation for the valuable documents of the Mining Department, periodically issued by R. Brough Smyth, Esq.

It may be worthy of remark, that no member of the Meliaceous order exists any more in the living vegetation of our colonial territory. This newly discovered remnant of a past flora again indicates a clime formerly warmer and more humid and equable than that of the spot where now these vestiges of extinct forests are buried.

From the same locality, in which the adopted normal form was found, we possess an allied fossil, which probably constitutes merely a variety of the species above defined; the outer rugosity of the fruit is less manifest, and the nucleus of the seed is lodged at the base of the cell or near the base ; thus necessarily the space for the expansion of the wing exists only upwards, and this, as indicated by the impression, forms a terminal gradually narrowed appendage fully twice as long as the seed. The nucleus is ellipsoid and nearly 3 lines long. The collection contains also what appears to be another variety of the same species, the form of the capsule being more ovate and the diameter rather more than half the length of the fruit.

\section{Explanation of Lithogram.}

\section{Plate IV.}

Rhytidotheca Lrnchi.-Fig. 1, the capsule unopened; side view. Fig 2, the same, presenting the base. Figs. 3 and 4 , three valves, separated, showing the cavities for the reception of the seeds. Fig 5, the unopened capsule of the variety with basal seed; side view. Fig 6, the same, presenting its summit. Fig. 7, three ralves of the same, separated. Fig. 8, detached seeds, their form restored from fragments. 


\section{PLESIOCAPPARIS.}

Fruit depressed-globular, one-celled, indehiscent, slightly oblique, somewhat rough outside. Pericarp crustaceous-woody, rather smooth inside. Cavity ample, traversed on two sides, but there from the base to near the summit, by the remnants of slightly spreading placentas. Seeds several, probably numerous, more or less heart-shaped or renate, somewhat twisted, convex and rather smooth on one side, on the other face bearing irregular impressions.

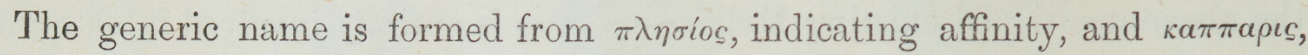
the Caper-bush, in allusion to the resemblance of this fossil to the large fruits of some species of Capparis of the Busbeckia section. In selecting the generic designation I did not wish to indicate thereby the real affinity of this genus, which remains dubious, although the form of the fruit and the shape of the seeds seem to point, perhaps deceptively, in the direction of Capparis.

\section{Plesiocapparis prisca.}

From the Haddon lead, with Spondylostrobus, Phymatocaryon, Trematocaryon and Rhytidotheca. John Lynch, Esq.; communicated by R. Brough Smyth, Esq., F.G.S.

The fruit is fully 2 inches in diameter. The pericarp has a thickness from 3 to 4 lines, and is hard, almost bony. The seeds measure from $\frac{1}{3}$ to $\frac{1}{2}$ inch. Three were found in the solitary fruit which I opened, but besides there existed some undeveloped ovules with these seeds. The cavity is slightly invested with the residue of a probably pulpy mass, which became indurated into thin lamellar strata. The structure of the embryo can no longer be ascertained, it having become by fossilification homogeneous, but appears from the shape of the seeds to have been twisted or coiled. The placentas, as indicated by a band of somewhat ramified cicatrices, stretch from the base in two lines towards the summit, apparently in a similar manner to that of Capparis Mitchelli, which shows also two placental cicatrices stretching along the walls of the pericarp nearly from the top to the bottom, as observable after the removal of the pulp.

If at all a comparison with any Capparis should be admissible, then it would be with the already mentioned large-fruited Capparis Mitchelli (Lindl. in Mitchell's Three Expeditions, i. 315), a desert tree, extending from the Murray-River nearly to Carpentaria and Arnhem's Land. On the inspection of the plate in my work on the Plants Indigenous to Victoria, Suppl. Pl. iv., it will be found, that the pericarp of Plesiocapparis is considerably thicker and that the seeds are larger and less regularly cordate-renate. Flowers and leaves of this fossil remain unknown, and thus the comparison cannot be carried further, at least for the present.

\section{Explanation of Lithogram.}

Plate IV.

Plestocapparis PRISCA.-Fig. 9, fruit unopened, like the rest of the figures given in natural size. Fig 10, fruit laid open, loose seeds within. Fig. 11, seeds, the three connected figures illustrating the same seed seen from different sides. 


\section{CELYPHINA.}

Fruit roundish or ovate, indehiscent, somewhat oblique, as a rule considerably compressed, one-celled. Pericarp thick, woody-crustaceous, outside almost even or only faintly rough, inside smooth. Perfect seeds unknown, but probably solitary and filling the cavity.

The generic name is derived from $\kappa \varepsilon \lambda \dot{u} \phi i v o s$, putaminosus, and chosen to indicate the thick and hard nutshell or pericarp, which characterizes this fossil.

So far as the scanty vestiges of the plant, designated now by the above appellation, allow us to judge, we may assume that it belonged to the order of Proteaceæ; if this view of its alliance can be adopted and sustained, it must be placed next to Helicia, a genus of East and North-Australian and of tropical Asiatic forest-trees, but no longer represented by living species within Victorian territory. Indeed the fossil species, as far as known, might have been placed in Helicia, or to indicate its supposed affinity it might by the dictates of usage have received the designation Helicites, or in adopting Prof. Schimper's suggestion (Traité de Paléontologie Végétale, i. 54) the name Helicides. But we possess no material for confirming also the generic conformity of the flowers, and thus by adopting incautiously a generic term, expressive of a close affinity, which subsequent discoveries may not bear out, the danger might arise of leading astray or of conveying an incorrect meaning. Hence the choice of an independent name for the genus.

\section{Celyphina MoCoyi.}

In auriferous drift at Haddon in the older pliocene formation, about 150 feet below the surface. John Lynch, Esq.; communicated by R. Brough Smyth, Esq., F.G.S.

Fruit measuring from $\frac{3}{4}$ to $1 \frac{1}{2}$ inch in length, the size evidently to some extent depending on the degree of ripeness; the blunt summit but slightly protracted, the base rounded; pericarp rather more than 2 lines thick in the ordinary form, hut occasionally of double that thickness ; the cavity smooth, presenting on cross-section an oval outline. The seed in its perfect form is unknown, but must have been large and turgid.

The similarity of this fossil to the fruit of Helicia præalta (F. M. Fragm. Phytogr. Austr. iii. 37), from the warmer parts of East Australia seems obvious, as well in size (which is variable likewise in that Helicia) as also in the form and thickness of the pericarp.

As a mark of public homage I dedicate this particular Victorian fossil to Professor F. McCoy, who, by extensive researches, has shed so much light on the flora and fauna of former creations, and who is still daily enriching our stores of protogean knowledge.

Whether the single specimen of a larger fruit from the Gladstone mine of Haddon (illustrated by figs. 5 and 6 ) is also referable as a mere variety of Celyphina 
McCoyi, or whether (as I can hardly anticipate) it forms a distinct species of the same or of an allied genus, must remain for the present undecided. This fruitspecimen is fully 2 inches long, slightly attenuated at the summit and much contracted at the base.

As an abnormal form I referred also temporarily to this species the fossil, of which a drawing has been given at fig. 4 ; the inequality of the thickness of the pericarp seems singular but may be accidental; the cavity in this instance is spherical.

\section{Explanation of Lithogram.}

Plate V.

Celyphina McCoyi-Fig. 1, a fruit of normal form. Fig. 2, the same presenting its lateral aspect. Fig. 3, the same laid open, containing crystalline infiltrations. Fig 4 , dorsal and side view of a smaller variety; the same also laid open. Fig. 5, a varicty with roundish cavity. Fig. 6, a larger fruit, probably conspecific, but much protracted at the base. Fig. 7, transverse section of the latter.

All figures of natural size.

\section{ODONTOCARYON.}

Fruit indehiscent, thick-woody, unilocular, one-seeded, ovate-globular in outline, somewhat oblique, slightly compressed, terminated into four large somewhat unequal teeth; the latter from a broad base gradually acutely conical, but not very angular, surrounding the deep depression of the vertex of the fruit; two teeth on one siae of the fruit strictly erect; the two others slightly longer and distinctly bent inward. Seed pendent, ovate, turgid, upwards somewhat more attenuated and compressed.

The name is derived from ojows: tooth, and kapvov: nut.

Odontocaryon Macgregorit.

In the auriferous drifts near Nintingbool, at a depth of about 150 feet. J. Lynch, Esq.

The specimens as yet found are nearly $1_{\frac{1}{2}}^{\frac{1}{2}}$ inches long, and slightly exceed 1 inch in diameter; the larger terminal teeth are about $\frac{1}{3}$ inch long; the vertex is perforated, probably through disintegration. The seed fills the cavity, measures nearly $\frac{2}{3}$ of an inch in length; its structure can no longer be ascertained.

This remarkable fossil, derived probably from a large evergreen tree, is dedicated to the Honorable John Macgregor, M.L.A., one of the first Ministerial administrators of the Department for Mines, and one of the most enlightened among the patrons of science in this part of the globe.

The writer has not ventured to refer this fossil to any natural order, being unaware of any existing or extinct genus to which it bears really close resemblance; but he would also frankly admit, that the young institutions of this colony are as yet affording, both in collections and in libraries, only very inadequate aid and material for independent local contributions towards the knowledge of the organic world; and although the writer's whole private means for a long series of years have been sunk in his researches, they have been too slender to provide for all the auxiliary requirements of his studies here, more particularly concerning palæontologic work. 

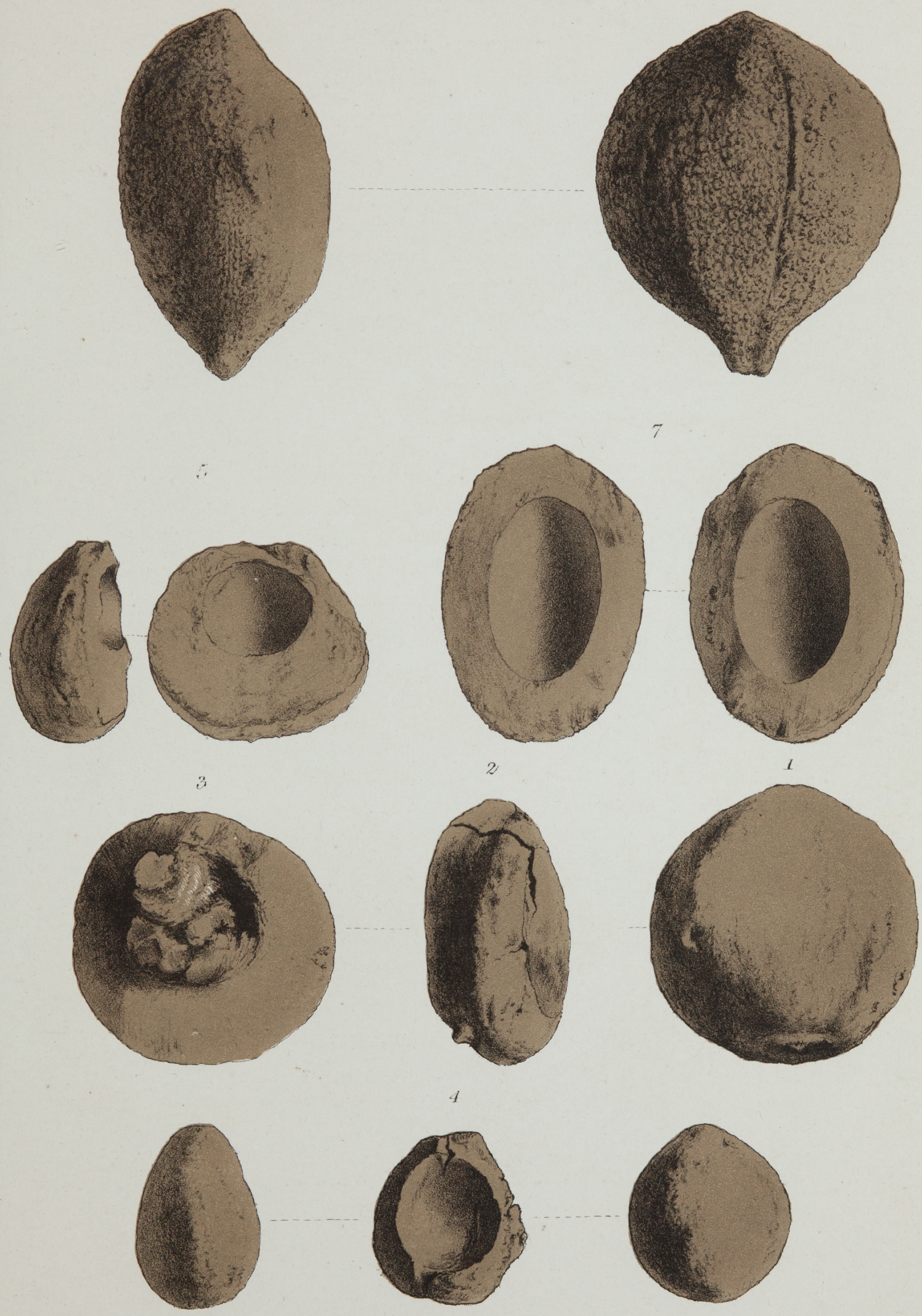



\section{CONCHOTHECA.}

Fruit bony, roundish, considerably compressed, smooth, slightly oblique, bi-valved, one-seeded, short-apiculate at the summit. Cavity on each side very shallow, cordate-orbicular. Seed flat, roundish.

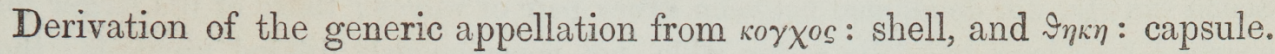

\section{Conchotheca rotundata.}

In the drifts of the older pliocene formation at Nintingbool. J. Lynch, Esq.

The specimen now illustrated measured hardly $\frac{2}{3}$ of an inch. The pericarp is about 1 line thick, except towards the lower extremity, where it is more enlarged.

The general appearance of this fruit reminds of that of several Grevillex, for instance, G. refracta, G. polystachya and G. mimosoides; but in all these the fruit is larger, shows a wider cavity, and is provided with a conspicuous stipes. By this comparison Conchotheca is not even yet admitted to a settled place among Proteaceæ. The Grevillex above referred to are all tropical, and we have in this colony no species living now, which bears resemblance to the fossil compared.

On former occasions already, when assigning systematic positions to Victorian fossils, I adhered to the principal of drawing rather new generic limits for fossil plants known only from extremely fragmentary remnants, than of risking the danger of arraying a bygone species within the same generic precincts with living ones, whenever the generic characters could not be clearly identified. For I do not consider it a real gain of knowledge, when well understood genera of living plants are overburdened with fossil species on the evidence of perhaps only one single organ of a perished plant, moreover when that one organ may not be exclusively characteristic of the genus thus adopted, or not even of the order to which such a genus belongs. Acting on this principle, I have preferred to constitute separate generic limits for the fossil under review on this occasion, instead of placing it directly into the genus Grevillea, as understood in the living vegetation. Nevertheless I have felt justified in comparing it with species of that genus, leaving the final determination until leaves, flowers and seeds shall have become known.

In the collections from Nintingbool fragments occur of an apparently specifically identical fruit, but they exhibit a smaller variety, barely $\frac{1}{2}$ an inch long; the shallow cavity becomes in this almost orbicular. The flat seed measures hardly above 2 lines, is thin and also orbicular. As certainly congeneric, but probably not conspecifie, should not be passed on this oceasion the single valve of a much larger specimen from the same sediment; it measures $1 \frac{1}{3}$ inch in length, verges slightly towards an oval form, while its walls are fully $\frac{1}{4}$ of an inch thick.

\section{RHYTIDOTHECA PLEIOCLINIS.}

Capsule small, woody, generally eight-valved, oval, blunt at the base, impressed at the summit; the edges of the valves meeting to form as many prominent longitudinal ridges as there are valves; the back of the latter slightly hollowed or channelled, not quite even, though also not distinctly tubercular or warty; the sides 
of the valves longitudinally excavated towards the axis for the reception of the seeds; the latter solitary, erect, arising from the base of the cavity, turgid, elongated, wingless, slightly curved.

In the drifts of the lower pliocene formation at Nintingbool. J. Lynch, Esq.

Fruit varying in length from 4 to 7 lines, comprising a larger and smaller form. Seeds smooth, not developed between every pair of valves; those of the larger form nearly $\frac{1}{2}$ inch long and fully a line wide, not conspicuously dilated upwards; those of the smaller form hardly $\frac{1}{4}$ inch long and of about $\frac{1}{2}$ line thickness. In some cases, when the seed is but slightly developed, the shining walls of the cell are obliquely transverse-striated, assuming an appearance as if numerous ovules were arranged along the axis.

This fossil has been placed in the genus Rhytidotheca, as established in the third quarterly report of the Mining Department for 1871, issued by R. Brough Smyth, Esq. On comparison of Major Shepherd's excellent drawings, it will be observed, that the present species has much smaller fruits than Rhytidotheca Lynchii, that the apex of the capsule is not attenuated, and that the numbers of the valves are more than five. As both fossils came from the same geologic formation and locality, and as they show considerable structural similarity, it was deemed advisable to keep them generically together, until we learn more of the two plants, yielding us as yet only the recorded remnants. Should the new fossil finally require generic separation, then its specific name might become that of the genus.

It remains worthy of note, that a two-valved capsule, evidently of ordinal and perhaps even of generic affinity to Rhytidotheca or Pleioclinis, occurs in Mr. Lynch's collection, but only in a single specimen. It is oval, moderately compressed, particularly upwards, nearly 1 inch long; the outside is wrinkled-tubercular, and may have been verrucose before it was subject to detritus. The seeds are wingless, conspicuously turgid, especially downward, solitary in each cell, narrow-ellipsoid, somewhat obverse-cuneate, attached at their middle to the axis, and about $\frac{1}{2}$ an inch long.

All these fossils also on this occasion have been placed obligingly at the disposal of the writer by R. Brough Smyth, Esq., F.G.S.

\section{Explanation of the Lithogram. \\ Plate VI.}

Rhytidotheca pleioclinis.-Fig. 1, vertical view of the capsule. Fig. 2, side view of the capsule. Figs. 3 and 4 , valves of the larger form.

Odontocaryon MacgregoriI.-Fig. 5, side view of the fruit. Fig. 6, vertical view of the fruit. Fig. 7, the fruit opened lengthwise to show the side and position of the seed. Fig. 8, seed, detached.

Conchotheca rotundata.-Fig. 9, side view of the fruit. Fig. 10, fruit, presenting its edge. Fig. 11, fruit opened lengthwise.

All figures of natural size.

\section{PENTEUNE.}

Fruit five-valved to the base, ovate-globose or broadly ovate; dehiscence loculicidal; valves exceedingly thick, woody, very slightly rough on the dorsal part. Cavity towards the middle part of the valves. Free central axis absent. Ceils five in number. Seeds solitary in each cell, towards their summit attached 


$$
\text { Plate VI. }
$$
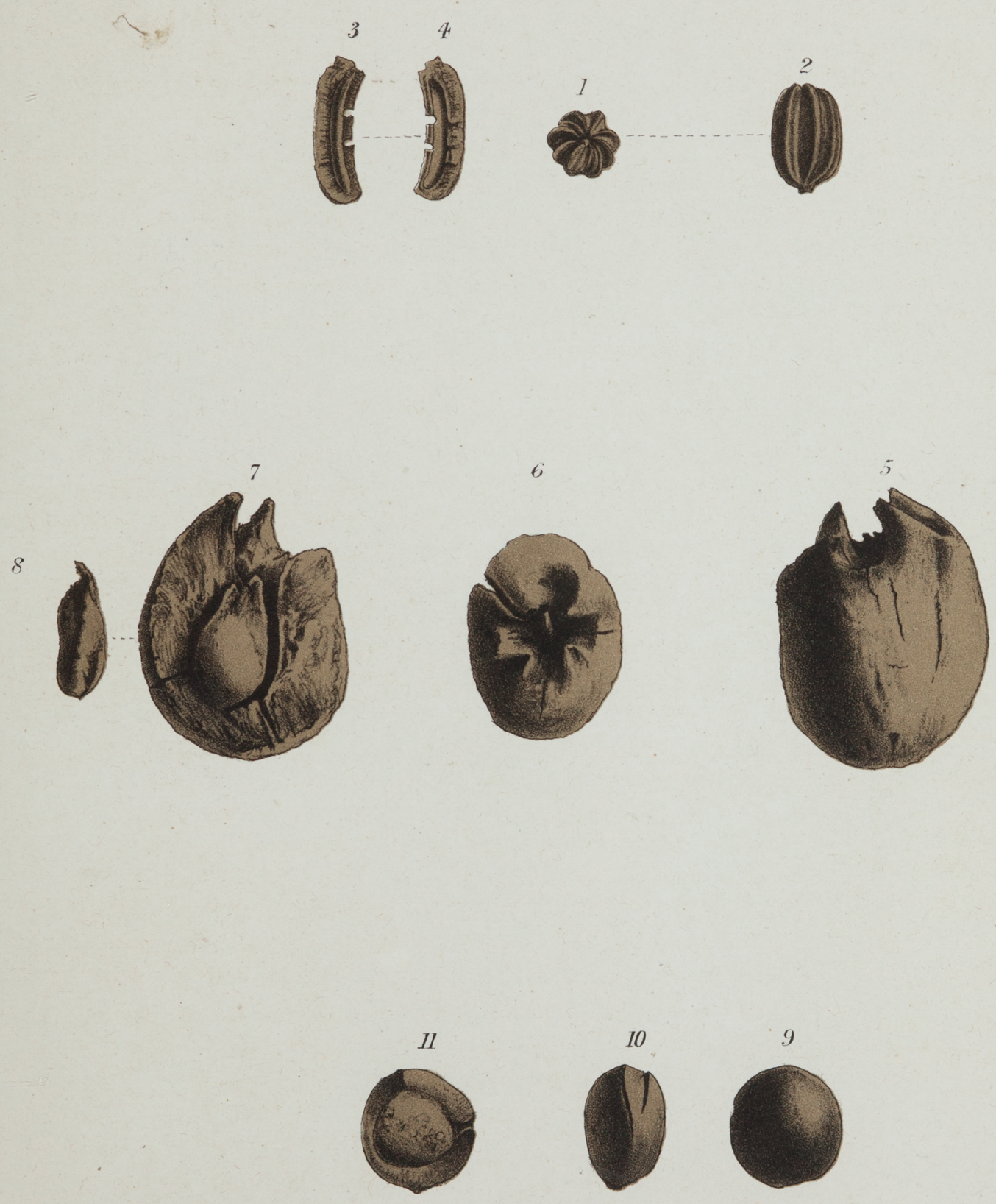




\section{Plate VII}
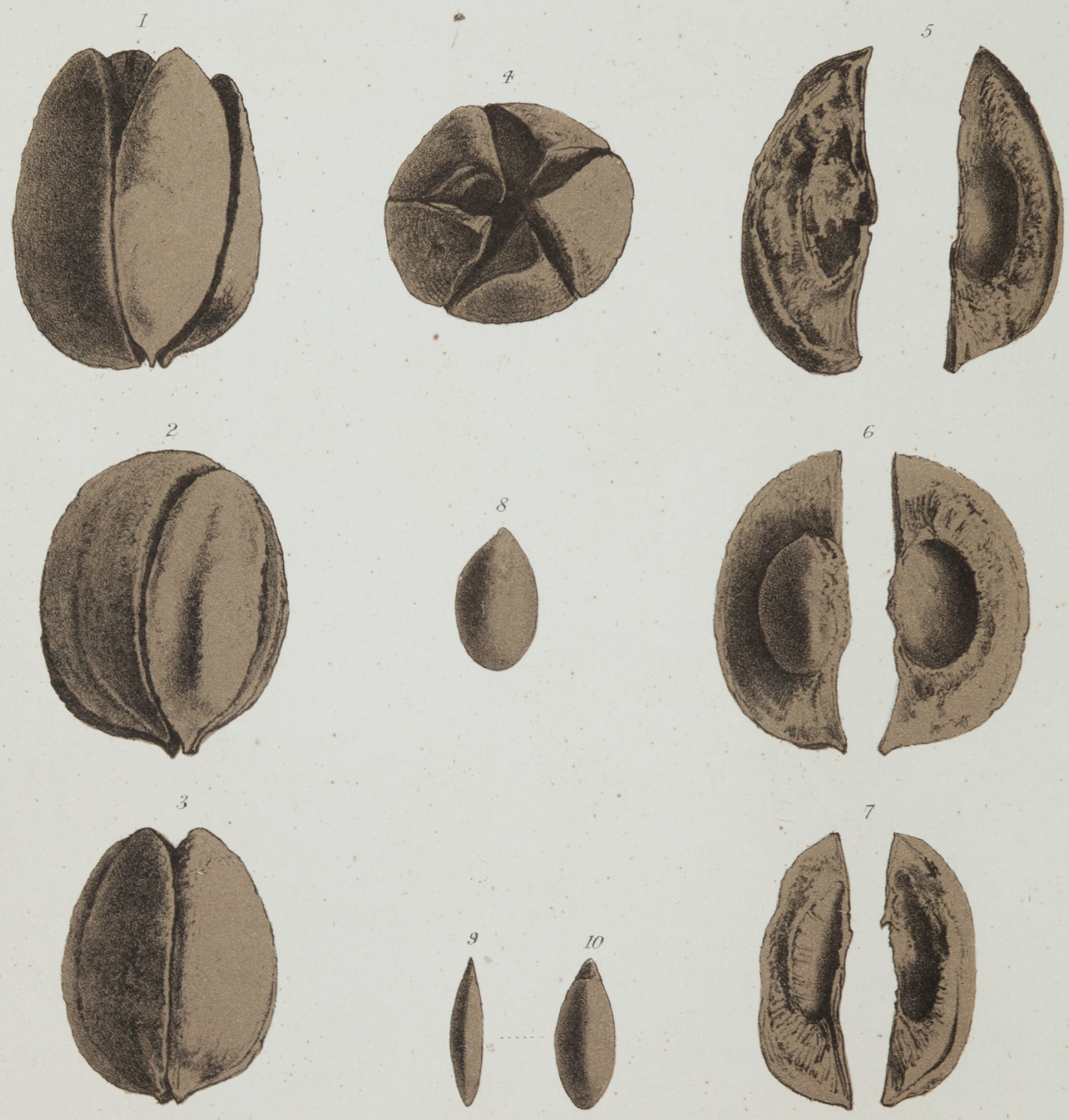
to the inner angles of the valves, turgid, ovate or verging into an ellipsoid form, blunt at the base, more gradually attenuated upwards. Testa smooth.

The generic name-composed of $\pi \varepsilon v \tau \varepsilon$ and $\varepsilon \dot{v} \nu \eta$-is chosen in allusion to the five valves, on which the seeds are imbedded.

\section{Penteune Clarkei.}

In older pliocene drift at Smythe's Creek. J. Lynch, Esq. ; communicated by R. Brough Smyth, Esq., F.G.S., Secretary of the Department for Mines.

The specimens collected are not numerous, and vary in length from $1 \frac{1}{3}$ to nearly 2 inches ; the basal point occasionally protruding. Seeds from nearly $\frac{1}{2}$ to $\frac{2}{3}$ of an inch long, measuring from 3 to 5 lines in their middle diameter; the majority of the seeds remain undeveloped. The radicle must have pointed to the summit.

In the absence of any other identified remnants of this doubtless arboreous plant, no positive systematic position can as yet be found for this genus. It belonged, however, most probably to Sapindacex, although the possibility of its having formed a genus of the Meliaceous order is not excluded.

This conspicuous fossil is dedicated to the Rev. W. B. Clarke, M.A., F.R.G.S., F.G.S., F.Z.S., the nestor among Australian workers in the field of natural science, who amidst the arduous duties of his ecclesiastic calling has carried on with unabating enthusiasm his geologic researches in this continent for nearly half a century.

An externally very similar fossil has been discovered in Tasmania by Morton Alport, Esq., at Gerlston-Bay in tertiary travertin. Some affinity of these fossils to the genus Rhytidotheca is evident from the number of the valves, the dehiscence and the single seed in each cell.

\section{Explanation of Lithogram. \\ Plate VII.}

Penteune Clarker.-Figs. 1, 2, 3, side views of the whole fruit. Fig. 4, fruit, presenting the summit. Figs. 5, 6, 7, inner side view of separated valves. Fig. 8, side view of a seed from a larger form. Figs. 9, 10, back and side view of a seed from a smaller form.

\section{Penteune brachyclinis.}

Fruit comparatively small, roundish, angular ; cavity occupying more than half of the valves.

Found with Penteune Clarkei.

This from a solitary specimen has been placed into the genus Penteune, of which $\mathrm{P}$. Clarkei is to be considered the typical form. It measures only about $1 \mathrm{inch}$, and the valves are of a thickness less considerable than that of the normal species, even if allowance is made for the diminished size. Both P. Clarkei and P. brachyclinis seem, however, to be connected through the form delineated in 7,8 and 9 of the - accompanying Plate viII. ; it is therefore not improbable that they consititute merely varities of one species, and this may have had a range of forms as wide as that produced by Phymatocaryon Mackayi. 


\section{Penteune trachychinis.}

Fruit comparatively large, roundish, externally very rough, almost verrucular ; cavity of the valves sometimes very deep.

Occurs with the two foregoing.

This has been illustrated for completeness sake on this occasion, but merely from the fragments of two specimens, it being desirable to exbibit together the full series of allied species or of varieties, so far as hitherto known. From Phymatocaryon Mackayi this fossil fruit is at once distinguished by the number of the valves.

Figs. 13-17 in Plate VIII. of Major Shepherd's faithful drawing represent a state of the same fossil, but much compressed, probably through distortion in a young state.

\section{Explanation of Lithograms. \\ Plate VIII.}

Penteune bracinyclinis.-Figs. 1, 2, 7, side views of the whole fruit. Figs. 3, 4, fruit dissected longitudinally. Figs. 5, 6, side and back view of a seed. Fig. 8, fruit presenting the summit. Fig. 9, inner side view of separated valves.

Penteune trachychinis.-Figs. 10, 12, fruit dissected longitudinally. Fig. 11, two valves, presenting the summit. Figs. 13, 14, side view of the whole fruit in a compressed state. Fig. 15, the same presenting the summit. Fig. 16, inner side view of a valve with a young seed. Fig. 17, inner side view of an aged valve. All figures drawn according to natural dimensions.

\section{DIEUNE.}

Fruit bi-valved to the base, globular, smooth; valves thick, hard, almost bony; cavity central; septa none. Placenta parietal, thinly filiform, traversing in a single line the middle of each valve longitudinally. Ovules oblong, four to each valve, attached at about equal distances to the placenta. Seeds unknown.

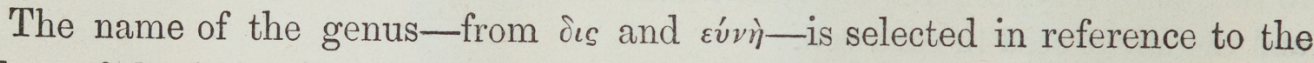
valves of the fruit, only two, on which the seeds are lodged.

The position of the ovules, not sutural, removes this genus from Proteaceæ, although external resemblance is pointing to the woody-valved Grevillex. Its true alliance must perhaps be sought among Capparideæ or Pittosporeæ; but in the absence of the foliage and floral organs the exact systematic position of this probably arboreous plant must remain unsettled for the present. The perfectly valvular fruit separates this genus most readily from Plesiocapparis.

\section{Dieune pluriovulata.}

In the deep drifts of the older pliocene formation at Haddon. John Lynch, Esq.; communicated by R. Brough Smyth, Esq., F.G.S.

As yet only two samples of this fossil have been found; one consists of a single valve showing the number of ovules as stated in the description; the other specimen, of which both valves are extant, exhibits no traces of the ovules. Both these fruits measure somewhat less than one inch; one is quite turgid; the other is slightly compressed; a faint channel communicates from the base of the capsule through the pericarp with the lower extremity of the placenta. Major Shepherd's creditable drawing renders a further description superfluous. 


\section{Plate VIII.}
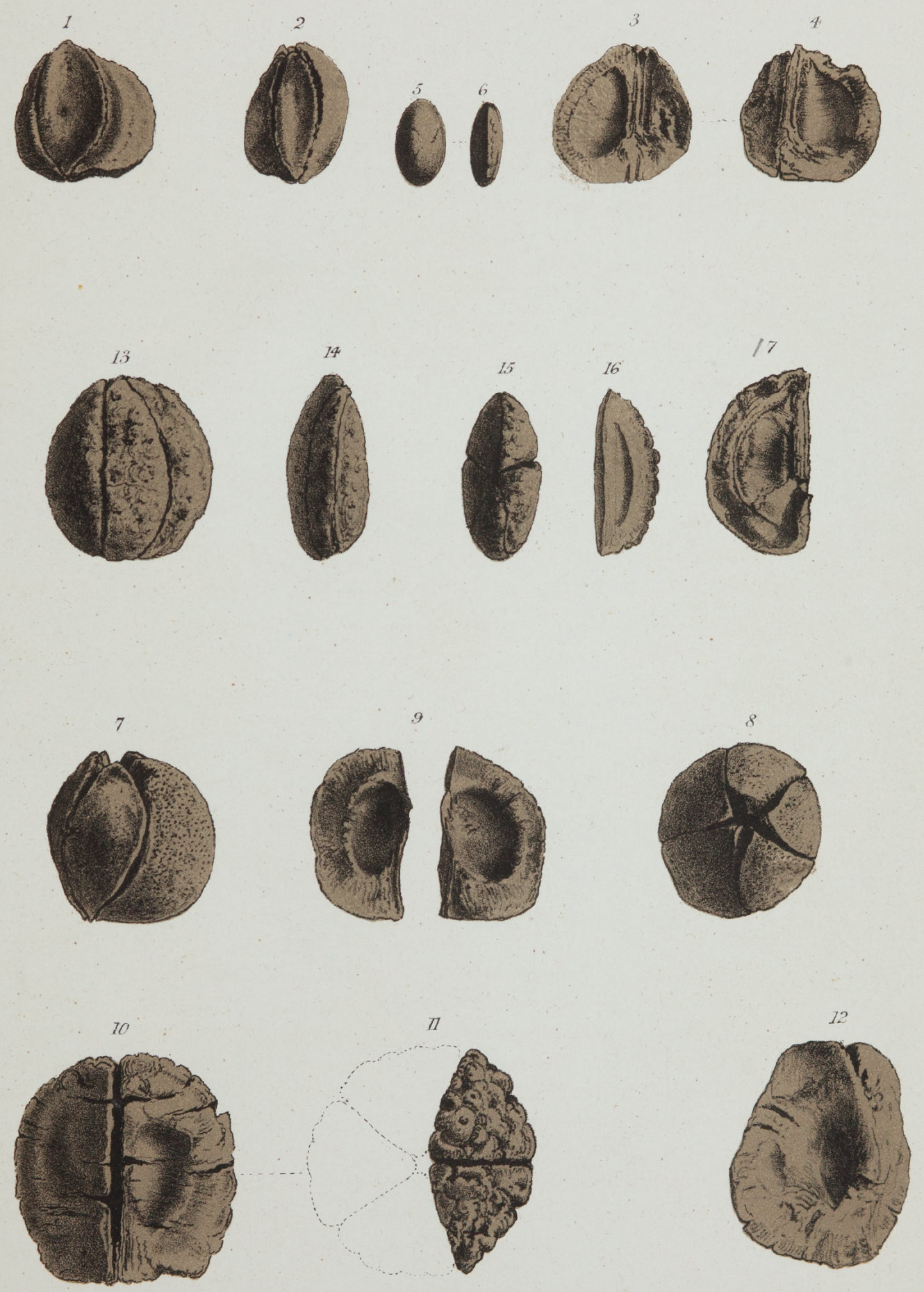




\section{Plate IX.}
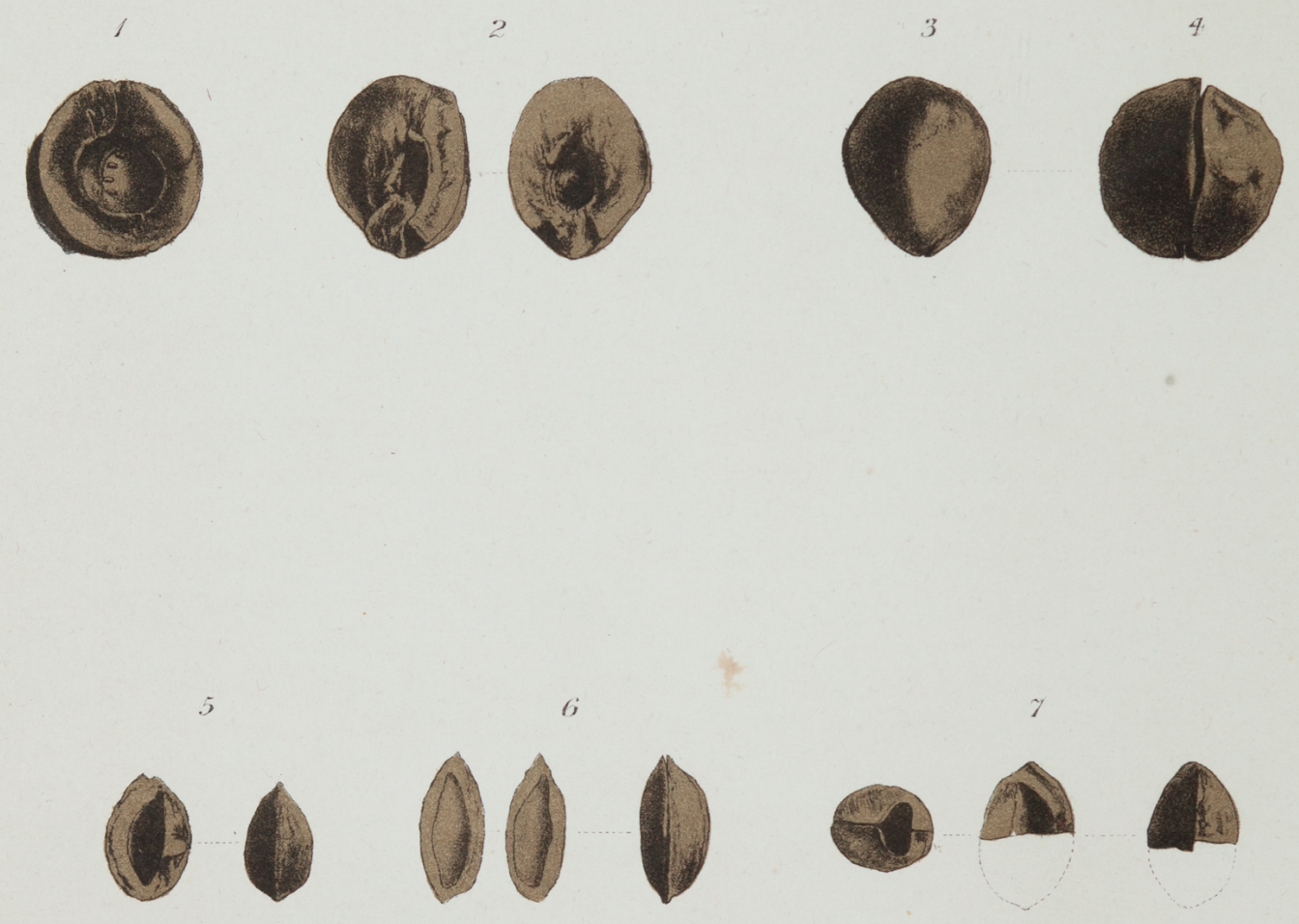

000 


\section{PIATYCOILA.}

Fruit bony, egg-shaped, slightly rough outside, separating into two valves; septa none. Cavity sideways, widely expanded. Seed smooth, solitary, basifixed, arising from the bottom of the cavity, sessile, in its immature state oblong-oval.

The generic name-from $\pi \lambda a \tau v s$, broad, and $k 0 \iota \lambda a$, hollow-alludes to the ample cavity of the capsule, which on transverse section represents a cordate or almost renate outline, and affords thus a characteristic mark by which this genus can be recognised without difficulty in comparison with Conchotheca. It would be unsafe to effect the union of both, especially as we do not yet possess the leaves and flowers for demonstrating generic discrepancies or analogies.

\section{Pratycoila Sollivani.}

In auriferous drifts of the older pliocene strata, near Nintingbool. J. Lynch, Esq.; communicated by R. Brough Smyth, Esq., F.G.S.

This fossil plant received its specific name in commemoration of the Ministerial administration of the Victorian Department of Mines for a lengthened period by the Honorable J. F. Sullivan, M.L.A.

Fruit varying in length from $\frac{1}{3}$ to $\frac{2}{3}$ of an inch. Pericarp comparatively thick, turgid on all sides, but more so in its ventral than its dorsal portion. Mature seeds unknown.

This fossil is particularly deserving further attention of residents in the district where it was disinterred. Both the definition and drawing had to be effected from very fragmentary remnants. A single valve apparently of this species occurs among the fossil fruits recently sent from the River Tanjil.

\section{Explanation of Lithograms. \\ Plate IX.}

Dindne PLURiovilata.-Fig. 1, a single valve in a reversed position, exhibiting the orules attached to the placenta. Fig. 2, two valves of a slightly compressed fruit, presenting the inner side. Fig. 3, dorsal view of a fruit before the separation of its valves. Fig. 4, lateral view of the same.

Platycoila Sullivant.-Figs. 5-9, five fruits of natural size, showing respectively the surface and cavity, also the valves separately; and, in Fig. 9, exhibiting the seed.

All drawings of natural size.

\section{Phymatocaryon angulare.}

Valves three, roundish-ovate in outline, somewhat acute, irregularly rough but not distinctly warty on the outside, forming a prominently triangular capsule.

In the deep drifts at Smythe's Creek in older pliocene strata. J. Lynch, Esq.; communicated by R. Brough Smyth, Esq., F.G.S.

The description and drawing are from a solitary specimen, long laid aside by me with a hope of obtaining additional material for the study of this species. Such not having been gained in the course of several years, it was deemed advisable to 
place this fossil fruit now on permanent record. If the absence of a sarcocarp in this species and its undoubted presence in Phymatocaryon Mackayi can be proved, then the separation of this new one from the genus, in which it is provisionally placed, will become unavoidable; the structure, however, of the valves and the attachment and form of the seeds are congeneric, as may be observed on reference to Major Shepherd's accurate delineation. The length of the fruit is nearly $1 \mathrm{inch}$, that of the seeds 3 to 4 lines. Some external resemblance to the fruit of Penteune brachyclinis is apparent; both, however, are distinguished easily by the number of their valves.

It may be of interest to add on this occasion, that the typical Phymatocaryon Mackayi has more recently been found in at least one locality of New South Wales, according to specimens transmitted by the Rev. W. B. Clarke, also on the River Tanjil and at Eldorado, near Beechworth. In all these places it is accompanied by Spondylostrobus Smythii; while the collections formed by R. A. F. Murray, Esq., on the River Tangil, when that gentleman was engaged there as geological surveyor in departmental work, have demonstrated that likewise Platycoila Sullivani and Celyphina McCoyi occur on that river; we may therefore now assume, that at the early pliocene period these trees were constituting a main portion of the forests over very wide tracts of South-East Australia, impressing features on the landscape singularly different from those of the present era of vegetation under our geographic latitudes and meridians. At the Eldorada mines, near Beechworth, likewise Penteune Clarkei and P. trachyclinis as well as Trematocaryon McLellani have shown themselves, according to collections lately transmitted by R. Arrowsmith, Esq., mining surveyor, Chiltern. The hitherto so rare Odontocaryon Macgregorii has also now been sent in several specimens from the last mentioned place; hence we have learnt, that its fruit assumes occasionally an oval form, that it developes sometimes as many as three collateral seeds, and that the teeth of the pericarp are often all bent inward, thus forming almost valves to the apex of the fruit. The testa is shining, very minutely and closely dotted, whereby the most subtle reticulations arise on the surface of the seeds.

\section{Conchotheca turgida.}

Fruit small, very turgid; valves acute at the edge, outside often distantly wrinkled; cavity deep, roundish ; testa smooth, shining.

At Nintingbool in the older pliocene drift; also at the Tanjil.

The fruit measures from $\frac{1}{2}$ to $\frac{2}{3}$ of an inch in length. Not unfrequently one of the valves traversed for about one third of its length by a keel-like prominence.

Of the several new localities, from which fossil fruits were latterly gained none as yet has yielded us any species additional to those which were brought to light at Nintingbool; nor up to this time has the result of various local searches enabled us to elucidate these bygone forms of vegetable life, in reference to the nature of their foliage and their floral organization. The field of discovery remains therefore yet open, not merely in this respect, but it seems also most probable that the plants, which have been defined carpologically in these pages, were constituting only a small 

0000

- 1

- - 0 
proportion of the sylvan vegetation, which, under a once milder sky, must have been singularly varied and exuberant, and in such a case most traces of these perished forests remain as yet concealed from us.

\section{Explanation of Lithograms.}

\section{Plate X.}

Phymatocaryon angulare.-Fig. 1, side view of the unopened fruit. Fig. 2, unopened fruit, presenting its summit. Fig. 3, fruit opened lengthwise, presenting its three cells, one containing a seed, suspended from the apex of the cavity. Fig. 4, seeds seen separately.

Conchotheca torgida.-Figs. 5, 9, side view of the whole fruit. Figs. 6, 10, whole fruit presenting the apex. Fig. 7, whole fruit presenting the base. Fig. 11, whole fruit presenting the sutural edge. Figs. 8, 12, valves separated, in 12 with a shrivelled seed.

All figures of natural dimensions. 



\section{SPECIAL REPORT ON THE NEW VEGETABLE FOSSILS DISCOVERED NEAR ORANGE, N.S.W.}

By Baron von Mueller, C.M.G., M.D., Ph. D., F.R.S., \&c., \&c.

Melbourne, 29th July 1874.

Sir,

I have the honor to acknowledge the receipt of your communication of yesterday, accompanied by fossil fruits obtained at Orange, in New South Wales, and so thoughtfully transmitted by the editor of the Western Advocate for examination to your Department. These vegetable relics, which represent three species, prove identical with some of the specific forms of the fossils but a few years ago discovered in the pliocene drift of Smythe's Creek, and, with one exception, all only as yet known from that locality.

They belong to:-

1. Spondylostrobus Smythii (F. M. in Lond. Geol. Mag. March 1871, and in R. Brough Smyth's Reports of Mining Surveyors and Registrars 1871. March, pl. I.)

2. Phymatocaryon Mackayi (F. M. in R. Brough Smyth's Reports 1871. June, pl. II.) Both the large and minute variety. Obtained also very recently from the Rev. W. B. Clarke, F.G.S., as gathered in New South Wales.

3. Penteune Clarkei (F. M. in R. Brough Smyth's Report 1873. December, pl. VII.).*

The discovery of these organic remnants in a far distant tract of country in New South Wales, is not without considerable interest, inasmuch as thereby now is shown, that the pristine forests, which have left us these vestiges, were of wide geographic extent. Moreover we may probably connect, in all instances, the occurrence of

* There are also two fragments of a fourth, and perhaps unknown, fossil fruit; but the material does not suffice for exact identification. 
these fossils with adjacent auriferous strata of rich yield, and may thus obtain additional indications and directions for future searches after the richest of our metallic wealth. Though through your own enlightened consideration in the essays referred to, a diagnostic and illustrative account of these three genera, and other concomitant fossils, became promulgated, we yet possess no data to reconstruct imaginarily in their integrity these particular Australian trees of the last of the past epochs.

We yet require to learn, what was the nature of their leaves and floral organs; and these, although so much more perishable than the woody fruits, may still be found preserved on most favorable spots, particularly those of the Spondylostrobus, as the resinous contents of branches and foliage of all coniferæ offer great resistance to decay.

The general enquiry into the constituents of these bygone forests is also far from exhausted ; indeed a well directed and persevering search in any locality, where fossils of these kinds may come to light would, doubtless, not only augment our knowledge of the species already disinterred but also would likely add new generic and specific types to the store of those revealed already by palæontologic science in so many parts of the globe.

I have the honor to be, Sir,

Your obedient,

FERD. VON MUELLER.

To R. Brough Smyth, Esq., F.G.S., Secretary of Mines.

NoтE.-Mr. J. S. Thomas, to whose kindness the Department is indebted for the fossils named in the above report, informs me that the shaft in which they were found is about 100 feet.in depth, 85 of which is volcanic rock. Under the volcanic rock, as in Victoria, is a stratum of mud or clay, with decomposed vegetable matter and trunks of trees; and beneath this, resting on the bed-rock, is the auriferous gravel (wash-dirt) in which the fossil seeds are found.

It is interesting to compare this section with those given by Mr. Lynch, Mr. Arrowsmith, and Mr. Reginald A. F. Murray.

1st Oetober 1874 .

R. B. S. 


\section{ON THE DISCOVERY OF VEGETABLE FOSSILS NEAR NINTINGBOOL.}

By Mr. John Lynch, Mining Surveyor.

Mr Dear Sir,

Smythesdale, 1st February 1870.

I have this day forwarded to you a collection of fossil plants, which I think will please you. They were found in the claim of the Crucible Company, near Nintingbool, at a depth of 70 feet, and about 2 feet from the bed rock. They were imbedded in loose black sandy drift (wash-dirt). It appears that from the "Crucible" northwards through McLachlan's P.R., they are very abundant, and confined, as far as can be yet ascertained, to the very deepest ground, as I have never heard of their being found in any of the adjoining diggings. I have packed them in the sand in which they were found, but it has been passed through the sluice-boxes. A piece of wood found in the same drive accompanies them. The drift where they were found is loose, black, and remarkably free from large boulders, whereas in other parts of the claim the washdirt is cohesive, of various colors, and has embedded in it immensely large quartz boulders. Some of those I send to-day were collected by Mr. Chas. Thorne-from whom I procured the former collection - and the remainder by the officers of the company.

There is one (enclosed in the tin box) which seems to differ from the others. It was found a few years ago in the Pre-emptive claim, Nintingbool, where those in possession of Mrs. Burke were found. I got it from Mr. Montgomery, of Linton.

The manager of the "Reform Company," at Haddon, whose claim is on a continuation of the same deep ground as the "Crucible" and "Pre-emptive," is engaged in making another collection, which, from what I can learn, will prove still more interesting than the present one. It appears that the workmen in opening up a certain drive discovered a tree, or fragment of one, lying in the drift, and 
adjacent to some very interesting specimens of fruit. The manager promised me that he would use every endeavour to recover the tree without injury, but at the same time stated that he never heard of its existence before I had informed him. I got my information from the workmen. Upon my mentioning to the manager and others that you would be pleased to get anything of the kind sought for, they one and all expressed an anxious desire to do what they could to oblige one who has done so much to confer upon Victorian mining something of the dignity of science.

I am, dear Sir,

Yours very faithfully,

R. Brough Smyth, Esq.,

JOHN LYNCH. \&c., \&c., \&c. 


\section{ON THE DISCOVERY OF VEGETABLE FOSSILS AT TANJIL.}

SIR,

Sunnyside, Sale, 20th September 1874.

Herewith I have the honor to forward a few specimens of fossil fruits found in a deep lead beneath basalt, worked by the Pioneer Company, Tanjil. On my pointing out their probable scientific importance, the manager, Mr. Hapff, promised to collect a number more for me when underground work, now suspended, is resumed.

I would beg that the specimens be submitted to Baron von Mueller or Professor McCoy, in order that I may be supplied with a proper description of them to embody in my report.

I have the honor to be, Sir,

Your obedient Servant,

REGINALD A. F. MURRAY,

M. \& G. S.

R. Brough Smyth, Esq.,

Secretary for Mines, \&c., \&c.,

Melbourne. 

("I B I.Z: cos SHAF"l

$\because A \mathbb{D} \bigcirc \mathbb{N}$
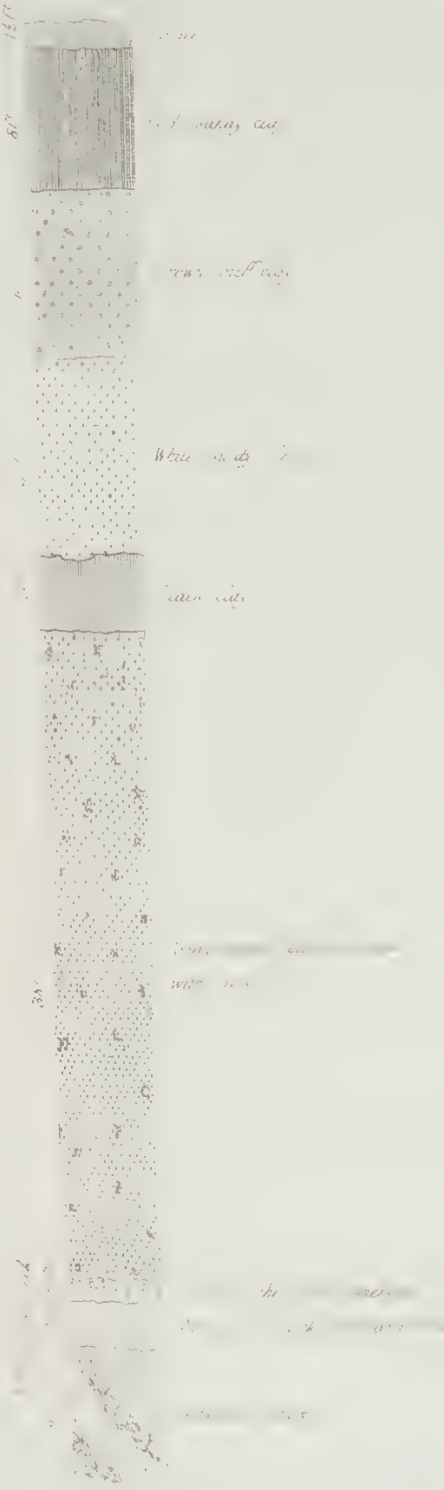

C ROS S

SE C T I O N

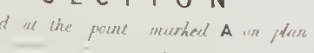

the Eassil Irees found Eossil frut foind

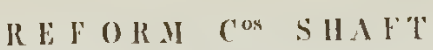

IIII $\therefore$... (D) $\mathbb{N}$

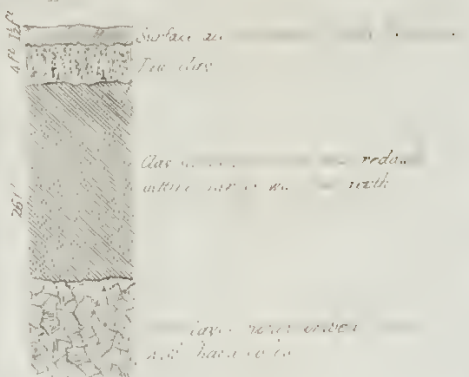

CROSS SECTION

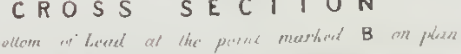

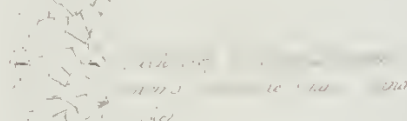

$-\frac{1}{2}$

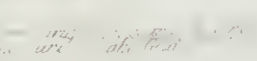

WELL

\section{PORTION OF HADDON COLD FIELD}

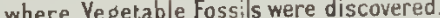
with illustrative sections.

Blese k if ill

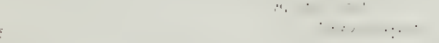

SECTION

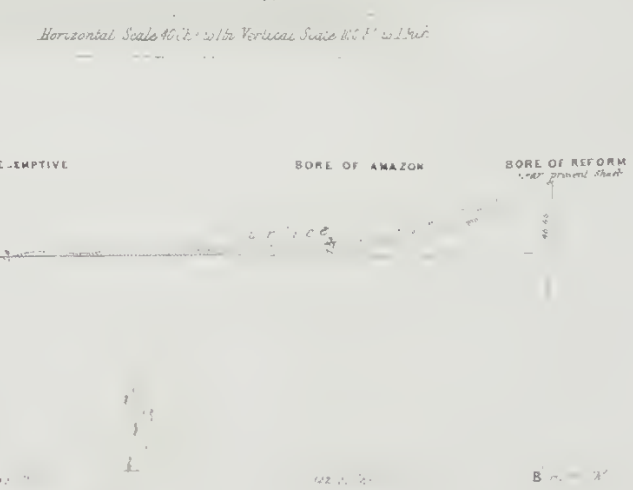

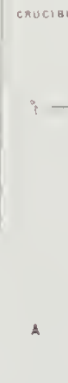



UNITED OVENS G.ET.M.CO S SHAFT

E. D D ( R.MI)

- at A on Plan

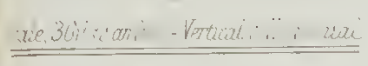

serefterer ritut

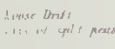

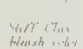

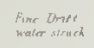

Arithe Drant
nume vele

Fine Bran

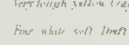

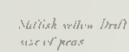

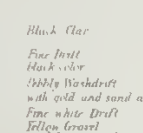

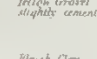

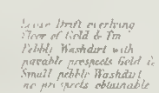

\section{Fuc ivivi wink}

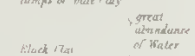

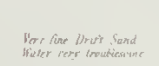

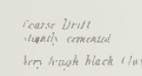

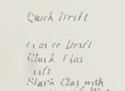

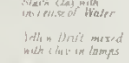

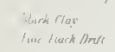

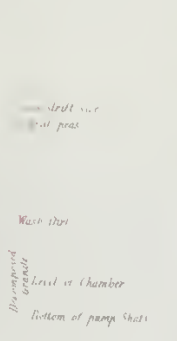

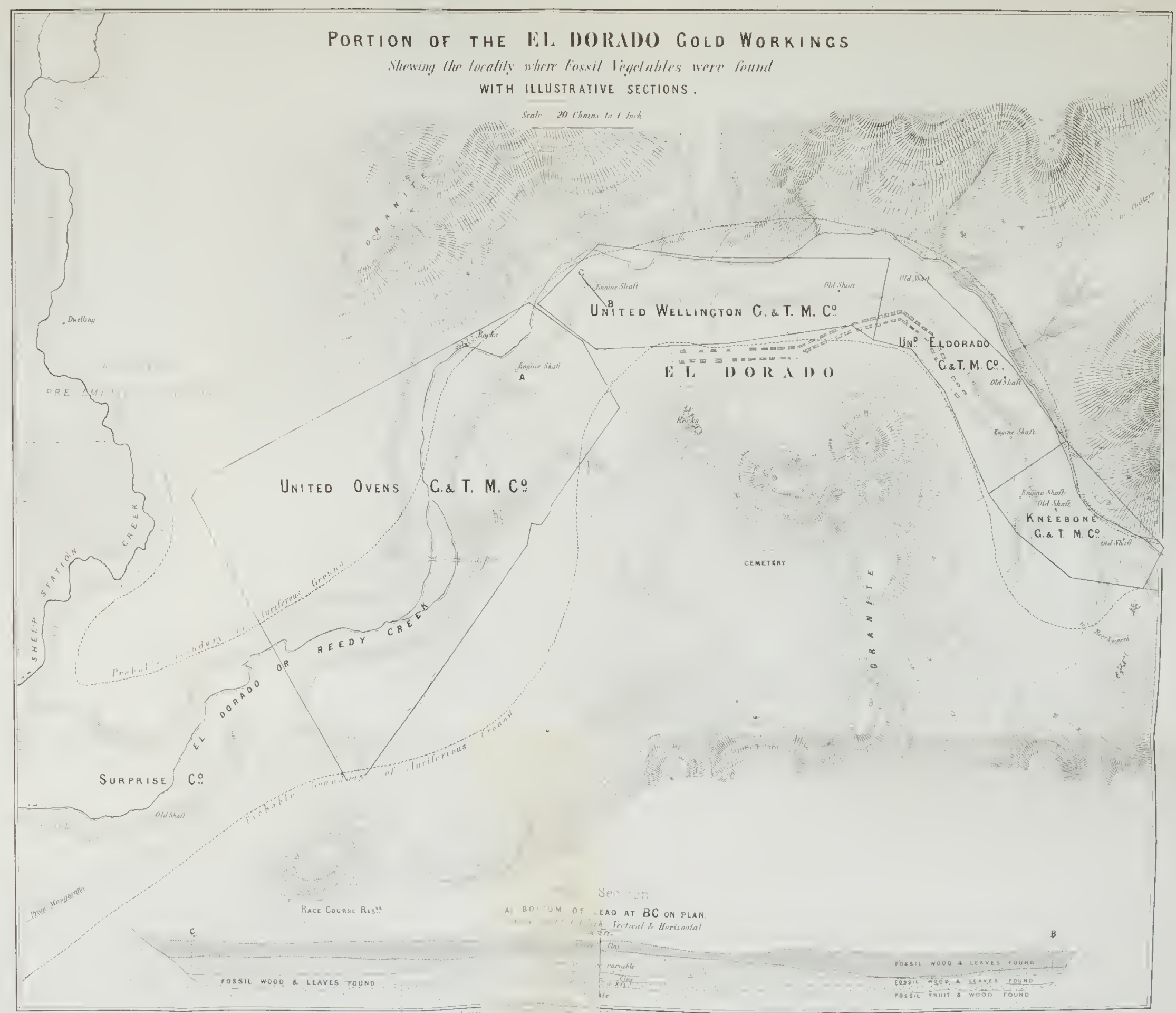







\title{
(beolonital Surrten of Wictoria.
}

\author{
OBSERVATIONS
}

of

\section{NEW VEGETABLE FOSSILS}

OF THE

\section{AURIFEROUS DRIFIS;}

\section{BARON FERDINAND VON MUELLER,}

K.C.M.G., M.D., Ph.D., F.I.S., F.I.N and F.G.S.; Covernment Botanist.

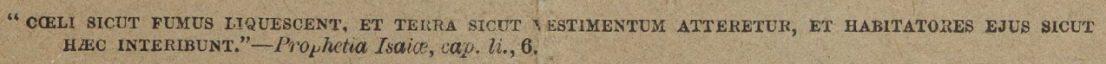

\section{SECOND DEGADI.}

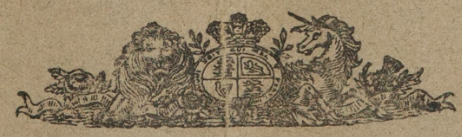

MELBOURNE :

BY AUTHORITY : JOHN FERRES, GOVERNMENT PRINTER.

LONDON :

TRÜBNER AND CO., 57 AND 59 LUDGATE HLL.

MDcoca $\bar{x} \times x \times 11$. 



\title{
Obeolonital Surten of Wittoria.
}

\author{
OBSERVATIONS
}

ON

\section{NEW VEGETABLE FOSSILS}

OF THE

\section{AURIFEROUS DRIFTS;}

\author{
BY \\ BARON FERDINAND VON MUELLER, \\ K.C.M.G., M.D., Ph.D., F.R.S., F.L.S. and F.G.S.; Government Botanist.
}

" COELT SICUT FUMUS LIQUESCENT, ET TERRA SICUT VESTIMENTUM ATTERETUR, ET HABITATORES EJUS SICUT HEC INTERIBUNT."-Prophetia Isaice, cap. li, 6.

SECOND DECADE.

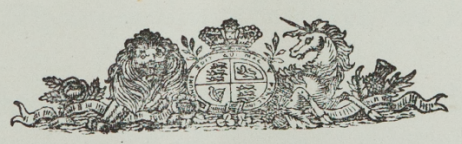

MELBOURNE :

BY AUTHORITY : JOHN FERRES, GOVERNMENT PRINTER.

LONDON :

TRÜBNER AND CO., 57 AND 59 LUDGATE HILL.

MDCCCLXXXIII. 



\title{
OBSERVATIONS
}

ON

\section{NEW VEGETABLE FOSSILS OF THE AURIFEROUS DRIFTS,}

\author{
By BARON FERD. VON MUELLER,
}

K.C.M.G., Ph.D., M.D., F.R.S., F.G.S., Government Botanist for Victoria,

\section{XYLOCARYON.}

F. v. M. in Reports of the Mining Surveyors and Registrars, June 1875.

Fruit large, globular, unilocular, one-seeded, wrinkled and foveolarimpressed. Pericarp of very thick woody consistence, with five to six very prominent obtuse longitudinal ridges protruding into the cavity. Seed large, lengthwise sinuously five- or six-lobed by the intrusions of the pericarp, closely fitted to the cavity. Testa smooth.

Derivation of the systematic name from $\xi v \lambda o v$, wood and кapvov, nut.

\section{XrLOCARYoN LockiI.}

In sedimentary strata at Nintingbool, probably of the lower pliocene state. J. Lyr h, Esq.

The whole material, on which the description and also Major Shepherd's drawing are founded, consists of two specimens of the fruit solely. As may be noted from the lithographic illustration, these fruits measure. fully 2 inches across, and rather more in length. The average thickness of the pericarp is $\frac{1}{2}$ inch; but where it passes into the cavity and penetrates the seed its width attains to $1 \mathrm{inch}$. The seed, though closely pressed into the cavity, seems free, except at one extremity; but as no remnant of the fruit-stalk or its cicatrix remains observable on the specimens hitherto gathered, the position of the seed, whether erect or inverse, 
cannot as yet be determined. The seed in its widest diameter measures nearly $1 \frac{1}{2}$ inch, and its height about the same. Its lobes are considerably or very much broader than the sinuosities and very blunt, but they become evanescent towards the upper and lower extremitios; the pericarpal processes penetrate the seed to nearly one-half its width, or even more. The testa is externally smooth; it seems to have been crustaceous; but by prior infiltration it is internally densely beset in our two specimens with a stratum of bisulphide of iron. As in most fossil seeds, so also in this instance, the embryonic structure and the presence or absence of the albuminous body remain unascertainable.

This grand fruit of probably a large tree of a long bygone age was dedicated to the late R. H. Lock, Esq., who with enlightened views was among the very first to draw attention to the Nintingbool fossils, and to cause them to be secured for palæontographic elucidation.

It might be added, that the genus Xylocaryon would probably best find a place in any systematic arrangement among Olacineæ, of which order as yet no member stands on palæontologic record. Should this conjecture be borne out by future disclosures from more instructive material, then Xylocaryon would take its place in the systematic series near Phlebocalymma (Griffith, in Bentham et Hooker's Genera Plantarum, i. 353) of which Indian genus a new representative has been detected in Queensland (F. v. Mueller, Fragmenta Phytographiæ Australiæ, ix. 151). Affinity would also draw our fossil near to Gonocaryum (Miquel, Prodromus Floræ Sumatranæ, 343), the fruit of which has recently been described by Dr. Scheffer (Annales du Jardin Botanique de Buitenzorg, i. 13), the close relationship between Gonocaryum and Villaresia being thus established.

In the locality of discovery this new fossil was accompanied by many of the fruits, previously obtained from the Nintingbool-layers; thus by Spondylostrobus Smythii (which there, though very rarely, produces a trimerous cone), by Conchotheca rotundata, by a six-valved variety of Penteune brachyclinis, by P. trachyclinis (which latter in its though rare four-valved fruit bears much resemblance to Phymatocaryon Mackayi), then by the last-mentioned fossil, also by Platycoila Sullivani and Rhytidotheca Lynchii (in which latter, according to the position of the seeds for their wing-like expansion on one side no space is left); but according to the present sending a far more copious mass of Celyphina MacCoyi and Plesiocapparis prisca associates with the Xylocaryon; while forms both of Celyphina and Plesiocapparis do occur, which give to each other, as also to the Xylocaryon, a mutual external similarity, although the comparatively brittle shell and the ridgeless cavity of the two former exhibit wide distinctions from the still thicker, tough and not fragile pericarp and the sinuous short subdivisions of the Xylocaryon-fruit. It is indeed not always easy to discriminate between varieties of Celyphina with larger and also turgid fruits in comparison with smaller forms of the fruit of Plesiocapparis. In the former, however, the cavity is always of much less width, the pericarp of greater thickness with a more or less manifest tendency to compression, which could not have arisen from mechanic or accidental pressure alone. The seeds of Celyphina are still unknown; but the Plesiocapparis-fruit has now been found to contain a pulpy mass; whether this pulp was analogous to 



\section{Plate XI}
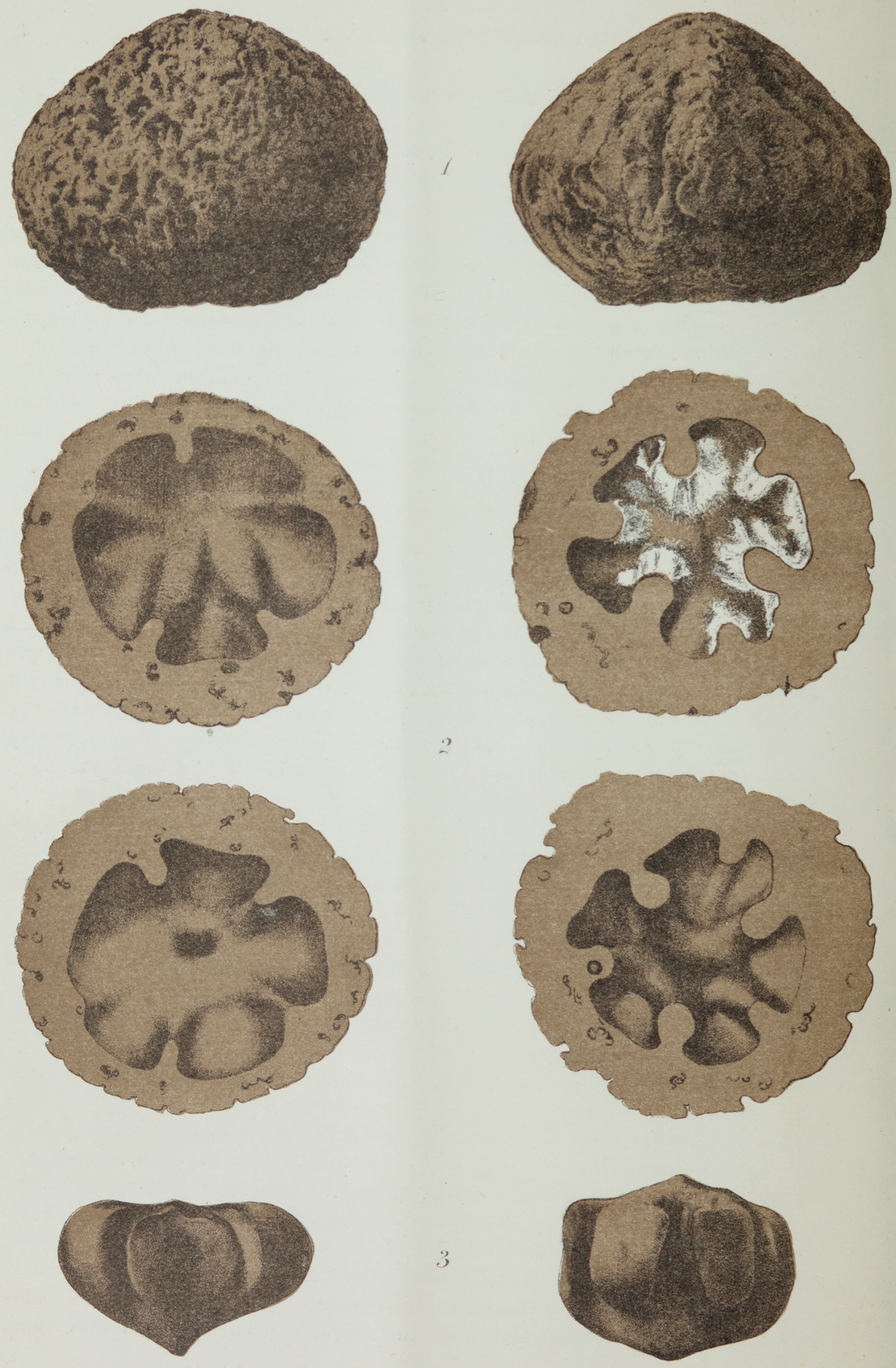
that of the Capers or is merely the result of decomposition of one or more large and perhaps soft seeds, which may have been the only ones coming normally to maturity, remains to be further investigated, and therewith also the validity of the temporary position of Plesiocapparis among Capparideæ. For this purpose specimens from a locality, where they were subjected to no protracted submersion in watery layers of soil, would likely give the safest results. Some of the fruits of Spondylostrobus, brought to light on the present occasion, are of enormous size; when the surface of these is smoothened by detritus, then it is only through dissection and the microscopic examination of the woody tissue, that the Spondylostrobus cone can be readily distinguished from small and equally water-worn forms of Plesiocapparis and even Celyphina. Attention to this is purposely directed here, because the miners, who may be anxious to add thus far to our palæontologic collections, may possibly deem three or more perfectly distinct fossils, which by mollification or external abrasion have become disguised, as absolutely identical.

By the aid of this new disinterment of fossil fruits the remarkable fact seems established, which to some extent was elicited already by former sendings, that the range of variability in reference to the size of these fruits, but not in regard to their structure, was much greater than is observed in cognate now living plants; and a clime would seem to be thereby indicated at the earliest pliocene age, or possibly at the last miocene times, singularly genial for admitting of an unusually exuberant development of the trees, at least so far as their fruits are concerned, during that now comparatively remote epoch.

\section{Explayation of Lithogram. Plate XI.}

Fig. 1, side-views of the whole fruit. Fig. 2, transverse section of the same. Fig. 3, seeds. All natural size.

\section{RHYTIDOCARYON.}

F. v. M. in Annual Report of the Department of Mines of New South Wales, 1875, p. 124, pl. I.

Fruit spherical or slightly ovate, not distinctly dehiscent, one-seeded, with an oblique basal or slightly lateral attachment, woody or bony, externally wrinkled and somewhat tuberculate: Septum large, placentalike, erect or slightly ascending from the bottom of the cavity, consisting of two portions, both smooth, turgid, oblique ovate or sometimes broadly clavate or roundish, always more or less contracted at the base, mutually connate at the middle, rounded at the edges, broadly adnate to the lateral parts of the cavity, free from its summit. Seed cylindrical, bent around the placental or septal protrusion, oblique orbicular- or ovate-hippocrepical in outline, with a marginal furrow. Testa thin, brittle, smooth.

\section{RHYTIDOCARYON WILKINSONII.}

Beneree, under basalt, at a depth of 110 feet; Mr. Edward Farr; communicated by Mr. C. S. Wilkinson. Found also between Carcoar and Orange, by the Rev. 
W. B. Clarke, M.A., F.R.S. Fruits, constituting probably separate carpels of a tricoccous fructification, from $\frac{2}{3}$ to rather above 1 inch long, externally uneven from somewhat irregular slightly concentric ridges, which are often broken up into short tubercules approaching in roughness somewhat to those of Phymatocaryon Mackayi, probably covered originally by a pulpy pericarp, which in decay would early perish, thus the nut-like covering constituting a putamen or endocarp; a very faint cleavage at the base, but no trace of valvular dehiscence; septal process from less than double to nearly triple the width of the walls of the endocarp, except the base and back free from the cavity. Seeds (in all specimens under examination) perished, but their form recognized from the space left for their reception between the dissepiment and the inner faces of the endocarp; remnants of the testa not showing any indications to intrusions into the albumen. The latter and the embryo unknown.

This new fossil, so far as I can judge from the material transmitted to me, brings before us for the first time with certainty a member of the Menispermeæ among the vegetation of bygone creations, inasmuch as of this order hitherto only the altogether doubtful genus McClintockia (Heer, die Fossile der Polarländer, 114-116; Schimper, Traité de Paléontologie Végétale, iii. 83-84, pl. xcviii.) became palæontologically recorded. Unacquainted as we are with the flowers and the embryonic characters of the fruit, we must regard it unsafe, to place this into any of the numerous genera of Menispermex, distinguished mainly by their floral organisation and the inner structure of their fruit; but the endocarp and septal protuberance show some resemblance to the South Asiatic genera Hypserpa (Miers, in Annals of Natural History, sec. ser. vii. 40), Limacia and Nephroica (Laureiro Flora Cochinchinensis, 620 et 692) and the East Australian Sarcopetalum (F. v. M., Plants indigenous to the Colony of Victoria, i.27, pl. iii. Suppl.). The putamen however is more rough than that of any of these genera, and indeed conspicuously thicker than that of any living menispermaceous plant known to me, whilst in its great size the fruit of Rhytidocaryon shows only similarity (and in this respect merely) to Hæmatocarpus (Miers' Contributions to Botany, iii. 324, t. 134). The leaves are unknown. It is probable that the plant, yielding these fruits, formed like most of the menispermaceous order a climbing shrub.

Explanation of Lithogram.

Plate XII.

Rhytidocaryon Wilkinsonir (Figs. 1, 2, 3).-Fig. 1 $a$, anterior view of fruit. Fig. 1b, view of summit of fruit. Fig. $1 c$, dorsal view. Figs. $2 a, 2 b$, anterior and posterior views of larger fruit. Fig. $2 c$, side-view. Fig. $2 d$, interior view, exhibiting cavity and condyle. Figs. $3 a, 3 b$, interior of smaller variety of fruit, showing cavity and condyles. Fig. $3 c$, side view. Figs. $3 d$,
$3 e$, anterior and posterior views.

Figures drawn according to natural dimensions.

\section{WILKINSONIA.}

F. v. M. in Reports of the Mining Surveyors and Registrars, September 1877.

Fruit completely bivalved, one-celled, almost orbicular, more or less truncate, strongly compressed, nearly flat, irregularly traversed by several longitudinal prominent somewhat anastomosing ridges. Seed seemingly 

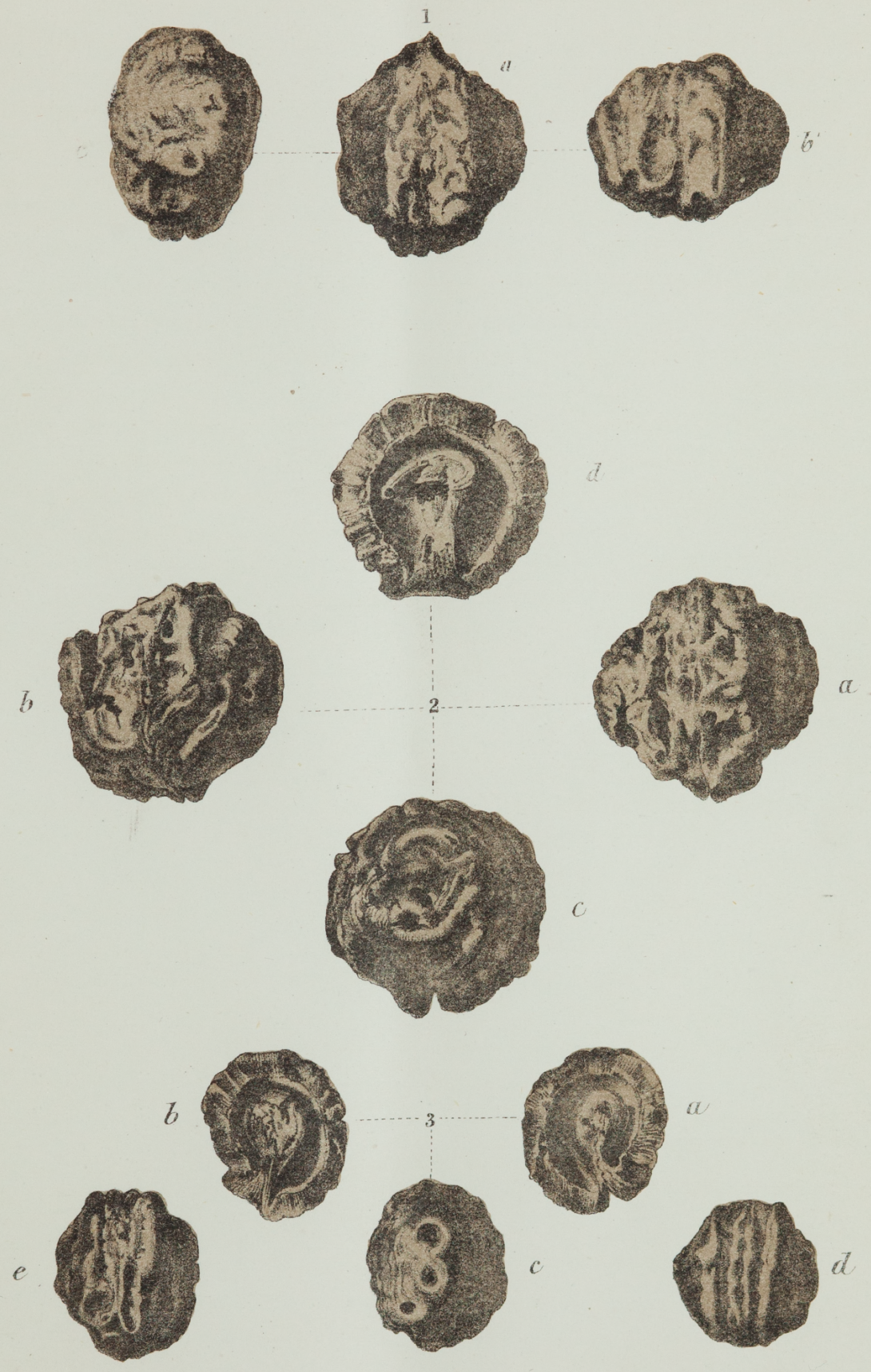




\section{Plate XIII}

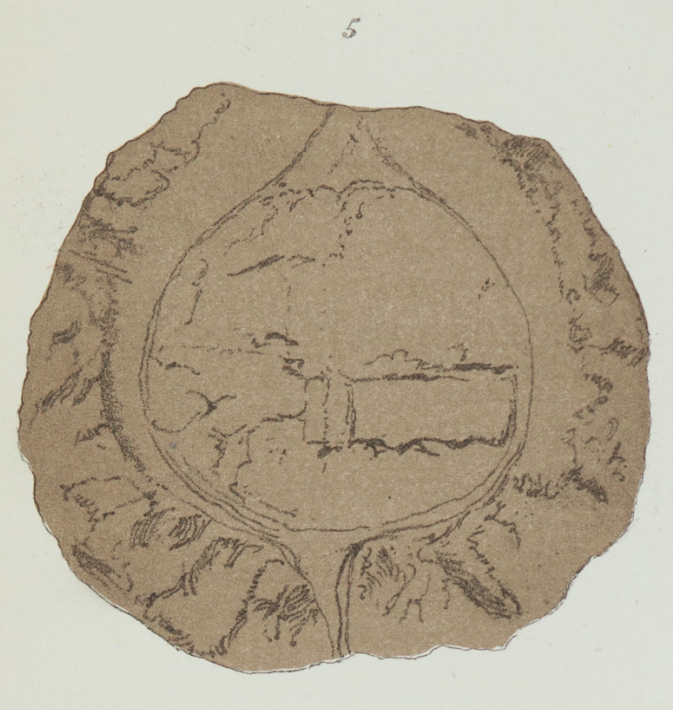

3
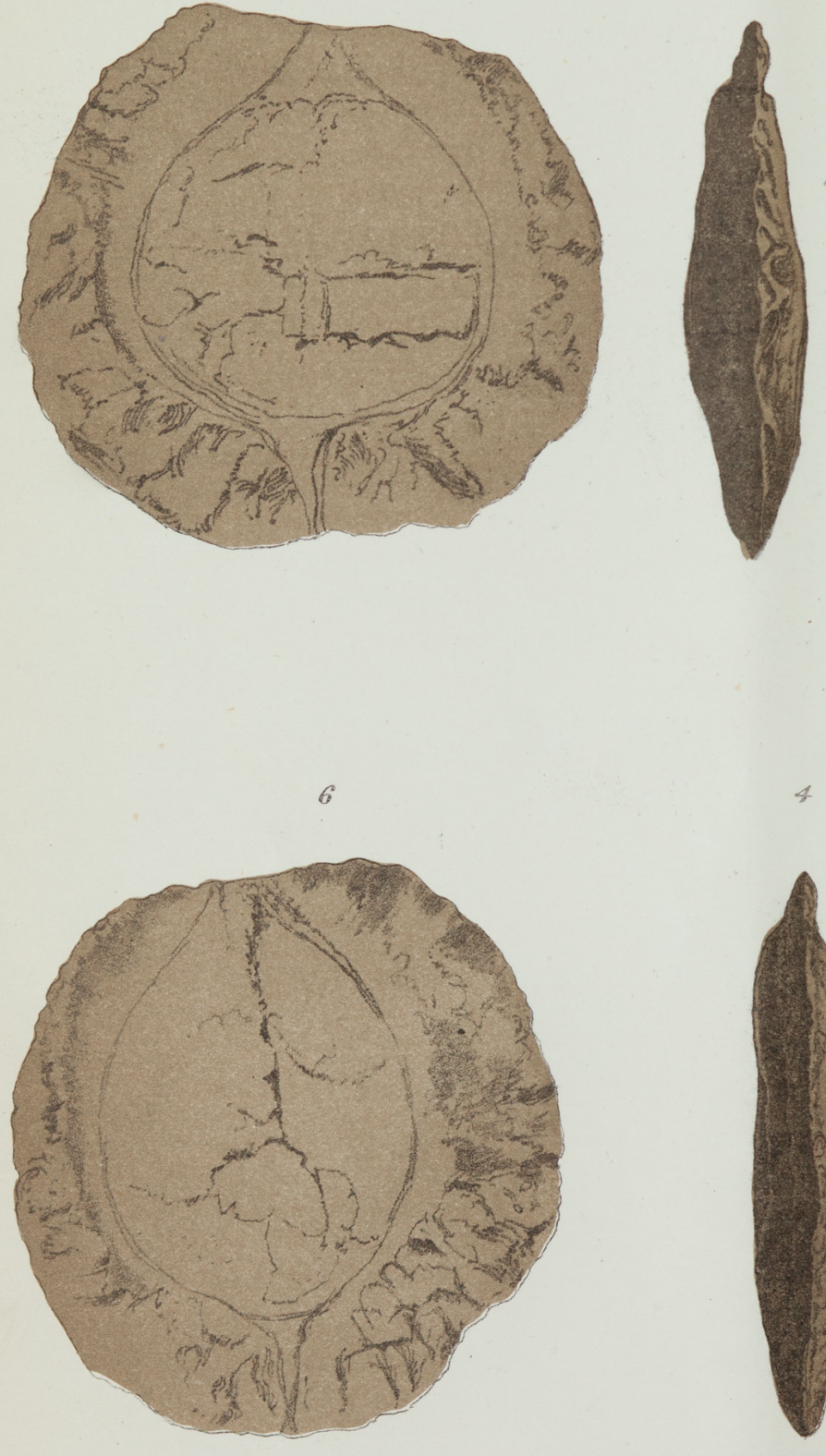
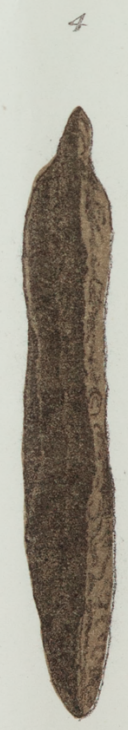

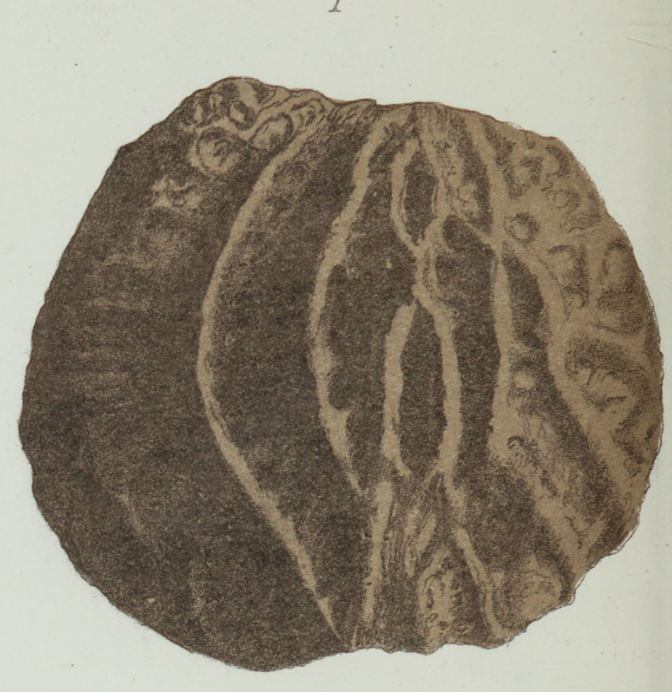

l.

2

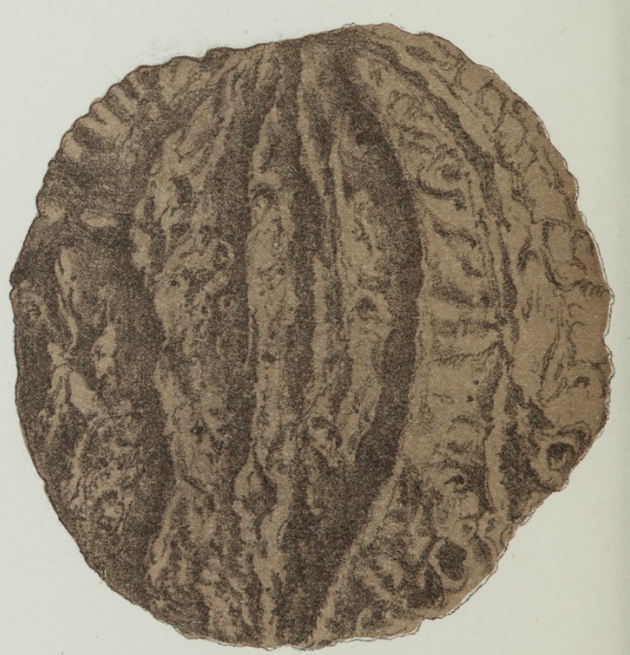


only one, flat, roundish, occupying fully half the space of the valves; its embryonic structure not yet ascertained.

\section{WILKINSONIA BILAMINATA.}

At a depth of about 110-130 feet under basalt at Beneree, C. S. Wilkinson, Esq. and E. Farr, Esq.; in the black lead of Gulgong, 140-175 feet deep beneath a layer (15 feet thick) of basalt, Charles E. Barnard, M.D., F.L.S.

The first specimens of this remarkable fossil were obtained through the circumspect exertions of the Government Geologist of New South Wales, C. S. Wilkinson, Esq., F.G.S., through whose departmental action also many other palæontologic relies of the sister-colony became known. Some of the first discovered specimens of this apparently rare fossil were hardly half the size of those, kindly transmitted by Dr. Barnard, the dimensions of which may be estimated from Major Shepherd's excellent lithograms. The form verges rarely into oval; one of the valves is occasionally more convex than the other. The ramified main-ridges number usually six, they are sometimes slightly flexuous; the interstices, formed by the reticulations, constitute often deep impressions; the edge of the valves acutely attenuated ; the laminæ closely appressed to each other, the exterior ridges nearer to the next than to the margin, and from these lesser elevations radiating. Seed closely filling the shallow cavity, in large specimens measuring rather above one inch in length and breadth; its substance too much decayed in the samples hitherto examined, to ascertain the mode of attachment. The peduncular or pedicellar cicatrix also not yet observed, to arrive at a knowledge of the relative position of the seed.

The plant, producing this remarkable fruit, may perhaps have belonged to the order of Sapindacex; but with the material at present available it is impossible to fix its exact ordinal position, as no external resemblance indicates any close relationship to existing genera. Some similarity to a small ostreoid shell renders the genus Wilkinsonia readily recognized among other fossils. It has received a record in the documents of the Victorian Mines Department, though not yet found in our colony; because as this plant proves to be coeval to the series, published by us here, it is likely, that also this new addition will be traced yet to localities within our colony. It is thus also probable, that the fossil treasures of that particular tertiary period, the upper pliocene, to which we have added already many significant forms, are as yet by no means exhausted by our searches.

\section{Explanation of Lithogram.}

Plate XIII.

Figs. 1 and 2, side-view of fruit. Figs. 3 and 4, marginal view of the same. Figs. 5 and 6 , inner faces of the fruit, exhibiting also the seed. All natural size.

\section{TRICOILOCARYON.}

F. v. M. in Reports of Mining Surveyors and Registrars, March 1878 。

Fruit hard, globular, pointed at both extremities, three-celled, indehiscent; cavities narrow, parallel to the periphery; seeds solitary in each cell, ovate, acute, compressed, smooth. 


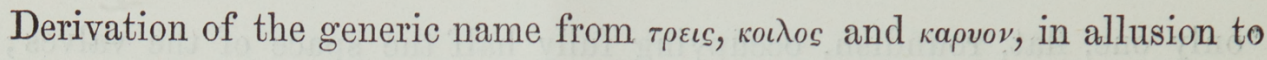
the three-celled nut-like fruit.

The discovery of foliage and particularly flowers of Tricoilocaryon (if it could be effected), though such in all instances are so perishable and so difficult to match, would place the real affinity of this new genus hereafter in a clearer light. Meanwhile it is important to turn organic relics like these at once to palæontologic account, with a view of aiding mining operations in the recognition of the sediments, to which this form of bygone regetation did belong.

The relation of the genera Tricoilocaryon and Pentacoila to Spondylostrobus needs yet to be traced; when fruits of the latter remain covered by water for some time, after they became dislodged from the dry sediments through mining operations, the cones are apt to assume an almost pulpy softness, the organic distinction between valves and axis gets obliterated, and the fruit in that state may readily be taken for a sort of berry with five or a lesser number of seeds; the form of the latter and their position towards the central portion of the axis would indicate, whether such an apparently baccate fruit was merely a mollified state of a Spondylostrobus-cone.

\section{Tricoilocaryon Barnardi.}

In the pliocene drifts, deep under basalt, near Gulgong ; Charl. E. Barnard, M.D.

Fruit about $1 \frac{1}{3}$ inch long, and nearly as broad, externally somewhat rough and wrinkled, inside solid from hardened parenchyma; the three cavities many times narrower than the diameter of the fruit. Seeds about half an inch long, three lines broad, and in thickness hardly exceeding one line.

\section{Explanation of Lithogram.}

Plate XIV.

Tricomlocaryon Barnardi.-Fig. 1, whole fruit. Fig. 2, transverse section of fruit. Fig. 3, seeds, one presenting its side, the other one its edge. Fig. 4, cellular tissue from the inner portion of the fruit. Figs. 1-3, natural size ; fig. 4, diametrically 250 times magnified.

\section{EISOTHECARYON.}

F. v. M. in Annual Report of the Department of Mines of New South Wales 1878, p. 169, pl. III., fig. 2.

Fruit bony, globular or verging into an oval form, slightly depressed or compressed, faintly wrinkled outside, indehiscent or in age slightly bivalvular towards the summit; septum intruding longitudinally and from one side only into the cavity, reaching the middle of the fruit, very much compressed towards the wall, but turgid towards the centre of the cavity ; seed unknown.

I prefer placing this new fossil into a genus, established for it, rather than regarding it merely as a species of the genus Villaresia of the living 


\section{Plate XIV}

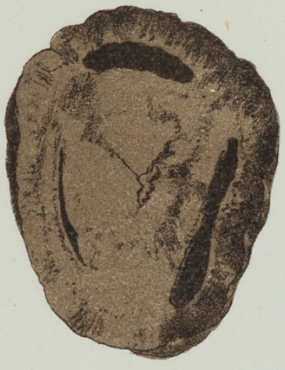

2
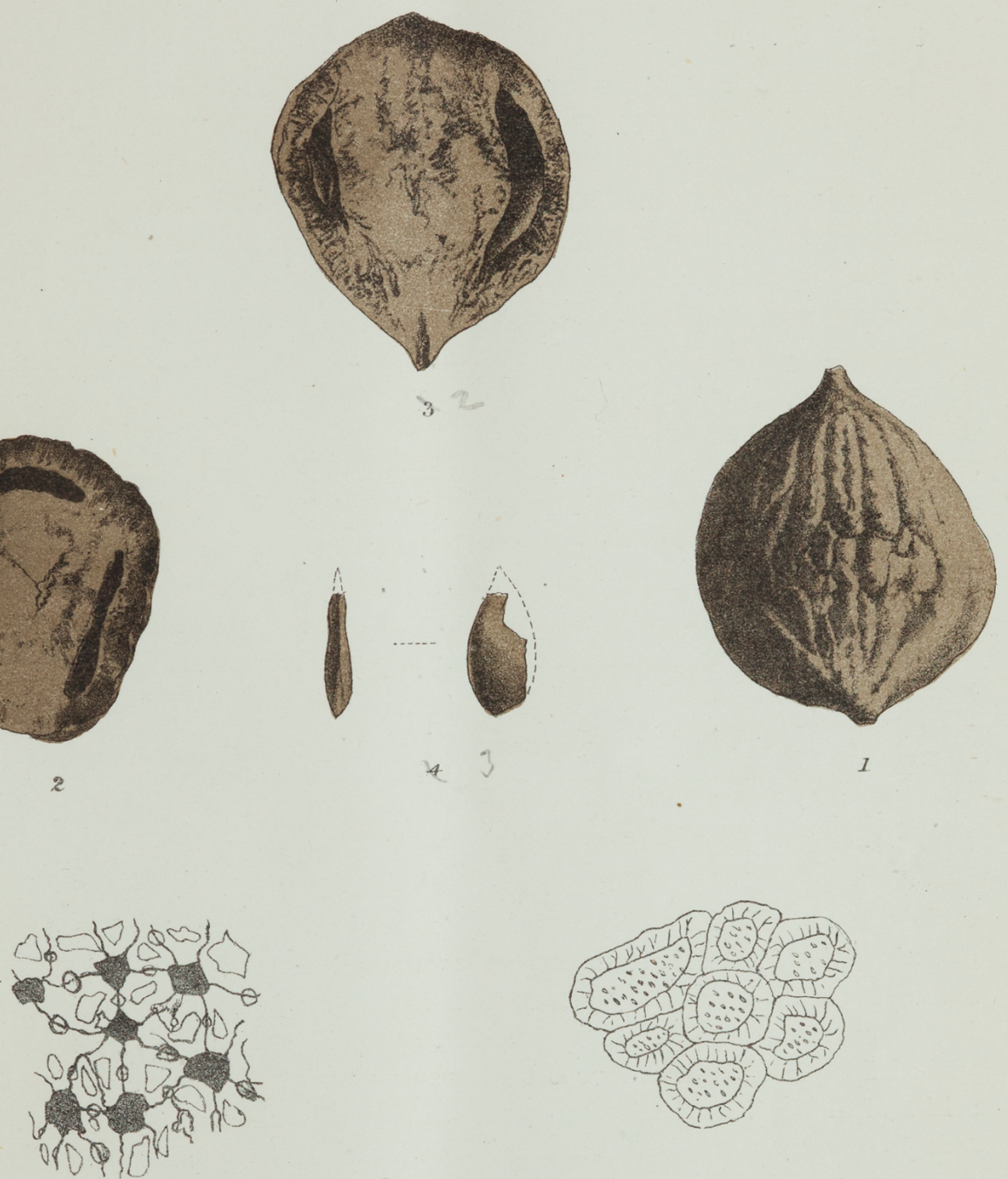

54

54

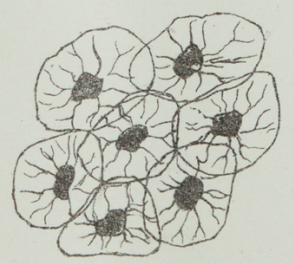

34 




\section{Plate XV}
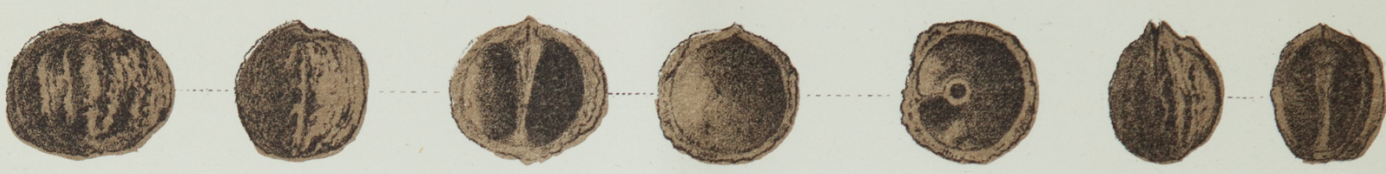

I

2

3

5
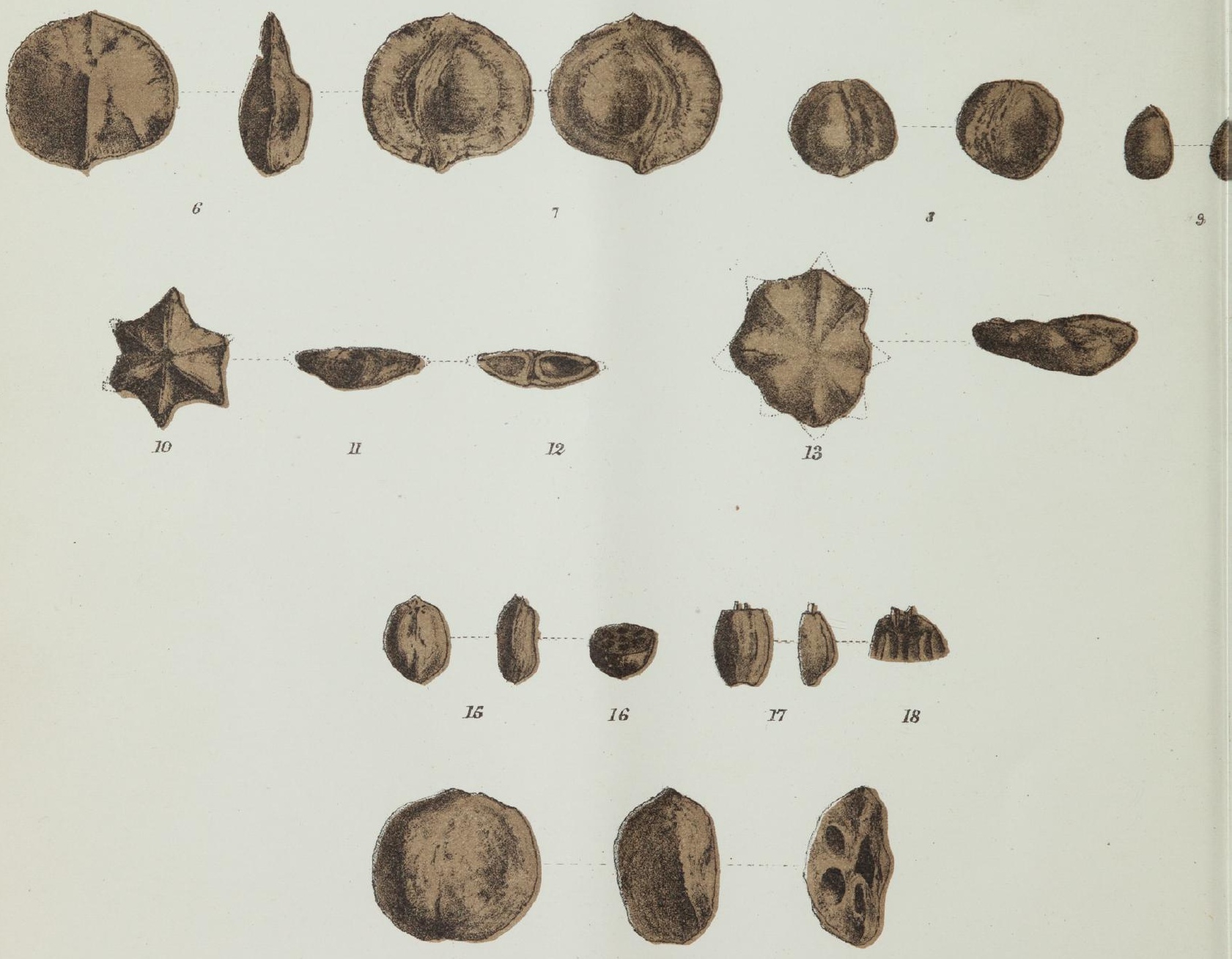

19

20

R Shepherd Del et Iith. 
creation, although the occurrence of two Villaresias in Eastern Australia at the present day may strengthen the assumption of its having been represented likewise during the Pliocene period. If however the view (held by many) should be adopted also in this instance, that the congruency of merely one organ of a fossil plant with that of a living one ought to suffice for establishing generic identity, then accordingly this new fossil should find its systematic location in Villaresia.

\section{Eisothecaryon semiseptatum.}

Fruit measuring from nearly one-half inch to three-quarters of an inch, oftener blunt than pointed; the turgid portion of the dissepiment somewhat hollow along its centre; seed unknown, but in all likelihood curved around the septum. A record of this and the four following fossils, together with some others, appeared already in the Report of the New South Wales Department of Mines for 1876, p. 178-180, from specimens found in the Upper Pliocene layers at Gulgong by C. S. Wilkinson, Esq., Government Geologist of New South Wales. The descriptions, then given by me, were however not accompanied by any figures, which are so essential to aid in the recognition of the particular species of plants now only fossil, in which, as a rule, the structure of the embryo and many other important details can no longer be traced for descriptive diagnosis. The illustrations here offered emanated from the tried skill of Major Shepherd, and will thus greatly facilitate the recognition of any of the specific forms now under review. It was deemed desirable, to give to these new fossils a place also in the series of Victorian species, although as yet they have not been discovered actually within the boundaries of our colony; but inasmuch as at Gulgong all these new species are associated with many others, which do occur in the Upper Pliocene formation of Victoria also, it may be safely inferred, that they belonged all to a complex of silvan vegetation in past ages of wide distribution through the territory now occupied by both colonies.

\section{Explanation of Lithogram.}

Plate XV.

Fig. 1, front- and side-view of the fruit. Fig. 2, longitudinal section of the same. Fig. 3, transverse section of the same. Fig. 4, a fruit showing imperfect dehiscence. Fig. 5, longitudinal section of the same. All natural size.

\section{Phymatocaryon Bivalve.}

F. v. M. in Annual Report of the Department of Mines of New South Wales, 1878, p. 170, pl. III., fig. 2.

Fruit roundish, much compressed, bivalved, two-celled, blunt or slightly protracted at the extremities, almost smooth or but slightly tubercular outside, the valves diverging finally from near their base, one of the cells only seed-bearing or more rarely a seed in each cell developed. Seed exceeding half the length of the valve, oblique-oval, somewhat pointed.

This species differs from $P$. angulare in having merely two valves, which moreover are more acute at the edge. Unacquainted as we are with the foliage and flowers of the plants, which yielded these fruits, we are justified in treating them at 
present, as if they belonged to one genus. Instances of a similar resemblance are afforded in the living vegetation by many genera, such as Pittosporum and Celastrus, in which different species occur with two or more fruit-valves. Specimens were submitted also by the Rev. Jul. Tenison-Woods, F.G.S., in some of which the valves showed a verrucular-roughness; from Nintingbool a variety of quite an oval form was obtained; among the samples from thence occurred also what seems a curious deformity, in which one of the valves, possibly through pressure, became protracted into a wedge-shaped turbinate form.

Explanation of Lithogram.

Plate XV.

Fig. 6, front- and side-view of a fruit. Fig. 7, longitudinal section of the same. Fig. 8, a smaller fruit, laid open longitudinally. Fig. 9, front-and side-view of a seed. All natural size.

\section{ILLICITES.}

F. v. M. in Annual Report of the Department of Mines of New South Wales, 1878, p. 171, pl. IV., figs. $3,4$.

Fruit starlike expanded, consisting of 6-8 carpels; these radiating in one series, connate towards their base, free towards the summit and gradually pointed, almost flat on the lower side, very convex on the upper side, there longitudinally dehiscent, outside wrinkled and streaked as well as slightly granular-rough; vertex of the axis excavated. Seeds unknown.

So far as the very scanty material for examination extends, it might induce us to place this organic relic near the genus Illicium of the living creation, but as nowhere else any species of that genus has hitherto been found among fossils, it was regarded as safer, to frame a separate generic name of similar wording, in accordance with palæontographic usage, for the fossil allied plant. Flowers and foliage, as well as perfect seeds, would also be needed, to establish for this fossil an undisputed position in or near the living genus. As an addition to the Magnoliaceæ of past geologic periods this plant is of particular interest, fossil remnants only of the genera Magnolia and Liriodendron being hitherto on record from this order, and these again mainly of the cretaceous epoch, if indeed their generic recognition was always free of doubt, their description resting often on leaves merely. So also very recently Professor Lesquereux defines anew some supposed Magnolias from leaf-fragments alone in Dr. Hayden's superb series of volumes on the United States geologic survey (Vol. VII., 247-250, t. $\mathrm{XLIV}$. and XLV.). But however valuable these records of fossil foliage may be for aid in defining the age of geologic sediments, yet in most instances the evidence hitherto brought forward does not prove conclusively the generic or even ordinal recognition of such relics. By the aid of the microscope we may yet hope to be able to obtain characteristics of diagnostic 
value from the anatomy of leaves sufficiently positive to recognize ordinal and even perhaps generic groups. But unfortunately very often in fossil leaves the delicate cell-walls and the tender membranes of their vascular structure are too much destroyed for obtaining thus far objects for the compound microscope, otherwise we should have a powerful auxiliary for settling the affinity of many obscure remains of plants. How far this can be done even with living plants remains yet to be extensively studied; but I was enabled for instance, to demonstrate the occurrence of Epacrideæ in New Guinea from the microscopic comparison of the leaf-epidermis of a species, brought from thence without flowers and fruits, with the very peculiar cuticle of many Epacrideæ easily recognized microscopically.

\section{ILLICITES ASTROCARPA.}

Diameter of fruit one-half to one inch, height very much less; in one specimen, smaller than those figured but much deformed, the acute radiating points are well preserved.

\section{Explanation of Lithogram. Plate XV.}

Figs. 10 and 13, fruit seen from above, the points partly worn away. Figs. 11 and 14, lateral view of fruit. Fig. 12, longitudinal section of the same. All natural size.

\section{PLEIACRON.}

F. v. M. in Reports of the Mining Surveyors and Registrars, September 1878.

Fruit small, bony, ovate, smooth, truncate at the summit, terminated by four or six tooth-like short protrusions, 4-6-celled, indehiscent. Seeds solitary in each cell, clavate-ellipsoid, the narrow end upwards.

\section{Pleiacron elachocarpum.}

Fruit only about half-an-inch long or less; the impression of the summit shallow, the teeth almost blunt; a short perforation at the base; cells stretching along the whole length of the fruit. Mode of attachment of the seed not yet ascertained. In the original description a form with four cells was regarded as typical, possibly that with six cells and six teeth may prove specifically distinct. The latter was found to be provided with a short and very thin stalklet. The species had to be described from a solitary specimen of each form, not well preserved either. Not only of Pleiacron but also of the four other genera now illustrated, additional material has to be searched for, to improve upon this first attempt of assigning to them systematic limits.

\section{Explanation of Lithogram.}

Plate XV.

Fig. 15, front- and side-view of a fruit, natural size. Fig. 16, transverse section of the same, natural size. Fig. 17, front- and side-view of the 4-eelled form, natural size. Fig. 18, summit of the same, magnified. 


\section{PENTACOILA.}

F. v. M. in Reports of the Mining Surveyors and Registrars, September 1878.

Fruit bony, compressed-globular, indehiscent, slightly rough outside, fivecelled. Seed solitary in each cell, oval, compressed. Its nearest affinity, so far as can be judged from fruit alone, seems to be with Tricoilocaryon.

\section{Pentacolla Gulgongensis.}

Fruit nearly or fully an inch in length, perhaps hardened only by fossilification ; cavities rather narrow, their walls smooth.

\section{Explanation of Lithogram. Plate XV.}

Fig. 19, front- and side-view of a fruit. Fig. 20, transverse section of the same. Natural size.

\section{Plesiocapparis megasperma.}

F. v. M. in Reports of the Mining Surveyors and Registrars, December 1878.

Fruit globular, neither compressed nor oblique; pericarp very thin, outside almost smooth ; seed solitary, very large, globular; cotyledons hemispherical ; radicle ovate, very minute, enclosed.

In Pliocene drifts, vastly overflown by basalt, near Gulgong; Chas. Barnard, M.D.

The few specimens seen measure about $1 \frac{1}{2}$ inch and are very faintly wrinkled and rough outside. The thickness of the pericarp varies from $\frac{3}{4}$ to $1 \frac{1}{2}$ line; a slightly prominent and gradually evanescent line passing upwards along less than half of the fruit or extending on both sides nearly to its summit. Seed about 1 inch in diameter; its mode of attachment no longer traceable. Cotyledons easily separating from each other and from the endopleura, homogenous, wrinkled merely by exsiccation; radicle about 1 line long.

When the genus Celyphina (in the absence of seeds with much diffidence) was established, I alluded already to its probable affinity with Helicia ; if the discovery of the seeds should bear out hereafter this view, then Celyphina may as a genus become the receptacle also of our new fossil. Externally a great resemblance to Plesiocapparis leptocelyphis is evident at a glance, and the question arises, whether the seeds, figured in first instance, are only ovules advanced in growth, of which one only comes to maturity and then almost fills the whole cavity.

The fact, that in Plesiocapparis several of the seeds (resembling somewhat those of capers) attain a considerable size and are not early suppressed, as is mostly the case in pluri-ovulate but one-seeded fruits, would speak against the generic union, notwithstanding the singular external resemblance of the fossil now under review. Macadamia, to which it verges so closely, produces only two ovules, of which usually only one matures; its radicle is minute and enclosed just as in our fossil fruit; we should thus almost be justified in establishing for the latter a separate generic name (Helicites). "Veritas potius e praevia separatione quam festina unione." On the other side it cannot be denied, that Melicocca among Sapindaceæ exhibits many carpologic characteristics, which agree with the fossil now temporarily placed in Plesiocapparis, although the latter generic name, as indicating a 
very different alliance, does not apply to this new species or form. The affinity to some rosaceous genera (for instance Pygeum), to some meliaceous, sapotaceous and laurinaceous genera, several of which offer great embryonic resemblance, seems to be more remote.

\section{Spondylostrobus Smythit.}

Through the circumspect exertions of Mr. Rob. Johnston, of Launceston, F.L.S., whose enquiries into the geology of some portions of Tasmania are well appreciated since years, I came into the possession of several vegetable fossils from thence, and thus received recently also the drawing of some cupressoid foliage from a place, where fruits of Spondylostrobus Smythii were obtained. This locality is on a small watercourse flowing into the Tamar opposite Georgetown, since famous through the discovery of gold in drifts as well as in rich quartz-reefs. These new goldfields furnish also some other fossil vegetable species, which are indicative of auriferous country in Victoria, New South Wales and Queensland, though in Tasmania these organic relics remained so singularly long concealed.

As hitherto only one single species of coniferous plants has been noted in the gold-drifts, it was to me at once apparent, that at last the foliage of Spondylostrobus had been discovered. The delineation, made from the original impression (the clayey soil since crumbled into dust), did not show with exactitude the numerical arrangement of the leaves in the whorls. In questioning the finder, whether it might have been quinary, he at once replied, that he remembered it to have been such. With this confirmation of what I anticipated, there can now be no longer any reasonable doubt as to this foliage belonging to the same species, which furnishes the fruit described as that of the genus Spondylostrobus. This foliage by the quinary arrangement of its scale-like leaves bears out the symmetry noticed between the number of leaves in a whorl and the numerical fruit divisions of several cupressinous genera. So in Frenela and its subgenus Actinostrobus we find a ternary disposition of the minute leaves combined with a double and usually unequal whorl of ternary fruit-scales, the bracts of the male flowers and mostly also the anthers being placed likewise ternately, while the embryo is also frequently tricotyledonous. In Octoclinis quaternary leaves are normally connected with eight fruit-scales, the latter in two slightly unequal sets. Callitris shows leaves and bracts opposite in single pairs, while the fruit-valves form a double pair, one pair only seed-bearing, whereas the anthers are mostly grouped in four and the two cotyledons two-cleft. In Libocedrus we find as a rule similar numeric proportions. Under these circumstances, though the evidence is not connectedly direct but only circumstantial, we may be justified in uniting the foliage now illustrated with Spondylostrobus-fruit. The drawing here offered is from a sketch of Mr. Johnston, but Major Shepherd has added in dotted lines on the enlarged figure the lost portions of the quinary leaves.

Attention now being directed to the cypress-like leaves of this isolated fossil conifer, it will doubtless soon be found elsewhere. In all probability also the fossil pine-wood, gathered at the localities, at which Spondylostrobus-fruits were obtained, will prove conspecific. The geologic structure of the country, where in 
Tasmania (at the Union Gold Mining Company's ground) this fossil conifer occurs, is described by Mr. Johnston and Mr. Stockman as follows: Surface-clay, 7 feet; then wash-drift with slight indications of gold, 2 feet; then arenaceous pipe-clay, 30 feet ("false bottom"); followed then by a layer of 2 feet of carbonaceous clay with Spondylostrobus and concomitant fossils ; beneath this Silurian "bed-rock." Spondylostrobus-fruits were discovered by Mr. Johnston also in the Ophir Gold Mining Company's shaft (of the Launceston 'Tertiary basin), there sociated with Platycoila Sullivani, Phymatocaryon Mackayi and Conchotheca rotundata. The latter, it may be here passingly observed, has been traced in the Reform Company's claim, about ten miles from Ballarat, to a depth of 400 feet; and the same fossil or a closely allied species has latterly been noticed between Warwick and Towomba in the Clifton coal-mine by Mr. Simson, according to Mr. C. Staiger, F.L.S., Analytic Chemist to the Government of Queensland. There the succession of strata is as follows: 2 feet of volcanic black soil (the surface of the rich pastoral downs), then about 37 feet of Dolerite, after that about 43 feet of drift, on the bottom of which Conchotheca-fruits occur with fossilised wood and drift-quartz, and beneath this commences the coal, worked by the mine.

In Tasmania the Spondylostrobus is accompanied by the leaves of a tree, which possibly may belong to the order of Lauracer, unless indeed these showy leaves constituted the foliage of one of the local plants, described hitherto systematically from fruits alone. Mr. Johnston thinks, that he has recognized fragments of Spondylostrobus-foliage also in the Travertin near Hobarton as well as in the Windmill Hill beds near Launceston; there this fossil is likewise associated with the remains of an extinct Banksia, in all probability identical with the Victorian fossil congener. A variety of Spondylostrobus Smythii was rendered known under the name cryptaxis in the Report of the Department of Mines of New South Wales for 1878, p. 169, pl. III, fig. 1 ; in this aberrant form the valves are as long as the axillary body or even longer, which latter is completely concealed by them; they are separated by but very narrow interstices or become quite contiguous.

Explanation of Lithogram.

Plate XVI.

Plestocapparis megasperma.-Fig. 1, fruit, presenting its side and base. Fig. 2, longitudinal section of fruit. Fig. 3, cotyledons separated, showing the radicle. Fig. 4, tissue of pericarp. Figs. 1-3, natural size ; fig. 4, magnified 200 times diametrically.

Spondylostrobus Smyтur.-Fig. $5 a$, impression of leafy branchlet, natural size. Fig. $5 b$, summit of a branchlet, greatly enlarged, portions of the foliage restored.

\section{Plesiocapparis leptocelyphis.} F. v. M. in Annual Report of the Department of Mines, New South Wales, 1876, p. 180,
pl. IV., fig. 5 .

Fruit comparatively small, slightly or seldom considerably depressed, somewhat oblique; pericarp very thin, outside almost smooth; seeds 2-4, small, unattached, oval or nearly roundish, very convex on the outer side, hollow and twisted on the inner side.

At Gulgong in the Upper Pliocene formation; C. S. Wilkinson, Esq. 


\section{Plate XVI}
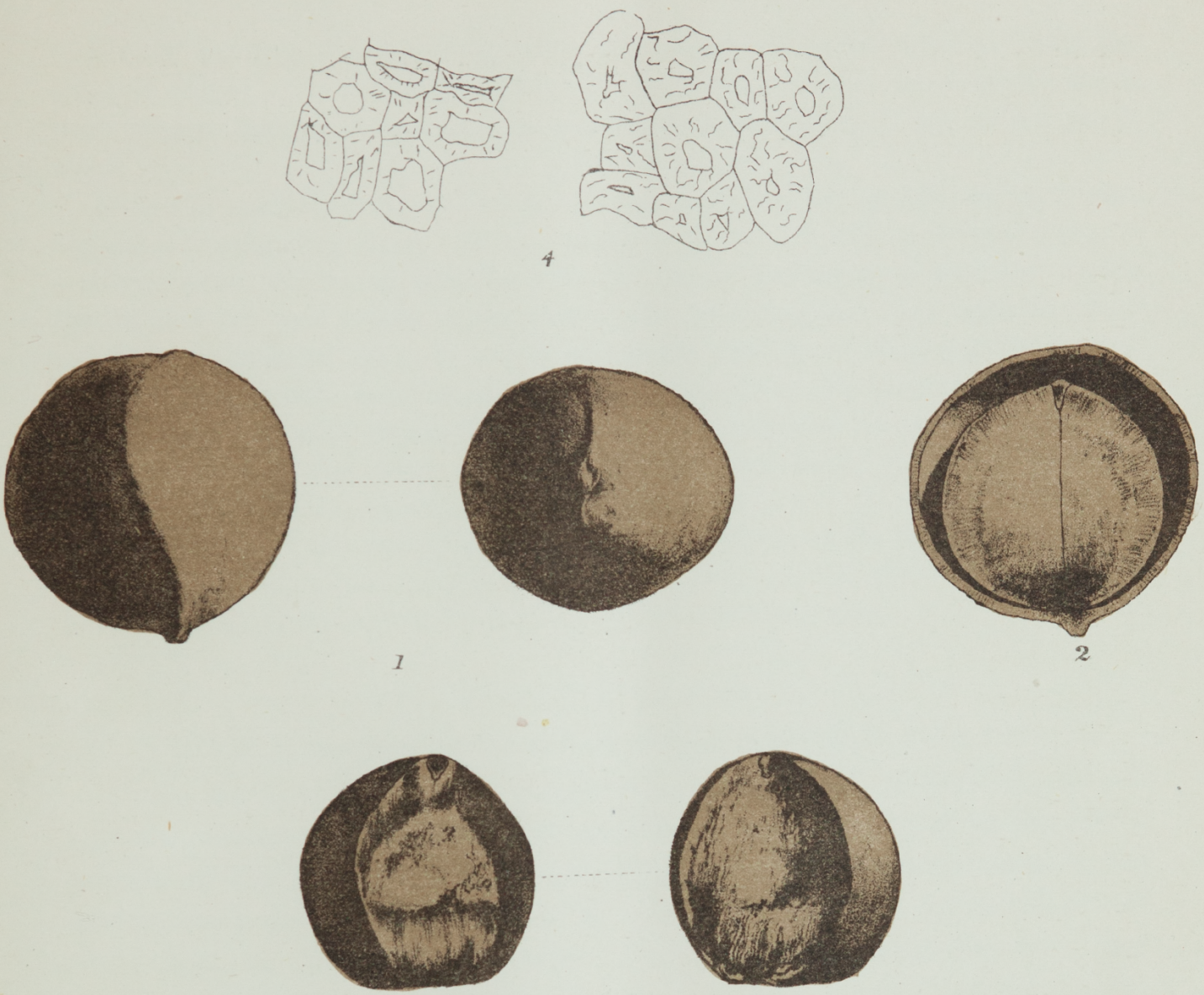

3
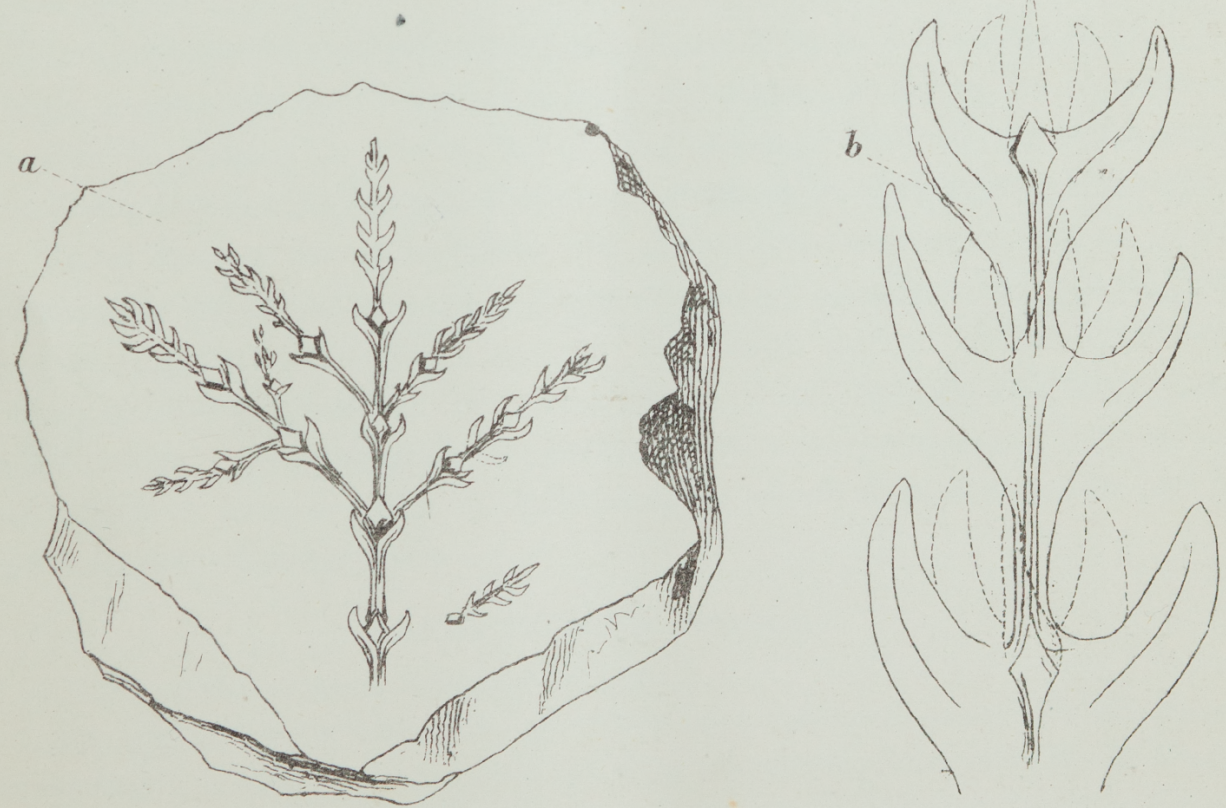

Size of the fruit from $\frac{3}{4}$ to $1 \frac{1}{2}$ inch; the usually slight compression likely the effect of weight on an originally soft fruit; the pericarp outside very slightly rough from minute dots and rugosities, its general thickness about $\frac{1}{2}$ line or not much more.

From the basal cicatrix, indicating an attachment to a hypogynous calyx, a faint angular line extending about half-way upwards on one side, this line terminating in a minute point, indicating possibly a lateral stigma or base of a deciduous style; this lateral line not clearly observable in all the specimens, yet none of them exhibiting a terminal apex; if the interpretation thus given should prove correct, then this fossil would be anomalous among Capparideæ. No traces of placentæ or septa observable, thus likely the seeds originally imbedded in pulp. Number of seeds preserved in the eavity, $2-4$; their length from hardly $\frac{1}{3}$ to nearly $\frac{1}{2}$ inch; their flexure probably the result of exsiccation.

This is one of the many instances, in which the search for precise diagnostics, to define a fossil plant, proves unsatisfactory to a phytographer, accustomed to describe living plants and desirous of doing this conscientiously.

\section{CONCHOCARYON.}

F. v. M. in Reports of the Mining Surveyors and Registrars, December 1878.

Fruit hard, oblique-ovate, considerably compressed, one-celled, almost smooth, dehiscent only along the anterior margin, produced at the lower portion of the back into two acute ridges. Placenta narrow, dorsal in the cavity; its point of attachment to the seed about midway up at the dorsal inner angle of the pericarp. Seed solitary, ovate, turgid, filling the lower part of the cavity, extended at the summit into a flat short triangular appendage.

Name from some resemblance of this fossil fruit to a bivalved shell.

This genus must find its place among Proteaceæ, so far as we at present are able to judge; it approaches in the exterior form of the fruit some Grevilleas, but the pericarp is thicker than usual in that genus, although a few living species occur, in which the fruit-valves are as woody as in all Hakeas; the membranous terminal appendage indicates an affinity to the lastmentioned genus, from which however the lesser degree of the dehiscence of the pericarp removes it; the seed moreover is solitary, smooth and convex on both sides. Regarding fossil plants, the very unsymmetrical form of the fruit offers at once a mark of difference, by which this new genus can be separated from Conchotheca.

\section{Conchocaryon SMithil.}

In drifts of the pliocene period at Gulgong.

I am not certain, whether the as yet unique specimen, on which the genus Conchocaryon is founded, came from the later collections of the Rev. W. B. Clarke 
or from those of Mr. C. S. Wilkinson, or perhaps from some other contributor and from a Victorian locality; but I believe to be correct in giving the above as the place of discovery and in regarding it contemporaneous with the many other fossil fruits, obtained from the auriferous drifts of our own colony.

Concerning the precise age of these fossils, opinions are as yet not quite unanimous. The eminent Nestor-geologist of Australia, whose death we had so recently to deplore, gave utterance to his view in the last (posthumous) edition of the "Sedimentary Formations of New South Wales (Sydney 1878)," p. 91, that they "seemed to belong to the later Pliocene period."

The figures on Plate XVII. give the natural size of the solitary specimen as yet obtained, little less than 1 inch in length. The pericarp is thick in proportion to the cavity, its walls being somewhat more than 1 line in diameter; the surface is but very slightly rough, acute on the anterior, obtuse on the posterior margin, a wide and deep furrow separating the two sharp keels towards the posterior base.

The seed, so far as I have been able to ascertain in an only specimen, is attached on the posterior side of the cavity from a point, where the summit of the nucleus passes into the terminal flat appendage. Nucleus measuring in length about $\frac{1}{4}$ of an inch, evidently longer than the wing of the seed. The circumscription of the genus may have to undergo some slight alteration in reference to the inner structure of the fruit, when more extensive material for dissection shall be at our disposal.

A vast number of supposed proteaceous plants are described by several palæontologists from the tertiary formations of different parts of Europe, but most of these were distinguished generically and specifically from leaves alone, often even without any real evidence of their belonging to this order of plants. Among the comparatively few, safely established as proteaceous from pericarps or seed, I notice none, which bears any close affinity to the particular co-ordinal fossil now rendered known.

By connecting the name of Major the Honorable W. Collard Smith, the Minister of the Mines Department, with this organic remnant of a pre-historic time, I desired to place on public record my grateful acknowledgment of his approval, to continue the distinct series of illustrations of vegetable fossils, commenced and carried on under the auspices of his honorable predecessors.

\section{Explanation of Lithogram.}

Plate XVII.
Plestocapparis leptocelyphis.-Fig. 1, side-views of fruit. Fig. 1a, a smaller variety of the same. Fig. 2, longitudinal section of a fruit. Fig. 3, seeds. All natural size.

CONCHOCARYON SMITHI.-Fig. 4, lateral and dorsal view of a fruit. Fig. 5, longitudinal
. Fig, 6, cellular tissue section of a fruit. Fig. 6 , cellular tissue of the pericarp. Figs. 4-5, natural size ; fig. 6, magni-
fied diametrically 200 times.

\section{Araucaria Jomnstonit.}

F. v. M. in Reports of the Mining Surveyors and Registrars, September 1879.

Branchlets slender, dispersed; leaves very short, narrow- or linear-oblong, convex, slightly acute or rather blunt, not much spreading or almost appressed, fow in each spiral coil; strobilus small, its terminal scales blunt and slightly truncated, the downward succeeding scales attenuated into a very short and narrow acumen. 


\section{Plate XVII}

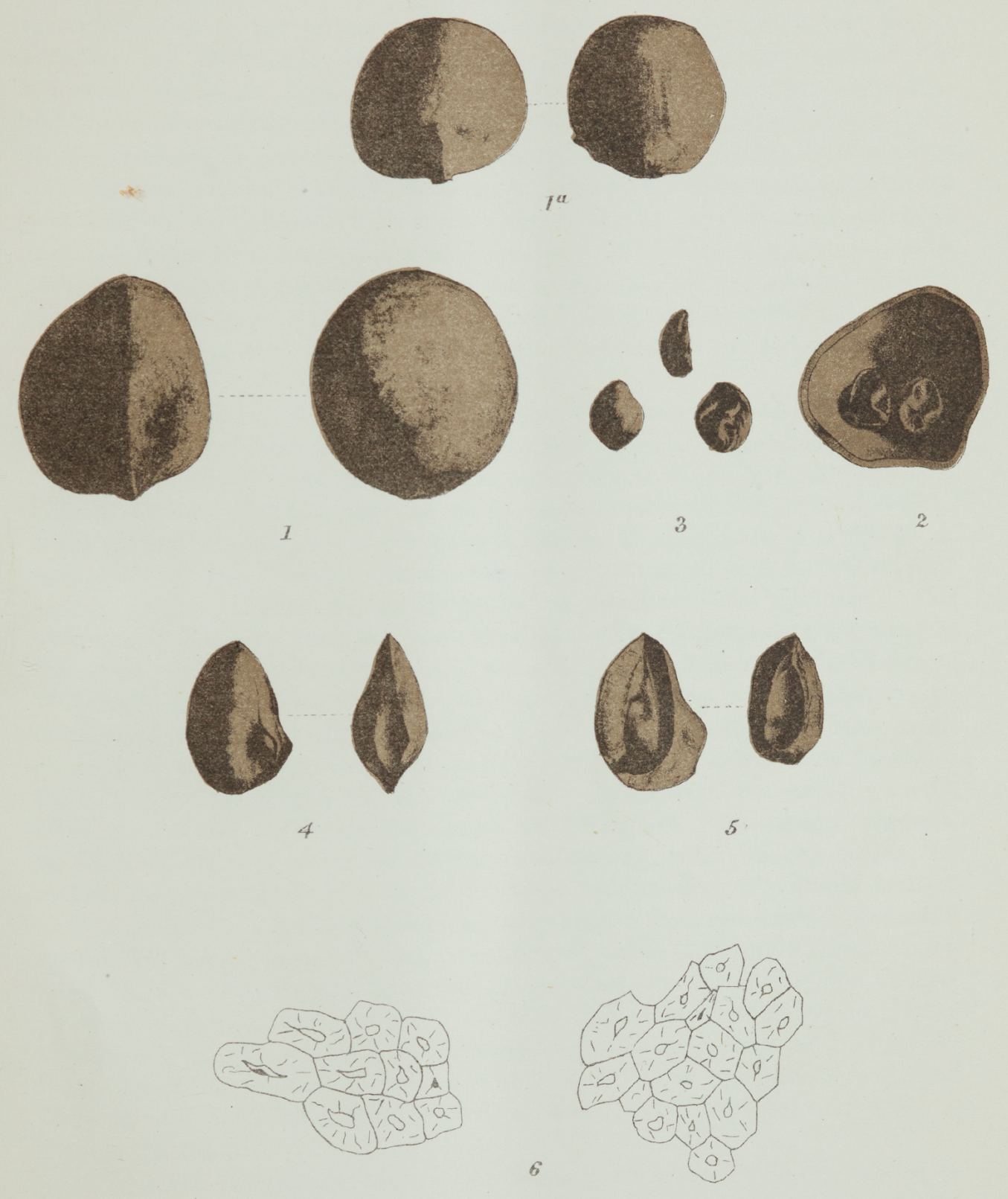



In the Travertin of Geilston-Bay, Tasmania ; Rob. M. Johnston, F.L.S.

The above curt definition circumscribes provisory a new conifer, of which impressions of branchlets and the summit of a fruit-cone were very recently found imbedded in the yellow tertiary freshwater-limestone near Hobart by the assiduous and circumspect amateur-geologist of Launceston, who observed this interesting coniferous fossil associated with fruits of the genera Penteune, Plesiocapparis and Platycoila. Noticing this association with congeneric and even perhaps conspecific types of plants from our Victorian Gold-drifts, I felt justified to admit this new fossil into the series of those, promulgated by the Department of Mines as pertaining to the auriferous drift-strata, although the tree now under consideration may not really be indicative of that formation. Mr. Johnston has argued with great lucidity on the geologic relation of this conspicuous fossil, now after ages for the first time disinterred by his searches; and I shall avail myself of his notes, to render the occurrence of this conifer rightly understood in its palæontologic meaning.

Before proceeding $\mathbf{I}$ wish it to be distinctly understood, that I placed with diffidence and hesitation this conifer of a bygone time in the genus Araucaria, as suggested by Mr. Johnston already. The impression of the solitary fruit-specimen hitherto obtained exhibits only the marks of the apices of the bracteal scales; hence the cardinal character of the genus Araucaria, as acknowledged in the living species of that genus, namely the consolidation of each nutlet with its two bracteal scales, has yet to be traced out for generic confirmation in the new fossil. The shortness of the leaves gives it also a somewhat different aspect, when compared to that of any living Araucaria, reminding rather among fossil plants of the foliage of Walchia, Voltzia, Echinostrobus and Palissya. Furthermore the shortness of the terminating acumen of the fruit-scales is not normal in existing Araucarias, although in A. Balansæ (Brogniart and Gris in nouvelles Archives du Muséum, Paris, VII. p. 206-207, pl. 13) it is also shorter than usual; and certainly in the fossil A. cretacea of France (as figured in Schimper's Paléontologie végétale, pl. LXXVI. 2), the scales are delineated as devoid of an acumen; but as the coalescence of the bracts with the nutlet is not demonstrated, the generic position of that fossil of the chalk-formation seems as yet not free from doubt. But other species of Araucaria have, as fossil, been admitted before in the work above quoted (tome II., 253-254), from fairly preserved fruit-remnants obtained in the oolithic formation of Britain ; yet Carruthers was not fully convinced of their generic conformity and preferred to keep the English fossil species separate as Araucarites, which generic appellation might meanwhile be applied to the Geilston supposed congener also, although Schimper gave to that generic term recently again a different limitation.

If at all a comparison of the new fossil Araucaria with living species is admissible, it must particularly be with $\mathbf{A}$. Cunninghami, from which it differs however in far more slender branchlets with far less leaves of each spiral turn, in the latter not being incurved (and perhaps also never dimorphous), in their remarkable shortness, in their apex being less pointed, and furthermore in much smaller fruits (if what we have hitherto seen of $\mathbf{A}$. Johnstonii represents the fruit 
in an advanced state of growth), with scales extended into a much less elongated awlshaped-linear apex. In speaking here of Araucarias of the present day, it may be incidentally remarked, that the A. Muelleri (Br. and Gr., 1. c. 219, pl. 15), represents the original A. Rulei, as xylographically illustrated by me in Lindley's Gardeners' Chronicle more than 20 years ago, and I may be allowed further to point out passingly, as concerning existing coniferæ, that the genus Belis (from $\beta \varepsilon \lambda o s$ ) well established already in 1807 by Salisbury (in the transactions of the Linnéan Society, VIII., 315-316), should in justice take precedence over Cunninghamia (R. Brown in L. C. Richard's Commentatio de Conifereis et Cycadeis, p. 149, t. 18, anno 1826), the name of the former genus being not more similar to Bellis, than that of Bassia or Brassica to R. Brown's Brassia.

The locality, where this fossil supposed Araucaria was obtained, is to us of classical interest. Already Charles Darwin visited it during the stay of H.M. ship Beagle at Hobart, and it was alluded to by that illustrious naturalist subsequently in his journal p. 448 (as well pointed out by Mr. Johnston) and also in his work on vulcanic islands p. 140 (as quoted by Sir Paul de Strzelecki, from a note of J. Morris, Physical Description of New South Wales and Van Diemen's Land p. 254). The last-named palæontologist moreover figured in Strzelecki's work several of the travertin-fossils from near Hobart, assigning to them a pliocene age (pl. VII. figs. 5-7), the leaf illustrated by fig. 5 representing the most abundant vegetable species in the sediment there according to Mr. Johnston, who however is inclined to consider these organic relics, notwithstanding the close affinity of some of them to forms of the present vegetation, as belonging to the miocene period, a view also taken by Professor McCoy, and to some extent supported by the late Rev. W. B. Clarke. Light on this special subject was thrown also by the late Morton Allport, who concluded from his local observations (Proceedings of the Royal Society of Tasmania, June 1876), that the intrusion and effusion of feldspathic Basalt has covered the travertin-bed, and (as shown also by Mr. Johnston) left to subsequent changes a portion of this freshwater-limestone as a superincumbent stratum, concealing bones of Phalangistæ and Hypsiprymni. Hence, as Mr. Allport puts it, the outflow of Basalt must have taken place earlier than the formation of the diluvium with its marsupial remnants, but must still be regarded of later date than that of the travertin with its vegetable fossils, to which latter now the Araucarian tree is added.

Professor Ulrich, as stated also by Mr. Johnston, considers the Basalt of Geilston-Bay and of similar geologic localities in Tasmania (coeval with what the latter calls the Launceston tertiary bed) identical with what in Victoria is often designated as the older vulcanic formation, which caps those fossiliferous layers belonging to a period, when Spondylostrobus-Cypresses and sapindaceous Phymatocaryon- and Penteune-trees leadingly with other now extinct silvan vegetation luxuriated over extensive portions of at least South-Eastern Australia and over very many parts of the now Tasmanian Island also. Mr. Johnston, with others, confirms, that the rich chocolate-colored soil in Tasmania, as in Victoria, is widely derived from feldspathic Basalt, and further that in auriferous and stanniferous regions it frequently overspreads the diluvial drifts, whereas the Augite-Greenstone, 



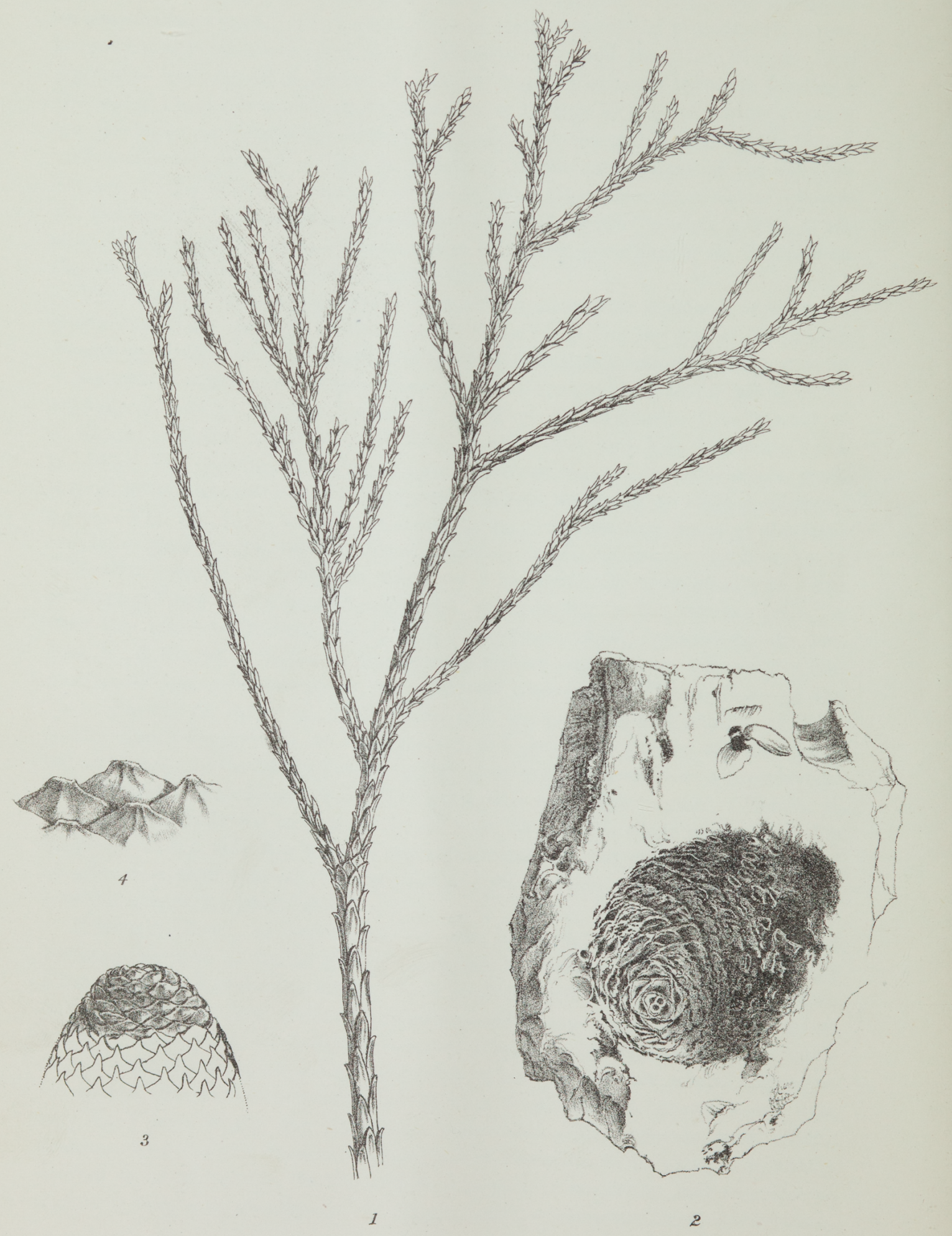


as pointed out by Professor Ulrich, has proved non-auriferous, wherewith often a clue is given for the likely success in operations of gold mining by clear scientific data.

\section{Explanation of Lithogram. \\ Plate XVIII.}

Fig. 1, branch with branchlets, restored from fragmentary impressions. Fig. 2, impression of the upper portion of a strobilus on travertin-stone. Fig. 3 , the same restored to its natural appearance. Fig. 4, some of the upper fruit scales, in situ, much enlarged. Figs. 1-3, natural size.

\section{PLEIOCLINIS.}

F. v. M. in Reports of Mining Surveyors and Registrars, March 1882.

Fruit loculicidal, 7-9- rarely 6-valved, ovate-globular or ovate or rarely depressed-globular, of woody hardness, slightly tubercular-rough outside; valves thick, tardily and partially or often very imperfectly seceding from each other, mostly of permanent coherence towards the base. Free central axis none. Seeds solitary in each cell, usually few or even one only developed in each fruit, occasionally all missing; when well developed completely filling the cavity of their cell and pendent from its summit, oblique-ellipsoid, minutely apiculated, towards the hilum somewhat attenuated, fixed to a very short funicle; membranous appendage none. Raphe dorsal, partially seceding. Testa thin and smooth.

The generic name, composed of $\pi \lambda \varepsilon i o s$, more, and $k \lambda$ vvis, couch, alludes to the comparatively numerous valves, on the cavities of which the seeds are embedded.

\section{Pleiochinis Couchmanit.}

In the middle pliocene drifts, overflown by lava, at Nintingbool and Haddon. The fossil plant, of which as yet the fruit only has become known, is dedicated to Major Couchman, who, as Secretary of the Mines Department of Victoria, has most readily promoted the palæontologic researches initiated by his predecessor. The specimens were mainly obtained through the circumspect assiduity of D. W. Spence, Esq., and are by no means of such wide occurrence as the fruits of Spondylostrobus Smythii, Phymatocaryon Mackayii, Penteune Clarkei and Celyphina MacCoyi. Locally the Pleioclinis fruits pass as "nutmegs" among the miners, so called from some fancied resemblance to the well-known spice-seeds of that name. As indicated in Major Shepherd's accurate lithographic drawings, the length of this fruit varies from hardly half an inch to rather more than one inch; the dehiscence is more definite at the summit than towards the base. Exceptionally a five-valved specimen may occur, this fossil then bearing great resemblance to Penteune trachyclinis, but exhibiting the characteristic narrower and less turgid seeds, which moreover occupy a longer space in the cavities, while besides the valves do not separate so readily. Thus as a genus Pleioclinis is distinguished from Penteune by the plurality of valves already, so far as in our present state of 
knowledge can be judged; but the great constancy of the number of fruit-valves in genera of Sapindacex and allied orders of the now living vegetation of the globe forbids incorporating this new species of fossil fruit in Penteune. Indeed the genus as now established was indicated, when a doubtful species was added to Rhytidotheca, R. pleioclinis (Observ. on new veg. fossils, I. decade, p. 20, pl. VI., fig. 1-4), that plant constituting in reality a second congener of Pleioclinis, which I now would wish to distinguish under the name Pl. Shepherdi, in appreciation of the services, rendered by Major Shepherd's artistic talent in illustrating so many fossil relics. The genus Rhytidotheca, as extended researches from additional material have proved, is to be restricted to Rh. Lynchii solely. The generic characteristic now given of Pleioclinis applies to Pl. Couchmanii mainly, from which $\mathrm{Pl}$. Shepherdi differs in smaller size of fruit, in comparatively thinner valves, in their coherence at both extremities (though their lateral dehiscence is more perfect) and in comparatively narrower seeds.

\section{OCHTHODOCARYON.}

F. v. M. in Annual Report of the Department of Mines of New South Wales, 1878, p. 171, pl. IV., figs. 1-2.

Fruit large, globular or verging into an ovate form, outside very uneven from copious verrucular and scantily ridged prominences, inside smooth; pericarp of considerable thickness and almost of bony hardness. Septa none. Seeds unknown. Generic designation from $\dot{x} \theta \omega \delta \eta s$, warty and кapvov, nut.

As the name implies, this genus of fossil plants approaches in outer verrucular roughness of the fruit to Phymatocaryon, while the large size, the valveless structure and the absence of dissepiments of the fruit bring the genus nearer to Plesiocapparis, from which again the roughness and greater hardness of the pericarp distinguish it. The outward resemblance of the nut to that of Xylocaryon is also very great, but from the cavity no ridgelike protrusions arise interjacent to the lobes of a large seed.

\section{Ochthodocaryon WiLkinsonir.}

In the upper pliocene formation of Gulgong; C. S. Wilkinson, Esq.

Although this conspicuous fossil nut has not yet been found within the territory of the colony of Victoria, it was deemed desirable, to include it in the series of illustrations, explanatory of our pliocene flora, especially as this fossil plant of probably arboreous growth was coeval to the many other trees, the fruits of which have been rendered known through these Decades, and as in all likelihood the Ochthodocaryon will also yet be discovered in Victorian auriferous drifts.

It seems, that as yet no more specimens of this fruit have turned up, than the two delineated on plate IV. of the Report of the New South Wales Mines Department for 1878. Hence the ordinal location of this genus, in our present unacquaintance with the characteristics of the seeds, remains still unsettled. 



\section{Plate XIX}

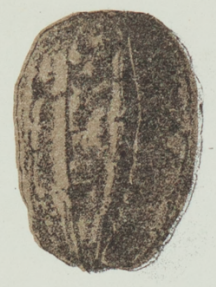

I

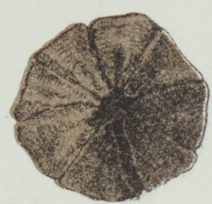

5
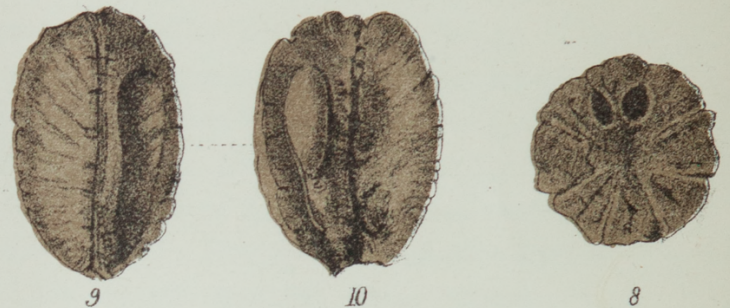

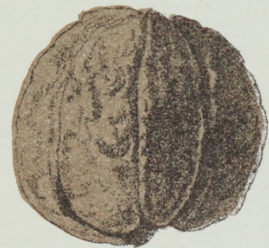

3

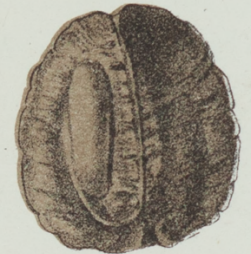

11

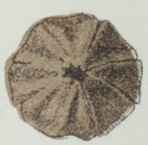

7

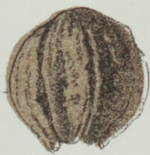

4

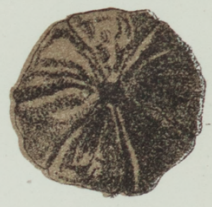

6

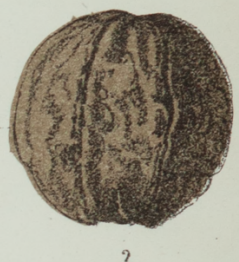

2

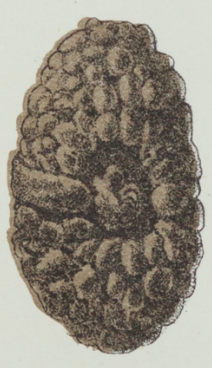

2.3

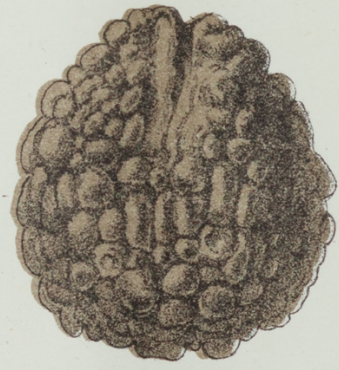

12

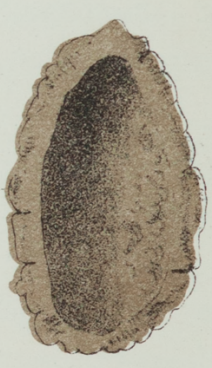

74
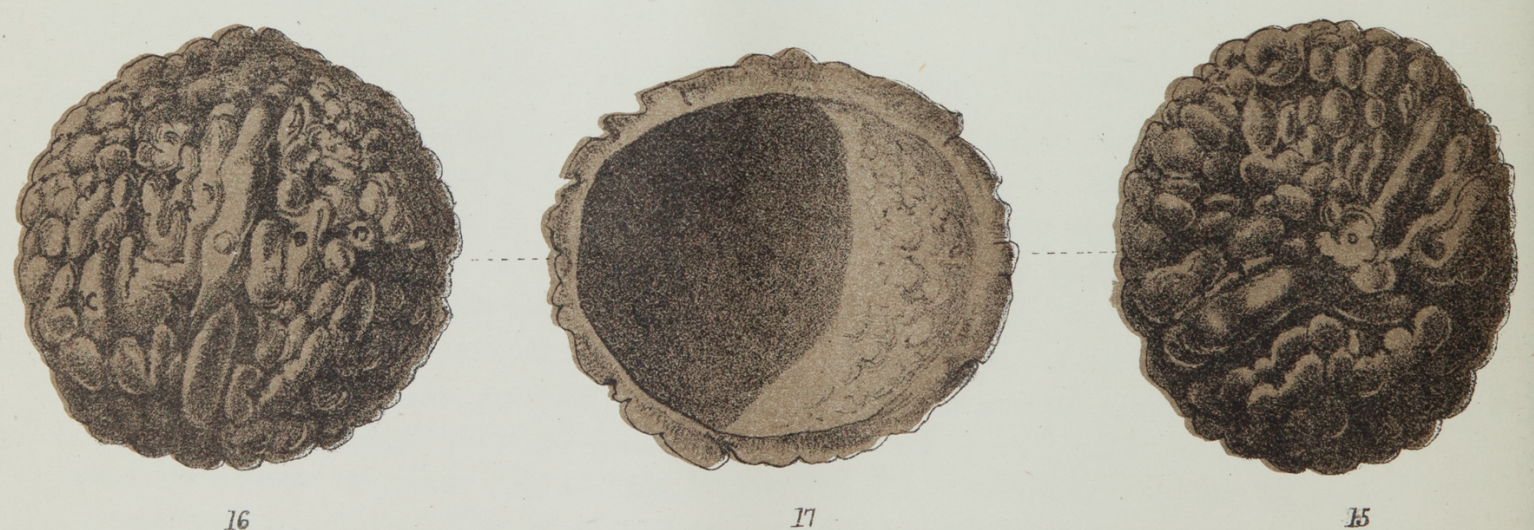

R Shepherd et A.Stopps. Del et Lith 


\section{Explanation of Lithogram.}

\section{Plate XIX.}

Pleiochinis Couchmanir.-Figs. 1-4, side-view of reversed fruits. Fig. 5, fruit seen from above. Figs. 6 and 7 , fruits seen from below. Fig. 8, transverse section of a fruit. Figs. 9-11, longitudinal sections of reversed fruits.

Ochthodocaryon Wilkinsonir.-Figs. 12 and 15, side-view of fruits. Figs. 13 and 16, fruits seen from below. Figs. 14 and 17 , longitudinal section of fruits.

In concluding the carpologic definition of fossils for the second decade of these plants, it will be desirable to place on record, what in the course of the last dozen years through accumulation of larger material has been ascertained in reference to additional characteristics of the fruits hitherto illustrated. Spondylostrobus Smythii; fruit-specimens were collected by Mr. Spence, near Ballarat, quite conically attenuated, the valves proceeding from near the base, ceasing however at two-thirds of the height of the fruit; a six-valved variety occurs of less than one inch measurement, while also forms have been met with considerably larger than any at first illustrated. Celyphina MacCoyi presents occasionally fruits of nearly two inches measurement, and a pericarp of fully half-inch thickness; the attachment of the ovules is parietal; hence it would seem, that no dissepiments are developed evanescent in age. When the Celyphina-fruits are so large and so roundish, as to resemble externally those of Plesiocapparis prisca, a distinctive difference may still be noted in their proportionately thicker pericarp and comparatively smaller cavity. Penteune Clarkei fruits have also been found quite two inches long, and Phymatocaryon Mackayi fruits have likewise been gathered fully one and a half inch long, the latter continuing their characteristic roughness, thus abnormal four-valved forms of either remaining readily distinguishable. Platycoila Sullivani exhibits not always the first noted valvular structure of the fruit, though the described dehiscence seems not to have been accidental. Rhytidotheca Lynchii produces as many as four ovules in one cell ; the well-ripened solitary seeds become at each extremity elongated into a winglike membrane. Conchotheca rotundata seems to have its fruit laterally affixed to a stipes, as is the case with many Grevilleas, the place of communication with the pericarp being near the middle of the posterior side; the well-developed seed completely fills the cavity, is flat-compressed, almost truncate at one extremity and slightly apiculate at the other; the testa is membranous, minutely rough from granular elevations, which are mostly arranged in short lines, giving to the outside of the seeds a pretty appearance. Penteune trachyclinis produces occasionally two seeds in each cell, the upper extremity of the lower seed 
and the lower end of the upper seed truncate. Specimens of Dieune pluriovulata, sent from Lal-Lal by Prof. Krause, show one seed finally filling the cavity of the fruit. Mr. J. Milne Curran, in collecting fruits of Spondylostrobus Smythii, Phymatocaryon Mackayi, Ph. angulare and Penteune Clarkei near Dubbo, has demonstrated, that forests of these trees in pliocene times extended to what forms now the valley of the Upper Macquarie-River. From the matrix, in which fossil fruits of various kinds were embedded near Ballarat, Mr. Spence obtained also detached remnants of leaves, which however could not be traced to any of the particular species of those plants, whose names in these pages originated from carpologic investigations solely.

\section{Spondylostrobus Smythit.}

The huge fossil stems with remarkably light and fissil wood, noticed in the auriferous drifts at Haddon, are assumed by the writer to belong to Spondylostrobus, with the fruits of which this wood is there associated. Professor Ferd. Krause, the accomplished Geologist and Mineralogist to the School of Mines at Ballarat, forwarded chips from a stem, which was upwards of three feet in diameter, where laid free by the drive of a mine. Anatomic examination, as now shown, places the tree, yielding this wood, in the series of Cupressinous Conifers, as defined histologically by Dr. H. R. Gœppert, Director of the Botanic Garden of Breslau, who in his grandly scientific establishment for a long series of years has traced also the connections between the fossil and living species of Coniferæ from arboreta as well as museum-material. In his "Monographie der fossilen Coniferen," issued in 1850, and in his "Revision der Arbeiten ueber die Stæmme der fossilen Coniferen," published last year, he describes the tribe of Cupressinæ xylo-logically as follows : "Margined dots in the tracheidæ, forming simple rows; smaller uniform edgeless dots in the medullary rays ; resin-ducts simple,"-in contrast to Araucarieæ with : "Dots of tracheidæ closely approached in simple or double spiral rows; dots of medullary rays very small and usually edged" (the Pinaceæ, Taxaceæ and Gnetaceæ requiring no allusion on this occasion). We have neither in the locality, where the coniferous stem was unearthed, nor as far as known elsewhere in Australia any fossil cupressinous trees coeval with Spondylostrobus; inasmuch as the conifer from the Travertin of Tasmania belongs to the tribe of Araucarieæ, indeed in all probability to the typical genus Araucaria, and as such it was described and illustrated in the 3rd Quarterly Report of the Department of Mines for 1879. What relation a very similar conifer, placed by Dr. Feistmantel doubtfully into genus Brachyphyllum (Palæontographica 1880, p. 97-99, t. vii. fig. 3-6), may bear to Araucaria Johnstoni, further researches must prove, when well-developed fruits and also the stems of both shall have been discovered. The supposed Brachyphyllum came from a clay-band in an isolated coal-seam of Lithgow-valley, New South Wales. It seems very near to Araucaria and not eongeneric to the genuine Brachyphyllum mamillare (Brogniart) of the oolithic formation in Britain. To the admission of these two fossil species of Coniferæ into Araucaria can be the less 



\section{Plate XX}

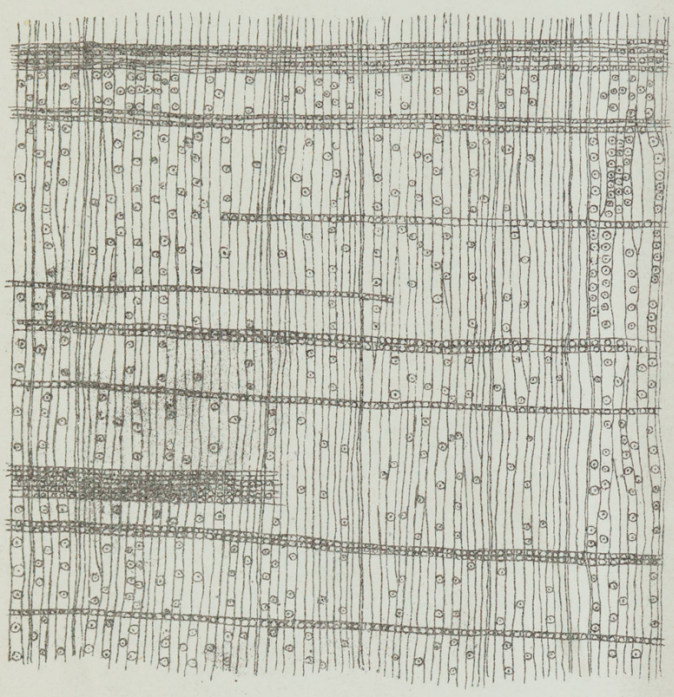

1

$\frac{30}{i}$

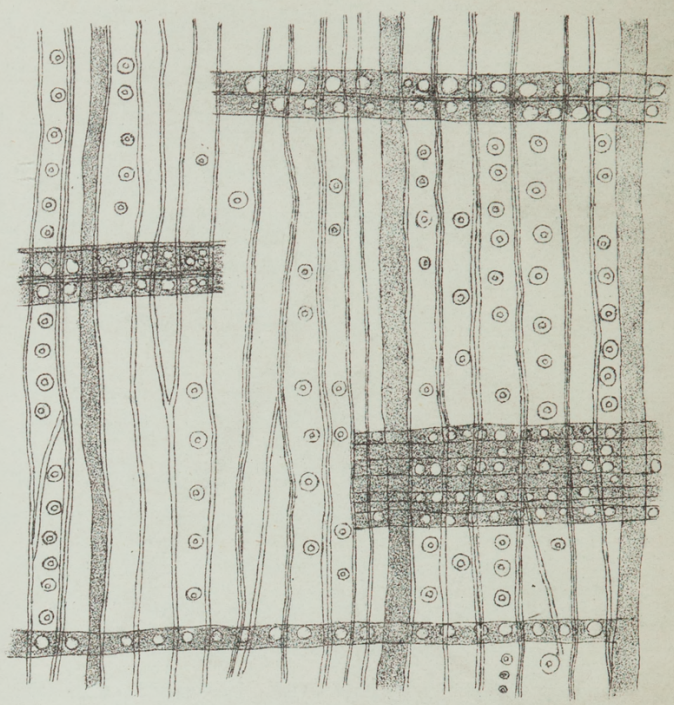

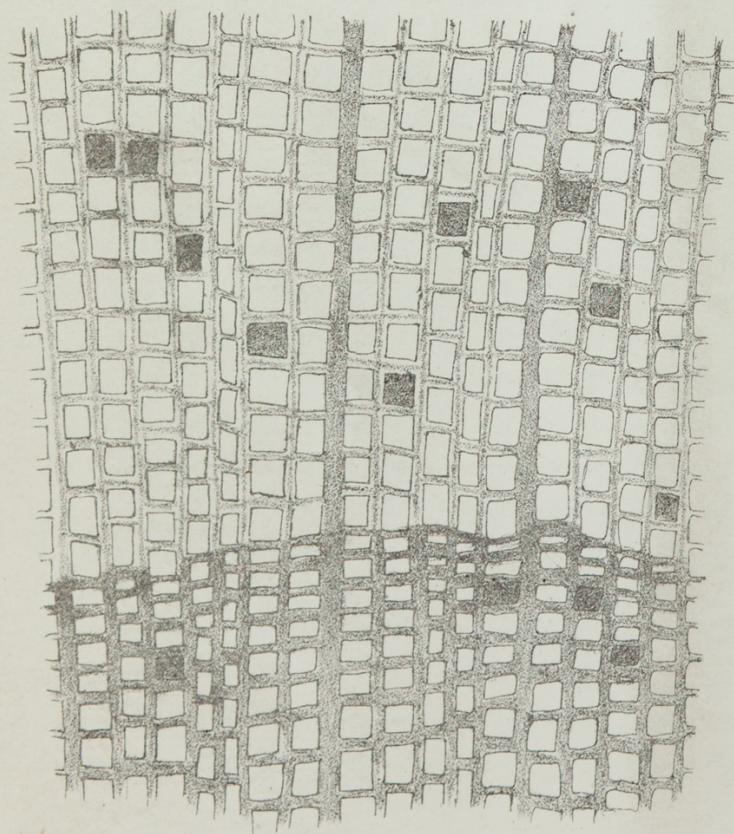

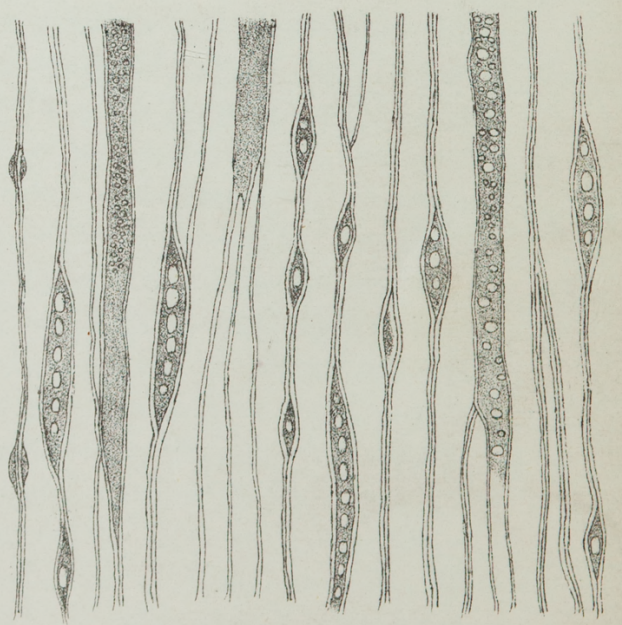


objection, since J. St. Gardner was led by his researches ("Nature," 1880, p. 199-202), to extend the limits formerly assigned palæontographically to that genus, and as Lesquereux has traced true Araucarias to the Triasic, Carruthers to the Jurassic, and lastly Gardner to the eocene epoch.

\section{Explanation of Lithogram.}

\section{Plate XX.}

Spondylostrobus Sмyтнir.-Fig. 1, radial section of aged stem-wood, exhibiting in horizontal lines the medullary rays, and in vertical lines the woody fibres, diametrically 30 times magnified. Fig. 2, radial section, diametrically 120 times magnified, as in the two following sections. Fig. 3, transverse section of wood, exhibiting in regular quadrangular spaces the walls and cavities of woody fibres, in long dark lines the medullary rays, and in scattered dark spots the resin-ducts, the transverse darker shading indicative of the limits between two sets of annual growth. Fig. 4, tangential section of wood, with groups of medullary rays transversely cut, and with vertical lines and spaces of woody fibre. 




\section{CONTENTS.}

PLATE XI.

XTLOCABYON LócKIr.

PI.ATE XII.

Rhytidocaryon WiLKinsonir.

TLATE XIII.

WILKI JUNIA BILAMINATA.

P:ATE XIV.

Tricorlezar yon BaRnaRdr.

1. $A$ ATE XV.

Eisothecaryon semiseptatum (Figs, 1-5).-Phymatocaryon bivalve (Figs, 6-9).Illicites astrocarpa (Figs. 10-14),-Pleiacron elachocarpum (Figs. 15-18).Pentacoila Gulgongensis (Figs. 19-20).

PiATE XVI.

Plestocaptaris megasperma (Figs. 1-4).-Spondylostrobus Smythir (Fig. 5).

P1.iTE XVII.

Plestocatparis leptocelyphis (Fic 1-3).-Conchocakyon Smithil (Figs. 4-6).

PLATE XVIII.

Araucaina Johnstonir.

PLAIE XIX.

Pleioclinis Couchmanil (Figs. 1-11), - Ochthodocaryon Wilkinsonir (Figs. 12-17).

PL.TE $X X$.

Spondxho iabes Smythil. 

